\title{
Fukushima to Fessenheim: France and Germany's Policy Responses to the Fukushima Nuclear Disaster, 11 March to 18 June 2011
}

by

Jennifer Rose Linehan

A thesis submitted to the Faculty of Graduate and Postdoctoral Affairs in partial fulfillment of the requirements for the degree of

\author{
Master of Arts \\ in \\ European, Russian and Eurasian Studies \\ Carleton University \\ Ottawa, Ontario
}

(C) 2013, Jennifer Rose Linehan 
Library and Archives

Canada

Published Heritage

Branch

395 Wellington Street

Ottawa ON K1A ON4

Canada
Bibliothèque et

Archives Canada

Direction du

Patrimoine de l'édition

395 , rue Wellington

Ottawa ON K1A ON4

Canada
Your file Votre référence

ISBN: 978-0-494-94587-2

Our file Notre référence

ISBN: 978-0-494-94587-2
NOTICE:

The author has granted a nonexclusive license allowing Library and Archives Canada to reproduce, publish, archive, preserve, conserve, communicate to the public by telecommunication or on the Internet, loan, distrbute and sell theses worldwide, for commercial or noncommercial purposes, in microform, paper, electronic and/or any other formats.

The author retains copyright ownership and moral rights in this thesis. Neither the thesis nor substantial extracts from it may be printed or otherwise reproduced without the author's permission.
AVIS:

L'auteur a accordé une licence non exclusive permettant à la Bibliothèque et Archives Canada de reproduire, publier, archiver, sauvegarder, conserver, transmettre au public par télécommunication ou par l'Internet, prêter, distribuer et vendre des thèses partout dans le monde, à des fins commerciales ou autres, sur support microforme, papier, électronique et/ou autres formats.

L'auteur conserve la propriété du droit d'auteur et des droits moraux qui protege cette thèse. $\mathrm{Ni}$ la thèse ni des extraits substantiels de celle-ci ne doivent être imprimés ou autrement reproduits sans son autorisation.
In compliance with the Canadian Privacy Act some supporting forms may have been removed from this thesis.

While these forms may be included in the document page count, their removal does not represent any loss of content from the thesis.
Conformément à la loi canadienne sur la protection de la vie privée, quelques formulaires secondaires ont été enlevés de cette thèse.

Bien que ces formulaires aient inclus dans la pagination, il n'y aura aucun contenu manquant. 


\begin{abstract}
In response to the 2011 Fukushima nuclear disaster in Japan, France ordered stress tests of its nuclear plants while Germany announced its nuclear exit by 2022. Given that both countries benefitted from nuclear energy with a relatively low risk of a disaster, this divergence is puzzling. Yet France and Germany's reactions were not ad hoc reactions; they were shaped by their post-war experiences and previous anti-nuclear mobilizations. Fukushima merely offered a political opportunity for the effective vocalization of antinuclear dissent, and ultimately the permeability of governing institutions determined each country's response. In order to explore this argument, this paper will examine the issue's coverage predominately within one French newspaper, Le Monde, and one German newspaper, Süddeutsche Zeitung, from 11 March to 18 June 2011 to gain insight of contemporary political opportunities and elite consensus as well as how meaning was being constructed and consumed by the public on this issue.
\end{abstract}




\section{Acknowledgements}

I would like to express my gratitude to my supervisor, Dr. Joan DeBardeleben, whose expertise and guidance considerably enriched my graduate experience. Her patience and understanding during the completion of this thesis eased a sometimes stressful endeavour and was very much appreciated.

I would also like to thank my family and friends for their support and encouragement during the completion of this thesis (particularly for when this support was expressed through chocolate). 


\section{Table of Contents}

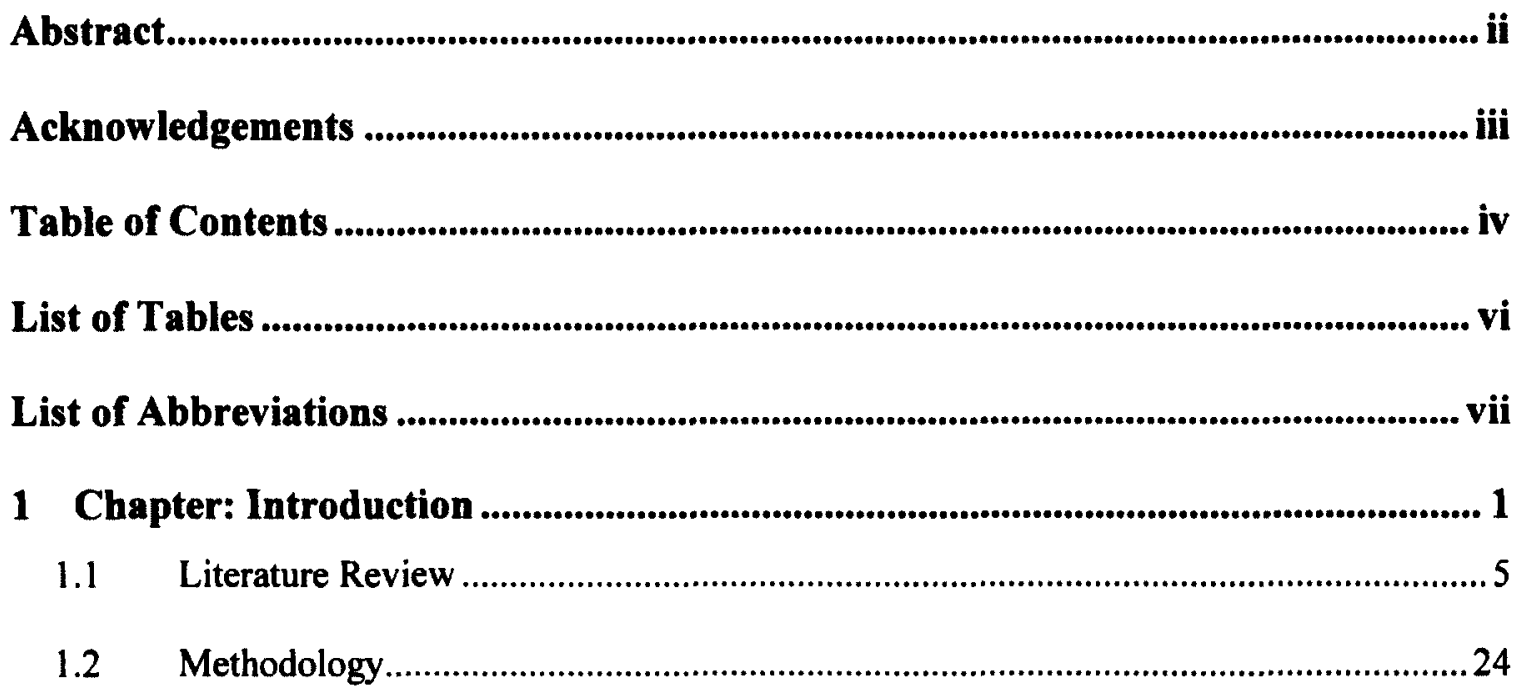

2 Chapter: Contextualizing Reactions to the Fukushima Disaster ............................. 32

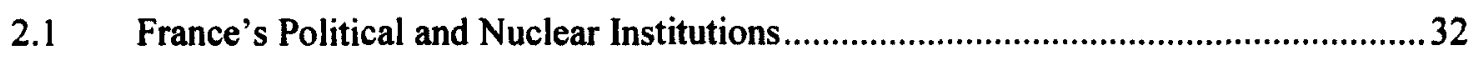

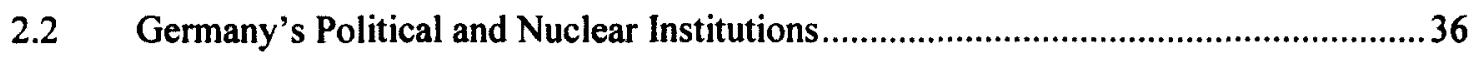

2.3 Public Attitudes Toward Nuclear Energy ............................................................. 38

2.4 Setting the Stage for France and Germany's Fukushima Reactions............................51

3 Chapter: French and German Media Coverage, 11 March - 18 June.................. 53

3.1 Fukushima Media Coverage and Immediate State Reactions .....................................54

3.2 Transparency and Democracy Concerns: Nuclear Industry and Government as 'Too

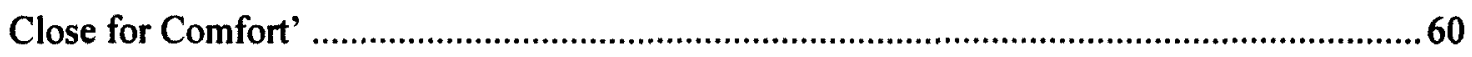

3.2.1 French Concerns about National Government and Industry Collusion ..................61

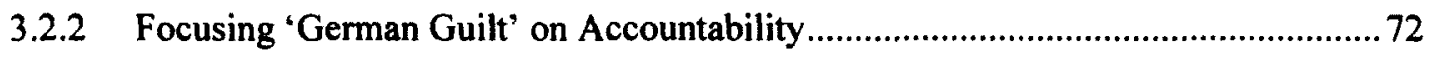

3.2.3 Government-Public and State-Industry Relationships Conceming Nuclear Energy 80

3.3 French Frames: Energy Independence, Progress, and Cheap Electricity ...................83

3.3.1 Institutional Structure and the French Government's Response ..........................96

3.4 German Political Opportunities: 2011 as 'Super' Election Year.................................99 


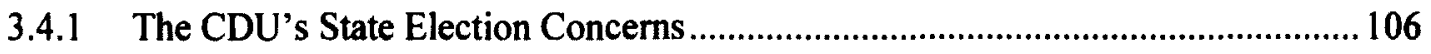

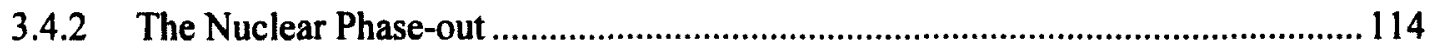

3.4.3 Coverage by Berliner Zeitung and Die Welt....................................................... 116

3.4.4 Germany's Response and the Influence of Elections......................................... 119

3.5 Elite Consensus: Reversals of Trends in France and Germany ............................... 123

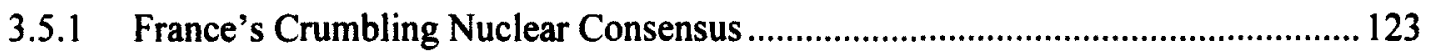

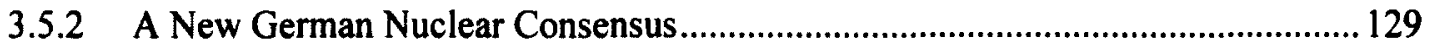

3.5.3 Changing Perspectives of the French and German Political Elite......................... 134

3.6 Fukushima Divides: France, Germany, and European Reactions ..........................136

3.6.1 French Media and Political Commentary on Germany's Fukushima Response ....137

3.6.2 German Media and Political Commentary on France's Continued Nuclear Path.. 140

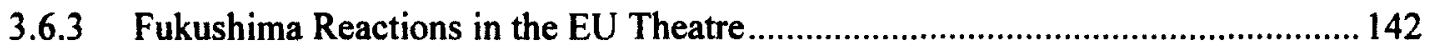

3.6.4 Contextualizing Fukushima Reactions .............................................................. 147

4 Chapter: Explaining Diverging Reactions to the Fukushima Disaster............... 149

Bibliography ................................................................................................................ 153 


\section{List of Tables}

Table 1 Summary of Results from Eurobarometer 262, 271, and 324......................... 39

Table 2 Articles in Le Monde from 11 March to 18 June 2011 .................................... 54

Table 3 Articles in Süddeutsche Zeitung from 11 March to 18 June 2011 ......................55

Table 4 Articles in Supporting Sources from 11 March to 18 June 2011.......................56 


\section{List of Abbreviations}

Autorité de sûreté nucléaire (ASN)

Nuclear Safety Authority

Christian Democrats (CDU)

Commissariat à l'énergie atomique (CEA)

Electricité de France (EDF)

Europe Écologie - Les Verts (EELV)

Europe Ecology - The Greens

European Pressurized Reactor (EPR)

European Union (EU)

Free Democratic Party (FDP)

Front national (FN)

National Front (FN)

Gross Domestic Product (GDP)

International Atomic Energy Agency (IAEA)

International Nuclear Event Scale (INES)

Organisation for Economic Co-operation and Development (OECD)

Parti socialiste (PS)

Socialist Party (PS)

Social Democratic Party (SPD)

Tokyo Electric Power Company (TEPCO)

Union pour un mouvement populaire (UMP)

Union for a Popular Movement

World Health Organization (WHO)

World War II (WWII) 


\section{Chapter: Introduction}

Identifying factors that lead to political change is a daunting task. In modern democracies, interests collude and collide in a milieu of economic, cultural, and political complexity. Determining how and why some of these interests are, and conversely are not, able to manifest change within the political environment means navigating these interconnected factors to try to determine which ones wield the greatest influence. Examining political change becomes particularly interesting when a single policy issue is able to enact significant change to the political status quo. For some states, nuclear energy has proven to be such an issue.

On 11 March 2011, a 9.0 earthquake shook the eastern coast of Japan and caused a massive tsunami. This earthquake and accompanying tsunami caused immense destruction and loss of life. However, it also triggered the worst nuclear disaster since the Chernobyl meltdown in 1986 at the Fukushima Daiichi nuclear power plant, resulting in the release of a significant amount of radioactive material. While the Fukushima nuclear disaster and its implications for nuclear safety were concerning to all, the discussion was particularly heated in Europe due to the persistent memory of Chernobyl. Most European states committed to safety assessments, but France and Germany represented opposing reactions to the Fukushima disaster. France, which relies on nuclear energy for the majority of its energy needs and whose nuclear industry is significant in terms of its gross domestic product (GDP), called for minimal safety assessments following the disaster. In contrast, the public backlash in neighbouring Germany was surprisingly intense with the politically vulnerable government backtracking on previous commitments to announce that all German nuclear plants would be closed by 2022. Many French ministers publicly 
criticized the German decision, perhaps fearing that this public sentiment could spread to France. They encouraged Germany to reconsider, as Prime Minister François Fillon insisted that there was no way the European Union (EU) could meet its emissions targets without nuclear energy.

The likelihood of a similar nuclear accident in France and Germany is unclear, but the more pressing question is identifying the factors that contributed to France and Germany's divergent responses to this disaster. From an economic perspective at least, Germany's choice to withdraw from nuclear energy while France chose to maintain the status quo is perplexing; both France and Germany were avid producers and consumers of nuclear energy, gaining significant economic benefits from the industry. From another perspective, both France and Germany are democracies who are beholden to their public in their policymaking; one would assume that each of their public's attitudes towards nuclear energy would reflect their respective government's policy. However, public opinion surveys prior to the disaster suggested that both the French and German public wanted to reduce their reliance on nuclear energy and thought that its risks outweighed its benefits. Furthermore, the French anti-nuclear movement was one of the earliest to mobilize and sustained resistance throughout the 1970s. Yet despite the French public's attitudes or actions, the French government continued its support of nuclear energy.

In short, France and Germany's policy reactions were not ad hoc reactions; while this paper weighs ideas of political opportunities, elite consensus, and public opinion heavily as explanatory variables, these variables were formed through each state's postwar experiences and their institutions. As Gamson and Modigliani note, "Nuclear power, like every policy issue, has a culture. There is an ongoing discourse that evolves and 
changes over time, providing interpretations and meanings for relevant events." This paper therefore advances two main arguments. The first is that there must be both a framing of the issue as well as a political opportunity for the issue to become manifest in policy. Germany's previous history with anti-nuclear mobilizations provided a ready antinuclear framing of the issue that was able to influence political change arising from the Fukushima political opportunity occurring during a time of several state elections. In the case of France, the decimation of its anti-nuclear movement after 1981 meant that the French did not have such a ready anti-nuclear framing to take advantage of the Fukushima political opportunity and France's centralized structure meant that only presidential elections (a year away at the time) would have presented a meaningful opportunity for political change. The second main argument is that, if framing has taken place and there is a political opportunity, a policy change is more likely to take place if there is diverging opinion amongst the political elite and public opinion is supportive of the change. Germany already had an anti-nuclear frame in place to take advantage of the Fukushima disaster, and Germany's response was amplified by political party divisions on nuclear energy and growing public hostility towards the technology. Conversely, not only did France not have an anti-nuclear framing in place, but the Fukushima disaster also occurred at a time when all political parties were firmly in favour of nuclear energy despite the fact that a majority of the public was not supportive of nuclear energy. Therefore, the variables under study for each country are historical experience, political opportunities, public opinion, and elite consensus. Interestingly however, the elite

\footnotetext{
${ }^{1}$ William A. Gamson and Andre Modigliani, "Media Discourse and Public Opinion on Nuclear Power: A Constructionist Approach," American Journal of Sociology 95, no. 1 (Jul., 1989), 1-2.
} 
consensus in France began to disintegrate throughout the period of study while the German elite consensus began to build. This suggests that historical experience and political opportunities are the determining factors in each country's response, with elite consensus and public opinion playing a mitigating role through aiding the framing of the issue.

In order to explore these variables as applied to France and Germany's reactions, this paper will examine the historical experiences of each country through a literature review before reviewing one French newspaper (Le Monde) and one German newspaper's (Süddeutsche Zeitung) coverage of the issue from 11 March to 18 June 2011 to analyze the other variables. This extensive media analysis will be supplemented by also considering coverage by the French newspapers Le Figaro and Libération as well as the German newspapers Berliner Zeitung and Die Welt. This date range was chosen to encompass the day of the Fukushima disaster (11 March 2011) to the day after a joint press conference between French President Nicholas Sarkozy and German Chancellor Angela Merkel (18 June 2011). This newspaper analysis was chosen as it provides a way of documenting each state's political opportunities and elite consensus (or conflict as it were), while also providing a glimpse of how meaning was being constructed and consumed by the public in reference to the Fukushima disaster. ${ }^{2}$ As the period of study was less than two years ago from the time of writing, formal post-Fukushima Eurobarometer studies are not yet available to compare public opinion over time. Therefore, using the assumption that media discourse can both reflect and produce

\footnotetext{
${ }^{2}$ While there are certainly other methods that may be more helpful in measuring some of these variables, a media analysis presented a way to examine all of the key variables that previous literature had identified as important.
} 
meaning construction, this paper seeks to analyze the media 'frames' or 'packages' relayed in these two newspapers concerning Fukushima to capture how public opinion was forming in each country during this time.

With this aim in mind, the remainder of this chapter will review the past literature on each country's anti-nuclear movements and reactions to nuclear crises through a historical lens before presenting this paper's methodological approach. The following chapter will present each country's context and public attitudes towards nuclear energy prior to the Fukushima disaster. The next chapter will provide a media analysis using five key themes with the final chapter providing a concluding summary.

\subsection{Literature Review}

As mentioned in the introduction, this paper will advance the argument that both a framing of an issue as well as a political opportunity is necessary for the issue to become manifest in policy. As applied to the nuclear issue, this 'framing' largely occurred through previous anti-nuclear mobilizations that constructed and publicized an understanding of nuclear energy with historical and cultural considerations of each country's experiences. Both France and Germany had dealt with comparable political pressure from nuclear protests in the past yet Germany continued to be the most responsive to this dissent. This can be demonstrated in both countries' approach to Fessenheim, a French nuclear reactor on the German border. Interestingly, Fessenheim shares several similarities with the Fukushima plant - they were built in the same year, use the same technology, and are on seismically active zones. ${ }^{3}$ Parallel to their

\footnotetext{
${ }^{3}$ Michael Kläsgen, "Zweifelnde Franzosen; Die Mehrheit wurde gern aus der Atomkraft aussteigen. Wenn sie nur nicht so billig ware," Süddeutsche Zeitung, 16 April 2011, Factiva.
} 
Fukushima reactions, French authorities wished to extend the plant's lifetime while German activists campaigned to close it.

In the literature, the term 'framing' refers to the work of meaning construction or signification. ${ }^{4}$ Benford and Snow are interested in examining the role of social movements in the construction of meaning and collective action frames, or in other words, "the struggle over the production of mobilizing and countermobilizing ideas and meanings." ${ }^{5}$ Thus, social movements are not "merely...carriers of extant ideas and meanings that grow automatically out of structural arrangements, unanticipated events, or existing ideologies." ${ }^{6}$ Instead, these social movements act as signifying agents who both produce and maintain constructions of meaning for others. In this perspective, social movements are deeply involved in the "the politics of signification," along with other constructors of meaning such as the government and media. ${ }^{7}$ Nor do social movements operate in a vacuum; they receive existing cultural narratives and meanings while actively producing new ones. ${ }^{8}$

In their analysis of American public opinion and media discourse of nuclear energy in the post-war period, Gamson and Modigliani argue that there are competing 'packages' of meaning for every policy issue; "indeed, one can view policy issues as, in

\footnotetext{
${ }^{4}$ Robert D. Benford and David A. Snow, "Framing Processes and Social Movements: An Overview and Assessment," Annual Review of Sociology 26 (2000), 614.

s Benford and Snow, "Framing Processes and Social Movements," 613.

${ }^{6}$ Ibid., 613.

${ }^{7}$ Ibid., 613.

${ }^{8}$ Ibid., 629.
} 
part, a symbolic contest over which interpretation will prevail." Gamson and Modigliani identify several such packages that chronicle the struggle to control the public narrative on nuclear energy over time: 'nuclear dualism,' 'progress,' 'energy independence,' 'soft paths,' 'public accountability,' 'not cost effective,' 'runaway,' and 'devil's bargain., 10 While crafted in response to the American experience, these packages are also applicable to the French and German post-war experience. Each package had a dominant presence at different times, but they remain present throughout each state's history as "[p]ackages ebb and flow in prominence and are constantly revised and updated to accommodate new events." This overview of relevant literature will thus be organized chronically, using the dominant packages of the time.

Both France and Germany emerged from World War II (WWII) in disarray but within the following two decades, they began to develop their own national nuclear industries. France got an early start in 1948, while Germany began later in 1962; however, both reached a high capacity for nuclear energy production relatively quickly due to their high energy demand. At this time, similarly to the American case, the dominant package was the idea of 'nuclear dualism.' This package was dominant in both the French and German cases during approximately the same time as the American case (1945-60), and promoted an understanding of the horrific potential of nuclear weapons while trying to co-opt its potential to create a better world. As Gamson and Modigliani describe the package, "The dominant metaphor is a road that branches into two

\footnotetext{
9 Gamson and Modigliani, "Media Discourse and Public Opinion on Nuclear Power," 2.

${ }^{10}$ Ibid., 2.

${ }^{11}$ Ibid., 2.
} 
alternative paths - one leading to the development of weapons of destruction, the other to the eradication of human misery." 12

The issue of nuclear energy itself causes difficulty for public opinion due to its wartime origins. For some, the civilian and military applications of nuclear energy are inseparable; "[n]uclear power is above all a symbol associated with death and war, and this is what drives the nuclear debate. Indeed the power of this symbol is the main force maintaining the unity of the antinuclear movement." ${ }^{13}$ The first use of nuclear energy was the atomic bombs used on Hiroshima and Nagasaki during WWII, so nuclear energy's history began with an act of warfare. The continued environmental and health effects in both these cities further underscored the devastating potential of this technology. In deciding to implement a civilian nuclear energy program, proponents engaged in an active rebranding exercise to dissociate the civilian program from its military counterpart. For example, 'atomic' power shifted to 'nuclear' power in the late $1950 \mathrm{~s} .{ }^{14}$ More recently, the term nuclear 'energy' instead of 'power' appears to be used more often, perhaps in an attempt to link it more to the civilian program and green energy campaigns. Nelkin and Pollak further explain that: "Nuclear industrial areas became "parks," and accidents became "incidents." German official documents used the concept Störfall (irregularity) rather than Unfall (accident)." 15 This rebranding is striking because France and Germany do not have the same nuclear weapon capacity as Germany was

\footnotetext{
${ }^{12}$ Gamson and Modigliani, "Media Discourse and Public Opinion on Nuclear Power," 13.

${ }^{13}$ Dorothy Nelkin and Michael Pollak, The Atom Besieged: Extraparliamentary Dissent in France and Germany (Cambridge, Massachusetts: MIT Press, 1981), 141.

${ }^{14}$ Nelkin and Pollak, The Atom Besieged, 141.

${ }^{15}$ Ibid., 141.
} 
barred from possessing nuclear weapons after WWII, but this strategy was still considered necessary in Germany.

The 1960s were a period of significant growth for the civilian nuclear energy industry in both France and Germany, and marked the dominance of the 'progress' package in these countries. This largely pro-nuclear package refers to the belief that human civilization will continue to advance through its "commitment to technological development and economic growth." France, who celebrated its post-war technical prowess as a 'nation of engineers.'

The relatively calm period of nuclear expansion ended abruptly in the early 1970s. The energy crisis of 1973 marked an intrinsic change within states' approach to energy policy. Skyrocketing fuel prices meant that states could no longer fuel their economic growth and in fact, these prices triggered a severe recession. Therefore, securing national energy supplies became a priority for every state. This marked the emergence of the 'energy independence' package, which became an important French narrative and continued to be strongly embraced by the French government throughout the Fukushima crisis. In 1974, the French government announced a huge expansion of its nuclear program, the Messmer Plan, to respond to the oil crisis. ${ }^{17}$ Similarly, the German government planned a huge expansion in the Rhine Valley between 1970 and 1985 that would effectively increase its nuclear power potential 13-fold (from 2,590 to 34,740

\footnotetext{
${ }^{16}$ Gamson and Modigliani, "Media Discourse and Public Opinion on Nuclear Power," 4.

${ }^{17}$ James M. Jasper, Nuclear Politics: Energy and the State in the United States, Sweden, and France (Princeton: Princeton University Press, 1990), 155.
} 
$\mathrm{Mw}){ }^{18}$ Jasper notes that this period after the oil crisis marked a change in the control of nuclear policy from bureaucrats and engineers to the political executive. ${ }^{19}$

Yet within this governmental drive for energy security, a new public anti-nuclear discourse was emerging about the environment and sustainable growth. As Joppke notes, "The key word was 'limits' - to growth, resource exploitation, and progress." ${ }^{20}$ This marked the emergence of the anti-nuclear package 'soft steps.' Gamson and Modigliani describe this package as a call to "change [society's] way of life to conserve energy as much as possible and to develop sources of energy that are ecologically safe and renewable, and that lend themselves to decentralized production - for example, sun, wind, and water. ${ }^{21}$ This package was certainly felt throughout the French and German environmental movement, but they varied in their success in trying to mobilize the public and create political change with this narrative. 'Soft steps' made a lasting impact on the German anti-nuclear movement and this package continues to be referenced to the present day.

While the French government was easily able to dismiss early activists as 'irrational' through the promotion of its 'progress' package, its response started to shift in early 1975 when 400 scientists circulated a petition, the "Appel des 400 ", that was widely

\footnotetext{
${ }^{18}$ Nelkin and Pollak, The Atom Besieged, 60.

${ }^{19}$ Jasper, Nuclear Politics, 175.

${ }^{20}$ Christian Joppke, "Social Movements during Cycles of Issue Attention: The Decline of the AntiNuclear Energy Movements in West Germany and the USA," British Journal of Sociology 42, no. 1 (Mar., 1991), 46.

${ }^{21}$ Gamson and Modigliani, "Media Discourse and Public Opinion on Nuclear Power," 16.
} 
publicized and confirmed the existence of more widespread public discontent. ${ }^{22}$ In response, the French government implemented the Ornano Plan as a kind of public relations attempt to convert disbelievers with more details of the nuclear program. The government also allowed an assembly debate on nuclear energy in May 1975, and this was to be followed by regional assembly debates. However, the public understood that these actions were merely 'going through the motions' without any real opportunity to change France's nuclear direction so opposition continued unabated. ${ }^{23}$ In the German case, public opposition was fierce after 1972, effectively curtailing previous government plans for the Rhine Valley expansion. Activists successfully stopped the construction of the Wyhl plant in 1975 through court action and, in 1976 and 1977, several thousand demonstrators protested at the Brokdorf, Grohnde, and Kalkar plants, prompting violent clashes with police but also court decisions that essentially immobilized the development of the nuclear power program. ${ }^{24}$ Despite opposition, the second oil crisis in 1979 prompted both the French and German governments to pursue their nuclear plans; for example, 11 of Germany's 17 plants in 2011 went online after 1980, although some of these were commissioned previously. Furthermore, the French anti-nuclear movement threw their hopes behind the Parti socialiste's (PS) victory in the 1981 presidential election; however, the PS ultimately decided not to pursue a reform of the nuclear

\footnotetext{
${ }^{22}$ Nelkin and Pollak, The Atom Besieged, 59.

${ }^{23}$ Jasper, Nuclear Politics, 171.

${ }^{24}$ Nelkin and Pollak, The Atom Besieged, 3.
} 
program, which led to the decline of the anti-nuclear movement to such an extent that it could not effectively respond to the Chernobyl disaster. ${ }^{25}$

This period also marked the emergence of the 'public accountability' package.

Gamson and Modigliani describe this package as populist as it decries:

...the organization of nuclear production by profit-making corporations, which minimizes accountability and control by the public. The nuclear industry has used its political and economic power to undermine the serious exploration of energy alternatives. Public officials, who are supposed to monitor the activities of the industry, are all too often captives of it. They function more to protect the industry than to protect the public. ${ }^{26}$

This issue had been latent in the public and media discourse for quite some time. Nelkin and Pollak argued that the depoliticization of nuclear power was a major issue as, despite the social, economic, and political significance of nuclear expansion, political institutions were barely involved in the decision-making process. ${ }^{27}$ They attribute the decision of French and German political representatives and institutions to limit their representative role in nuclear policy to the technical specificity of the issue and that the control of this technical expertise resided in the bureaucracy and nuclear industry itself. ${ }^{28}$ They note that both countries' anti-nuclear movements arose out of a period of great economic change, resulting in changes arising out of urbanization migrations and agricultural disruptions as well as an expanding group of educated and skilled citizens with changed political expectations and values. ${ }^{29}$ However, traditional outlets for these expectations -

\footnotetext{
${ }^{25}$ Nelkin and Pollak, The Atom Besieged, 196.

${ }^{26}$ Gamson and Modigliani, "Media Discourse and Public Opinion on Nuclear Power," 16.

${ }^{27}$ Nelkin and Pollak, The Atom Besieged, 37

${ }^{28}$ Ibid., 52.

${ }^{29}$ Ibid., 105.
} 
parliament, political parties, and unions - were unable to provide meaningful political mediation due to the perceived technical monopoly governing nuclear energy policy. ${ }^{30}$ Protesters consistently incorporated the idea of transparency and democracy into their anti-nuclear rhetoric, an idea that was underscored by the fact that, prior to the entry of 'Green' parties into the political system, no political party represented this pervasive view that was held by a significant portion of the population. Political parties' reticence to engage in the nuclear debate thus reinforced its extraparliamentary arena. ${ }^{31}$

In terms of the transparency and democracy arguments surrounding the development of nuclear policy, Nelkin and Pollak refrain from dramatics to instead emphasize:

The contrast between the nuclear information policies in France and Germany reflects different concepts of democracy: the French elitist information model corresponds to a style of policy-making that derives democratic legitimation from electoral majorities; the German participatory model corresponds to its cooperative policy-making process, in which democratic legitimation proceeds through a consensus among major social forces. ${ }^{32}$

However, they do affirm that both governments' approaches to consultation did affect the scale of dissent. While the French consultation process made it clear that the government would continue the nuclear program regardless, the German government's insistence that the citizens' dialogue could generate new options despite its intention to implement the

\footnotetext{
${ }^{30}$ Nelkin and Pollak, The Atom Besieged, 105.

${ }^{31}$ Ibid., 37.

${ }^{32}$ Ibid., 173.
} 
nuclear program had the appearance of hypocrisy and contributed to public dissent. ${ }^{33}$ This hypocrisy legitimated critics' comments about a lack of transparency.

In a later article, Nelkin and Pollak analyzed the role of political parties within this discourse and continued to argue that parties' approach to the nuclear debate indicates that factors specific to the nuclear issue, particularly its technical nature as well as the government's close relationship with the nuclear industry, pushed nuclear energy towards depoliticization. Although they recognize that Germany was more resistant to depoliticization than France, they argue that the difference between the two countries (i.e. multiparty vs. a quasi-two-party system, conflict vs. consensus orientation, the extent to which the parties could access governmental power) only determined the path of the depoliticization as both countries were clearly undergoing this process. ${ }^{34}$ Written in 1980 , this article may have been valid at the time. However, with Merkel's abrupt decision to close all nuclear reactors, it can hardly be said that the issue has continued its path to depoliticization in Germany at least. Indeed, demonstrations throughout the 1990s and 2000s also challenge Nelkin and Pollak's argument. Still, it would be interesting in the future for other studies to measure degrees of current depoliticization in both countries to try to ascertain a relationship with policy outcomes after Fukushima.

While present in some activists' work in the 1970s and 1980s, the 'not cost effective' package did not really have the same dominance in the French or German experience (though it was presented as a counter-package in the post-Fukushima period

\footnotetext{
${ }^{33}$ Nelkin and Pollak, The Atom Besieged, 173.

${ }^{34}$ Dorothy Nelkin and Michael Pollak, "Political Parties and the Nuclear Energy Debate in France and Germany," Comparative Politics 12, No. 2 (January 1980), 139.
} 
in France). This package is described as a thoughtful cost-benefit analysis that suggests, "When one compares the costs and benefits of nuclear energy with the alternatives, it makes a poor showing...it is foolish to keep pouring good money after bad by supporting the continued development of nuclear energy." government. Joppke argues that the reasons for the decline of nuclear energy in West Germany and the United States in the 1980 s went beyond the impact of anti-nuclear movements. ${ }^{36}$ He indicates three main reasons for this decline: declining energy demands, expensive construction costs, and political pressures. ${ }^{37}$ While the 1979 Three Mile Island disaster sealed the decline of American nuclear power, nuclear power in Germany remained a major public policy concern during the 1980s. However, the 1986 Chernobyl disaster provided impetus for a similar decline in Germany for a decade at least.

Many of Joppke's points are echoed by Koopmans and Duyvendak who sought to examine the relationship between the construction of the nuclear energy issue and the subsequent mobilization of activist groups in France, Germany, Switzerland, and the Netherlands after the Chernobyl disaster. Their article is an attempt to examine the validity of two different models for the social movement mobilization: the grievance model and the frame alignment model. While previous literature emphasized the importance of a 'grievance' to mobilize action, Koopmans and Duyvendak rejected the validity of this model. They take the 1986 Chernobyl disaster as an opportunity to test

\footnotetext{
${ }^{39}$ Gamson and Modigliani, "Media Discourse and Public Opinion on Nuclear Power," 16-17.

${ }^{36}$ Joppke, "Social Movements during Cycles of Issue Attention," 43.

${ }^{37}$ Ibid., 47.
} 
their hypothesis as it provided a possible grievance for many countries at the same time. ${ }^{38}$ One of the major focuses within the framing literature in the last few decades has been the notion of political opportunities, namely changes in either institutional structure or informal systemic relationships, and how these changes can constrain or facilitate collection action frames and social movements' mobilization. ${ }^{39}$ While their article has a separate goal, the idea of political opportunities is present in Koopmans and Duyvendak's work. They frame the German reaction to Chernobyl as representative of 'German Angst' or its risk-oriented society in combination with contemporary political circumstances. Chernobyl actually occurred in the middle of a protest movement against the construction of a nuclear reprocessing plant in Wackersdorf, Bavaria. As public opinion had already been mobilized against nuclear energy, the movement already had a strong organizational capacity as well as a concrete 'fear' object in Chernobyl on which to further focus its mobilization. ${ }^{40}$ Koopmans and Duyvendak also noted a distinct shift in the traditional political rhetoric about nuclear energy within Germany at this time as more political representatives condemned nuclear energy while, even after Chernobyl, all political parties in France remained firmly in favour of nuclear power. ${ }^{41}$ This is important as it sets the stage for the state of elite consensus in each country at the time of the Fukushima disaster.

\footnotetext{
${ }^{38}$ Ruud Koopmans and Jan Willem Duyvendak, "The Political Construction of the Nuclear Energy Issue and Its Impact on the Mobilization of Anti-Nuclear Movements in Western Europe," Social Problems 42, no. 2 (May 1995), 237.

${ }^{39}$ Benford and Snow, "Framing Processes and Social Movements," 628.

${ }^{40}$ Koopmans and Duyvendak, "The Political Construction of the Nuclear Energy Issue," 239.

${ }^{41}$ Ibid., 240.
} 
According to the literature, there are two characteristics of collective action frames: the "core framing tasks" and the accompanying interactive processes that generate collective action frames. ${ }^{42}$ Snow and Benford identify these core framing tasks as diagnostic framing, prognostic framing, and motivational framing. ${ }^{43}$ These framing tasks are essential to social movements in defining a shared understanding of the problem and who is responsible, agreeing on a solution to this problem, and mobilizing others to act to implement this solution or change. ${ }^{44}$ The co-opting of political parties into this process is essential for enacting systemic change, and parties generally become involved if the movement conveys an appearance that it represents significant public support. Koopmans and Duyvendak also explain that political and institutional resistance can enact real barriers to the development of discourse:

In the Chernobyl case, the strong French state even successfully denied the existence of a problem and, in the absence of any competing version among the country's political elites, was able to convince the population that radiation had somehow halted at thecountry's borders, and that the unsafe nature of Soviet reactors was of no relevance to superior French nuclear technology. This interpretation of the problem may have been unreal, but it was perfectly real in its consequences. $^{45}$

Thus, despite the fact that 1978 French public opinion was still favourable to the antinuclear movement, which had achieved higher mobilization levels than any other

\footnotetext{
${ }^{42}$ Benford and Snow, "Framing Processes and Social Movements," 615.

${ }^{43}$ Ibid., 615.

${ }^{44}$ Ibid., 615.

${ }^{45}$ Koopmans and Duyvendak, "The Political Construction of the Nuclear Energy Issue," 249.
} 
contemporary European anti-nuclear movement, this mobilization was unable to manifest change in a highly centralized political system that was resistant to intervention. ${ }^{46}$

Nelkin and Pollak echoed this conclusion by stating that "[t]he greater impact of the protest in Germany than in France followed less from the characteristics of the movement itself - a movement often paralyzed by internal schisms over tactics and longterm goals - than on... points of access within the political system and on the ability of activists to exploit them. ${ }^{, 47}$ These points of access refer to Germany's federal system in which multiple levels of government provide several more 'input' mechanisms than France's centralized structure with a strong executive. ${ }^{48}$ Furthermore, Germany's Atomic Energy Act provided activists with mechanisms for legal and administrative challenges. ${ }^{49}$ Independent of the political executive, the judiciary provided German activists with some victories that allowed the movement to continue its momentum far longer than the French movement's expiration around 1981. For the purposes of this paper, these institutional characteristics are captured under the notion of historical experiences as they are stable, long-term features but some might consider them political opportunities. This paper rejects that application, as it understands political opportunities to be 'windows' with limited-term potential for action. Therefore, while institutions may generate political opportunities through elections and such, they are not political opportunities themselves.

\footnotetext{
${ }^{46}$ Koopmans and Duyvendak, "The Political Construction of the Nuclear Energy Issue," 244.

${ }^{47}$ Nelkin and Pollak, The Atom Besieged, 195-196.

${ }^{48}$ Ibid., 195-196.

${ }^{49}$ Ibid., 195-196.
} 
While the majority of literature on mobilization in the 1970s and 1980s is qualitative, Kolb offers an excellent quantitative analysis of changes in nuclear programs in eighteen Organisation for Economic Co-operation and Development (OECD) countries during the mass protests of the 1970s and fourteen OECD countries after the Chernobyl nuclear disaster. He considers the relative impact of the following variables on nuclear policy development: movement strength, political institutional structure, elite conflict, stability of political alignments, public opinion, political crisis, population size, and energy import dependence. He proposes several hypotheses with these variables with the most relevant (given Kolb's eventual results) being: “even strong anti-nuclear mobilization can only succeed if political opportunities are present"; "the more open a country's institutional structure, the greater is the impact of the anti-nuclear energy movement"; "the more political elites are split on the issue of nuclear energy, the greater the impact of the anti-nuclear movement"; and "the greater the public's hostility toward the nuclear energy, the greater is the impact of the anti-nuclear energy movement." While this paper does not share Kolb's explicit focus on social mobilization, these hypotheses will inform some of this paper's assumptions going forward.

Kolb constructed an original index of 'nuclear program deviation,' which describes "the degree of change in a country's nuclear program in the years immediately after the [Chernobyl] accident." ${ }^{, 51}$ To calculate this variable, he studied the plans for the construction of nuclear power plants within the countries of study and gathered

\footnotetext{
${ }^{50}$ Felix Kolb, Protest and Opportunities: The Political Outcomes of Social Movements (Chicago: University of Chicago Press, 2007), 202-212.

${ }^{51}$ Kolb, Protest and Opportunities, 16.
} 
quantitative data on the status of every nuclear project under construction, planned, or projected. ${ }^{52}$ He then compared this information annually by country to present a percentage of nuclear program deviation in response to the anti-nuclear movement. France was awarded a $0 \%$, which means that there was no discernible shift in its policy because of anti-nuclear mobilization, while Germany scored $34 \%$, which means $34 \%$ of the potential nuclear program could not be realized by the nuclear industry because of anti-nuclear mobilization..$^{53} \mathrm{He}$ then performed bivariate correlation analysis on some of the eight variables along with qualitative comparative analysis for the remaining variables to perform a multivariate analysis. ${ }^{54}$ Through this statistical analysis, Kolb ultimately concludes that:

Public opinion and elite conflict obviously have a causal influence on nuclear program deviation. Although the statistical analysis suggested that movement strength and institutional structure do not influence nuclear outcomes, a more indepth analysis of the data suggested that both variables might have been important. Institutional openness seems to present a political opportunity when anti-nuclear protest is directed against nuclear program implementation. The impact of movement strength is contingent on political opportunities - either on intense elite conflict, strongly anti-nuclear public attitudes, or very open institutional structures. ${ }^{55}$

Kolb articulated this idea in the expression, Nuclear Change $=$ Mobilization (Elite*Majority + Structure), or nuclear change occurs when sustained mobilization is accompanied by both elite support and an anti-nuclear public majority, or by institutional

\footnotetext{
${ }^{32}$ Kolb, Protest and Opportunities, 197.

${ }^{53}$ Ibid., 198-199.

${ }^{54}$ Ibid., 17.

${ }^{53}$ Ibid., 224-225.
} 
structures that are open or responsive to change. ${ }^{56}$ In applying this idea to political change after Chernobyl, Kolb created the expression, Nuclear Change $=$ Majority(Election + Structure), or that nuclear program deviation can be obtained through the presence of an anti-nuclear public majority accompanied by either a 1986 national election or an institutional structure that was open or responsive to change. ${ }^{57}$ However, as both France and Germany exhibited similar post-Chernobyl reactions as their Fukushima reactions, this lends support to the idea that there may be broader institutional factors at work beyond the short-term political contexts in which the French and German governments operated.

The 1990s marked a decline of anti-nuclear protest in both countries. In the French case, the annihilation of the French anti-nuclear movement after 1981 had seemingly produced the related 'runaway' or 'devil's bargain' packages in the public consciousness. Gamson and Modigliani describe these packages as "gallows humor [that]... suggests resignation and fatalism more than opposition" and recognition of "clear benefits such as inexhaustible electricity and [a reliable] energy supply...[b]ut sooner or later, there will be a terrible price to pay" respectively. ${ }^{58}$ In other words, French nuclear energy was a fact of life despite its risks. Both of these packages also have religious undertones, with 'runaway' promising retribution for playing God and 'devil's bargain' promising damnation in exchange for the forbidden nuclear gift. ${ }^{59}$ The German public

\footnotetext{
${ }^{56} \mathrm{Kolb}$, Protest and Opportunities, 228.

${ }^{57}$ Ibid., 234.

${ }^{58}$ Gamson and Modigliani, "Media Discourse and Public Opinion on Nuclear Power," 20; 25.

${ }^{59}$ lbid., 20; 25.
} 
continued to express 'soft paths' and 'public accountability' packages, but overall demonstrations declined. ${ }^{60}$ Joppke suggests that this was because the entry of the Green Party and its opposition to nuclear energy into the political system reduced the need for extraparliamentary action. ${ }^{61}$

The 2000s marked a 'nuclear renaissance' in Europe, and some may argue globally. It may be argued that this renewed interest in nuclear energy was a result of a new emerging package, 'low-carbon alternative,' which described nuclear energy as an environmentally friendly energy source. It also marked a period where the EU was beginning to formulate a joint energy strategy. With its energy demands rising on average $1-2 \%$ per year, the EU is struggling to meet these new needs while shifting to sustainable and renewable energy resources. In its 2006 Green Paper, $A$ European Strategy for Sustainable, Competitive and Secure Energy, the EU articulates its core energy objectives as competitiveness, sustainable development, and security of supply ${ }^{62}$

This 2006 paper led to the development of the EU's Energy 2020 initiative that was published in November 2010. In terms of nuclear energy, the initiative notes that nearly $45 \%$ of European electricity is based on low-carbon energy sources, including nuclear energy, and that some EU members could lose more than a third of their energy capacity in the next decade because of the limited lifetime of nuclear plants. Thus, the initiative aims to replace and expand such installations while searching for secure non-

\footnotetext{
${ }^{60}$ Germany continued to witness anti-nuclear demonstrations throughout the $1990 \mathrm{~s}$ and $2000 \mathrm{~s}$, but their quantity and intensity paled against those of the 1970 s and $1980 \mathrm{~s}$.

${ }^{61}$ Joppke, "Social Movements during Cycles of Issue Attention," 51.

${ }^{62}$ Special Eurobarometer 262: Energy Technologies: Knowledge, Perception, Measures. Published January 2007, with fieldwork May - June 2006. Retrieved from http://ec.europa.eu/public opinion/ archives/ebs/ebs_262_en.pdf on 12 February 2013; 2.
} 
fossil fuel alternatives. ${ }^{63}$ France was a large part of the lobby to include this nuclear energy provision as part of the EU's low-carbon strategy. However, the Energy 2020 initiative also states:

The contribution of nuclear energy...must be assessed openly and objectively. The full provisions of the Euratom Treaty must be applied rigorously, in particular in terms of safety. Given the renewed interest in this form of generation in Europe and worldwide, research must be pursued on radioactive waste management technologies and their safe implementation, as well as preparing the longer term future through development of next generation fission systems, for increased sustainability and cogeneration of heat and electricity, and nuclear fusion (ITER). ${ }^{64}$

The 2020 Initiative also promises legislative changes to enhance nuclear safety, including safety standards for the protection of nuclear workers and the public, greater harmonisation of plant design, as well as a European approach to nuclear liability regimes. ${ }^{65}$

Despite the apparent inclusion of nuclear energy as a key pillar of EU energy policy, nuclear energy remains a divisive issue amongst member states. $37 \%$ of European respondents surveyed in a 2006 Eurobarometer report indicated their opposition to this energy source with an absolute majority in seven countries doing the

\footnotetext{
${ }^{63}$ European Commission, Communication From The Commission To The European Parliament, The Council, The European Economic And Social Committee And The Committee Of The Regions Energy 2020 A Strategy For Competitive, Sustainable And Secure Energy, 10 November 2010. Retrieved from http://eur-lex.europa.eu/LexUriServ/LexUriServ.do?uri=CELEX:52010DC0639:EN:HTML:NOT on 11 January 2013.

${ }^{64}$ European Commission, Communication From The Commission To The European Parliament, 10 November 2010.

${ }^{65}$ Ibid., 10 November 2010.
} 
same. ${ }^{66}$ Thus, the 2000 s could be said to mark a period of nuclear renaissance while latent nuclear resistance still lay bubbling beneath the surface.

This brings us to the period of study - 2011. As the Fukushima nuclear incident occurred only two years prior to the writing of this paper, secondary literature on its impacts on nuclear policy generally remains negligible. However, recent publications suggest that this may be starting to change. For example, David Elliot's book Fukushima: Impacts and Implications provides a general overview of public and government reaction worldwide ${ }^{67}$ However, coverage of France and Germany's reaction in this particular volume amounts to less than ten pages. Other authors have also provided slim summaries of both countries' reactions. ${ }^{68}$ Therefore, this paper has an opportunity to make a contribution to study within this field through the application of the theories promoted by past literature to a post-Fukushima context.

\subsection{Methodology}

From this literature review, several themes emerge: the secretive relationship between the government executive, bureaucracy, and nuclear industry and its impacts on public transparency and democracy; the changing public opinion towards nuclear energy; the success or failure of anti-nuclear movements as dependent on political opportunities; and the influence of France and Germany's institutions in shaping those opportunities. This review also provided Kolb's quantitative evaluation of the influence of variables across a wide sample set of eighteen OECD countries, which ultimately concluded that

${ }^{66}$ Special Eurobarometer 262: Energy Technologies: Knowledge, Perception, Measures, $27 ; 31$.

${ }^{67}$ David Elliot, Fukushima: Impacts and Implications (Palgrave Macmillian, 2012).

${ }^{68}$ B.B.F. Wittneben, "The impact of the Fukushima nuclear accident on European energy policy." Environmental Science \& Policy 15 (2012):1-3. 
there was a causal influence of public opinion and elite consensus on nuclear program change while also providing some support for institutional openness and the importance of political opportunities in facilitating change. While these latter two factors may not have received quantitative causal validation across the wider OECD sample, it is likely that they have a larger role in a direct comparison between the French and German cases.

Given the similarity of the Chernobyl and Fukushima cases, the Fukushima case study would be an excellent opportunity to conduct a quantitative analysis comparable to that of Kolb. However, as the Fukushima nuclear disaster only occurred two years ago at the time of writing, it is unlikely that the full political outcomes of this disaster can be appreciated at this time. In his assessment of post-Chernobyl political outcomes, Kolb notes that the evidence supports the idea that responsive political concessions were likely to be short-lived.$^{69}$ For this reason, a quantitative analysis is not feasible at this time.

Yet there are still some areas in which an analysis of the short-term political outcomes could benefit future research. Kolb's quantitative analysis of political change after the Chernobyl disaster suggests that public opinion is one of the strongest and most consistent factors in explaining nuclear policy change, and other literature discusses how public opinion intersects with political opportunities and institutional structures (under which some authors include elite consensus) to produce political change. This paper builds upon these conclusions to argue that Fukushima merely offered a prime political opportunity for the vocalization of dissent to the governing institutions of France and Germany, and ultimately the permeability of these institutions, determined by their historical development, elite consensus, and available political opportunities for public

\footnotetext{
${ }^{69}$ Kolb, Protest and Opportunities, 251.
} 
influence on decision-making institutions, shaped each country's response. This is not to say that the same outcome would have been achieved without the Fukushima disaster; rather, France and Germany's past responses to political opportunities on nuclear energy created a culture that enabled or prevented further political opportunities on this issue to emerge. It could therefore be said that this paper employs an historical institutionalism approach in that both countries' experiences 'set the scene' for their respective reactions but it was only with the Fukushima trigger that these experiences were able to exert themselves. In a sense, this conforms to the concept of path dependency, which states that once certain events have triggered reactions in a specific context, these reactions and dynamics are likely to reproduce and reoccur in the future even in the absence of the originating event(s).

Through the literature review, this paper attempted to establish how the nuclear energy issue was framed throughout each country's experience in the development of their nuclear program. This paper will now turn to establishing how, if framing has taken place and there is a political opportunity, a policy change is more likely to take place if there is diverging opinion amongst the political elite and public opinion is supportive of the change. This paper hypothesizes that three factors help explain the differential French and German outcomes. First, in reference to both countries' institutions that were shaped by their post-WWII experiences, it is hypothesized that a centralized government structure is more resistant to external pressure and expertise about the impacts of nuclear energy through a monopoly on jurisdiction and directives, as in France, while a federal government structure is more vulnerable to external pressure and expertise about the impacts of nuclear energy as jurisdiction and directives are shared, as in Germany. To 
further reinforce the historical trends in both governments' Fukushima reactions, Gamson and Modigliani's 'packages' that were referenced within the chronological literature review will be referred to in order to establish some historical parallels. Second, in reference to the importance of public opinion as demonstrated in the literature but with recognition that French dissent did not enable change, it is hypothesized that a democratic government is more resistant to external pressure for policy action the farther it is from facing an election cycle. Inversely, a democratic government is more vulnerable to external pressure for policy action the closer it is to facing an election cycle. Third, in reference to Kolb's research that elite consensus is a determining factor in nuclear policy change, it is hypothesized that the more political elites are divided on the issue of nuclear energy, the greater the impact of anti-nuclear sentiment in achieving a policy change. However, this hypothesis comes with a caveat; this hypothesis only describes the state of the elite consensus at the time when the political opportunity first appears. As will be shown, the elite consensus in both countries changed throughout the course of the period studied. For this reason, elite consensus might be conceived of as an element of the framing process.

To forward this argument, this paper will examine how the Fukushima nuclear disaster is documented in two national newspapers, Le Monde in France and Süddeutsche Zeitung in Germany, from 11 March to 18 June 2011. However, to reduce the possibility that each newspaper's editorial stance skewed the analysis, media coverage from four other newspapers was considered. These four newspapers include two French newspapers, Le Figaro and Libération, as well as two German newspapers, Berliner Zeitung and Die Welt, that cover a range of editorial stances. While Le Monde and 
Süddeutsche Zeitung are used to establish the main narrative of France and Germany's respective reactions, the other four newspapers are used to validate key points of this narrative and, if their perspective differs from the main sources, to provide additional components for consideration. Methodologically, both the print and online editions of Le Monde and Süddeutsche Zeitung were used while only the print editions were used for the other four newspapers, as the print editions were more likely to have analysis and commentary as opposed to mere events reporting.

To analyze French media coverage of the Fukushima nuclear disaster, the daily newspaper Le Monde was selected. Printed in Paris, Le Monde has a daily circulation of approximately 320,000 and is national in scope. Le Monde was selected as its issues from 11 March 2011 and 18 June 2011 were easily accessible through the Eureka.cc online database, and because it focused more on analysis than simply providing an accounting of the events in Japan as they unfolded. This was critical as this paper is interested in how the Fukushima nuclear disaster was understood and how it was perceived in relation to France's domestic situation. As the newspaper is currently perceived as having a centreleft bias, there was concern that the newspaper would misrepresent the full discussion happening in France at the time. Therefore, its analysis will be supplemented by the examination of two other French newspapers' coverage of the Fukushima disaster, Le Figaro and Libération, which are both available through the Factiva online news database. Le Figaro is the second largest national newspaper in France and is considered to have a conservative editorial approach. On the other hand, Libération is considered to have a left editorial approach and has a circulation of approximately 140,000. 
The Süddeutsche Zeitung is the largest national German daily newspaper, with approximately 1.1 million daily readers. Available through the Factiva online database, it is published in Munich in the state of Bavaria. Süddeutsche Zeitung was chosen as the main German daily newspaper for several reasons, despite its regional headquartes in comparison to the Paris Le Monde. Bavaria has been under conservative control almost continuously since 1949 and was the biggest proponent of nuclear power in Germany. This made Bavaria's nuclear policy stance comparable to that of the French national government so this newspaper operates in a similar context as the French national papers. Furthermore, given its wide circulation in contrast to the approximately 320,000 daily copies sold by Le Monde, Süddeutsche Zeitung has a significantly wider national audience on which it may exert influence. Its editorial orientation can be described as centre-left or liberal. To mitigate possible skewing of the German case study by Süddeutsche Zeitung's editorial approach, this paper analyzed two other German newspapers, Berliner Zeitung and Die Welt, which are also both available through the Factiva database. ${ }^{70}$ Berliner Zeitung also employs a centre-left orientation but it is one of the largest newspapers concentrated in Germany's capital, which provides a different perspective than the Bavarian Süddeutsche Zeitung. Founded in the other German state/city of Hamburg, Die Welt has a circulation of over 200,000 and is generally considered to have a conservative orientation.

This media analysis was selected to address this paper's two main arguments and three hypotheses for several reasons. First, this approach provides an opportunity to

\footnotetext{
${ }^{70}$ The Frankfurter Allgemeine Zeitung was the author's initial choice for a conservative German newspaper but its coverage from the study period was not available through any online or print form without payment. Therefore, Die Welt was selected as a suitable substitute.
} 
explore how historical framing was referenced and applied to the Fukushima disaster by each public through their national newspapers. One of the foundations of this paper is that each country's historical experiences that shaped their institutions and previous reactions to anti-nuclear mobilizations subsequently shaped their Fukushima reaction. To this end, media analysis provides a way to catch a glimpse of how each public reflected on its past nuclear experiences and the parallels that the media drew between these past experiences and the present Fukushima situation. Second, by tracing events as they unfolded within media coverage, this paper is able to examine how political opportunities were shaped and understood during this time. Third, a media analysis allows this paper to explore explanations that past literature identified as important despite the fact that the Fukushima crisis occurred only two years ago at the time of writing and available data or analysis remains limited. This paper cannot hope to establish causality or identify statistically significant variables that shaped each country's response at this point in time, simply because the full political impacts of the Fukushima disaster are not yet known. For example, a year after the Fukushima crisis, François Hollande won the French presidency and committed to halving France's reliance on nuclear energy as well as closing the titular Fessenheim; however, none of these ambitions have been realized yet and his commitment to follow through on them has recently been questioned. Therefore, what this paper does hope to accomplish is to establish a narrative of each country's reaction to the Fukushima disaster and provide a compelling explanation for the how and why this narrative manifested itself in each country's policy response. It is the author's hope that a future study will take a similar approach to the Fukushima disaster as Kolb's quantitative analysis of Chernobyl policy reactions to provide more substantive evidence 
concerning the importance of the identified variables, and that this paper might provide a starting point for determining how those variables should be analyzed.

Upon reviewing the media coverage of each newspaper, five main themes emerged: transparency and democracy concerns about the nuclear issue as well as the close relationship between nuclear industry and government; the French government's response through its traditional packages; the German government's response through its campaigning during four regional elections during the survey period; degrees of elite consensus in France and Germany; and France and Germany's reaction to each other's policy and how this manifested in the European pursuit of a shared energy policy. This analysis will thus be organized using a thematic approach, and this paper will now contextualize France and Germany's reactions to the 2011 Fukushima nuclear disaster before offering a media analysis within these five themes. 


\section{Chapter: Contextualizing Reactions to the Fukushima Disaster}

Having established this paper's approach, this chapter will now provide an overview of each state's political and nuclear institutions as a reference for the subsequent media analysis, as well as an overview of public attitudes toward nuclear energy immediately prior to Fukushima. As stated in the previous chapter's literature review, France and Germany have historically responded to anti-nuclear dissent quite differently. However, the 2000s provided an opportunity for a nuclear renaissance in which the pendulum shifted back to a generally positive attitude towards nuclear energy. Therefore, this section will explore each state's nuclear context as well as the French and German public's attitudes towards nuclear energy in the five years prior to the Fukushima disaster in order to establish a baseline for comparison.

\subsection{France's Political and Nuclear Institutions}

As a semi-presidential system, the Fifth Republic took elements from the presidential model and its traditional parliamentary model. The French President controls the executive branch and the parliament's agenda, but is independent of the legislature. ${ }^{1}$ The President is elected for five-year terms and can only serve two consecutive terms. The Parliament consists of the National Assembly and the Senate and, while the National Assembly is stronger than the Senate, it can only directly wield influence on the prime minister not the president. Subsequently, governments generally do not fear the National Assembly as they hold a majority. ${ }^{2}$ While there have been some trends towards the

\footnotetext{
'Mark Kesselman, "France," in Introduction to Comparative Politics: Political Challenges and Changing Agendas, Sixth Edition, ed. Mark Kesselman, Joel Krieger, and William A. Joseph, 90-137. (Wadsworth: Cengage Learning, 2013), 113.

${ }^{2}$ Kesselman, "France," 121.
} 
decentralization of certain roles and responsibilities, France remains a highly centralized system with most decision-making resting with the executive. ${ }^{3}$

There are three main political parties of interest in an examination of France's reaction to the Fukushima disaster: the Union pour un mouvement populaire (Union for a Popular Movement - UMP), the Parti socialiste (Socialist Party - PS), and Europe Écologie - Les Verts (Europe Ecology - The Greens or EELV). While the Front national (National Front - FN) is a political force in France, it did not make a significant impact on the nuclear energy debate. The conservative UMP is the successor to the Gaullist party (the name changed in 2002), and a perpetual supporter of nuclear energy. While the PS leader François Mitterrand's election platform in 1981 called for the ceasing of the nuclear program, political realities after Mitterrand's election caused him to revert to his previous support of nuclear energy. From that point, the PS supported nuclear energy until Fukushima caused some internal party divisions. The EELV was formed in 2010 from the former Les Verts and other environmentalists; ironically, the EELV actually supported nuclear energy prior to Fukushima and minimized its public opposition to it during local elections in the period of study.

Elected in 2007, President Sarkozy (UMP) led the government's response to the Fukushima crisis. Should the same party win both the presidential and parliamentary elections, it is said that the French president is comparatively one of the strongest executives in the democratic world. ${ }^{4}$ Sarkozy was in this enviable position at the time of

\footnotetext{
${ }^{3}$ Kesselman, "France," 111.

${ }^{4}$ Ibid., 113.
} 
the Fukushima disaster. With the next presidential election only a year after the Fukushima disaster, there is no doubt that 2012 considerations guided some of Sarkozy's reaction. Other key government players during the Fukushima crisis included Prime Minister François Fillon (UMP); Éric Besson (UMP), who served as Minister of Industry, Energy and Digital Economy under the Minister of Economy, Finance and Industry Christine Lagarde (UMP); and Nathalie Kosciusko-Morizet (UMP), Minister for Ecology, Sustainable Development, Transport and Housing.

At the time of the Fukushima nuclear disaster, France had the second largest nuclear fleet in the world after the United States with 58 nuclear reactors in 19 sites throughout the country. ${ }^{5}$ The importance of this nationalized sector and the early ties between the civil and military aspects of nuclear power in France established a pattern of strong central government control over nuclear policy. This control remains to this day unfettered by legislation dealing specifically with nuclear technology. ${ }^{6}$ In terms of institutions, there are four main French nuclear institutions: Commissariat à l'énergie atomique (CEA), Electricité de France (EDF), Areva, and the Autorité de sûreté nucléaire (Nuclear Safety Authority - ASN). While some of these are technically private companies, the state owns more than three-fourths of these companies so for the purposes of this paper, they are considered French public institutions.

Created in 1945, France's CEA is a public entity who is responsible for the commercial and industrial development of nuclear energy, including military

\footnotetext{
3 "Accident nucléaire au Japon : les autorités françaises se veulent rassurantes," LeMonde.fr, 13 March, Eureka.cc.

${ }^{6}$ Dorothy Nelkin and Michael Pollak, The Atom Besieged: Extraparliamentary Dissent in France and Germany (Cambridge, Massachusetts: MIT Press, 1981), 11.
} 
applications. In December 2009, President Sarkozy announced that the CEA's name would change to Commissariat à l'énergie atomique et aux énergies alternatives, which took effect on 10 March $2010 .^{7} \mathrm{EDF}$, the state-owned utility that is France's main electricity company, assumed increasing control of France's nuclear direction as nuclear energy became increasingly commercialized in the late 1960 s. $^{8}$ EDF's growing influence prompted tension between CEA and EDF, personified by EDF's support of the American light-water reactor while CEA wanted to stay with the 'home-grown' French gas-graphite technology. ${ }^{9}$ In other words, the EDF wanted to focus on a nationalized energy strategy to maximize exports while the CEA sought to establish a nationalist nuclear industry. ${ }^{10}$ The EDF ultimately won this fight for dominance in nuclear policy, which limited CEA's influence and allowed EDF essentially to control nuclear energy development in cooperation with the major industrial firms. ${ }^{11}$

Areva is a French public multinational industrial energy conglomerate that is mainly known for nuclear energy. It was created on 3 September 2001 by the merger of three former energy companies and its main shareholder is the CEA, which owns more than three-quarters of the company. Led by Anne Lauvergeon since its creation, Areva

\footnotetext{
${ }^{7}$ Vincent Collen, "Le Commissariat à l'énergie atomique élargit son champ aux énergies alternatives," LesEchos.fr, 15 December 2009. Retrieved from http://www.lesechos. fr/15/12/2009/LesEchos/20573-13ECH le-commissariat-a-l-energie-atomique-elargit-son-champ-aux-energies-alternatives.htm on 13 February 2013.

${ }^{8}$ Nelkin and Pollak, The Atom Besieged, 12.

${ }^{9}$ Ibid., 12.

${ }^{10}$ Gabrielle Hecht, Radiance of France: Nuclear Power and National Identity after World War II (Cambridge, MA: MIT Press, 2009).

${ }^{11}$ Nelkin and Pollak, The Atom Besieged, 12.
} 
often clashes with EDF over their joint ventures. ${ }^{12}$ This is perhaps a leftover of the historic tensions between the CEA and EDF.

The last major French nuclear institution is the ASN. Created in 2006, ASN is an independent organization dedicated to ensuring transparency and safety. There is no legal framework governing France's nuclear policy so the government is essentially given free rein with the ASN acting as a watchdog.

\subsection{Germany's Political and Nuclear Institutions}

Compared to France, Germany is a parliamentary democracy with a federal structure that does not have a strong separation of responsibilities between levels of government. This means that the sixteen states (Länder) have considerable power over federal policy, albeit less in the realm of nuclear policy. The President is a ceremonial role, elected by the Federal Convention for five-year terms, while the Chancellor is the head of government and the leader of the majority party or coalition in the Bundestag, which is elected every four years. The sixteen states select 69 individuals who represent them in the upper house, the Bundesrat. The legislative orientation of the Bundesrat depends on the political party controlling the majority of state governments as each state delegation votes on legislation in a bloc. ${ }^{13}$

There are four German political parties that are of interest to this examination: the Christian Democrats (CDU or CSU, as it is known in Bavaria), the Social Democratic

\footnotetext{
${ }^{12}$ Peggy Hollinger, "Areva and EDF spat shows nuclear tensions," Financial Times, 19 January 2010. Retrieved from http://www.ft.com/cms/s/0/6d4e729e-052a-11 df-a85e-00144feabdc0.html\#axzz2PRGs5SiZ on 14 February 2013.

${ }^{13}$ Christopher S. Allen and Wade Jacoby. "Germany," in Introduction to Comparative Politics: Political Challenges and Changing Agendas, Sixth Edition, ed. Mark Kesselman, Joel Krieger, and William A. Joseph, 138-187 (Wadsworth: Cengage Learning, 2013), 172.
} 
Party (SPD), the Free Democratic Party (FDP), and the Greens. The conservative CDU has dominated post-war German politics and, with its smaller preferred coalition partner of the liberal FDP, have traditionally supported nuclear power. So too did the SPD in the late 1970 s, until it shifted its policy to call for the abandonment of nuclear energy in 1986. The FDP and SPD's positions do have a caveat however as their support is far more subject to regional variations as well as public opinion. ${ }^{14}$ One of the reasons behind the formation of the Greens in 1979 was opposition to nuclear energy, and this issue continues to unite the party to this day; this is significant due to their triumph in the German state-level elections held after the Fukushima disaster.

The current Chancellor, Angela Merkel (CDU), was elected in 2005 and at the time of the Fukushima incident, she was governing with her preferred coalition partner, the FDP. President Christian Wulff did not play a major role in Germany's Fukushima reaction. Other important federal government officials included FDP leader and Foreign Minister, Guido Westerwelle, and the Federal Minister for Environment, Nature Conservation and Nuclear Safety, Norbert Röttgen. Also important for this examination is former Premier (or Minister-Präsident) of Baden-Württemberg, Stefan Mappus.

There is not the same degree of nuclear 'institutions' in Germany as in France. Regular government regulation is conducted by the Federal Ministry for the Environment, Nature Conservation and Nuclear Safety, but Merkel appointed a special expert nuclear safety commission to advise on the state of the German fleet after Fukushima. There are four major nuclear energy companies in Germany: E.ON,

${ }^{14}$ S.D. Thomas, The Realities of Nuclear Power: International Economic and Regulatory Experience (Cambridge: Cambridge University Press, 2009): 138-139. 
Vattenfall, RWE, and EnBW. Prior to the German phase-out, E.ON operated six nuclear plants, Vattenfall operated three, RWE operated five, and EnBW operated three plants. The German firm, Siemens, also designed most of the nuclear power plants in Germany.

It is also important to note that, unlike France, Germany has an Atomic Energy $A c t$, which provides a legal framework for its nuclear energy approach. This law also provides recourse for anti-nuclear activists and has in fact been used to slow or stop construction of several nuclear power plants in the 1970s and 1980s. While it is not a major focus of this paper, there is no question that the German legal system has an important institutional influence on the country's nuclear approach.

\subsection{Public Attitudes Toward Nuclear Energy}

In terms of French and German opinions towards nuclear energy, there were three Eurobarometer studies in the five years prior to the Fukushima nuclear incident: the 2006 Special Eurobarometer 262: Energy Technologies: Knowledge, Perception, Measures; the 2006 Special Eurobarometer 271: Europeans and Nuclear Safety; and the 2009 Special Eurobarometer 324: Europeans And Nuclear Safety, which was a three-year update to Special Eurobarometer 271. These surveys provide a comparable dataset to examine French and German attitudes towards nuclear energy prior to Fukushima as well as some insight of the reasoning behind these attitudes.

The most relevant results in describing the French and German public's overall attitude towards nuclear energy from these three surveys can be viewed in Table 1 on the next page. However, this paper will also provide an overview of some other results that may be important to the analysis of each country's response to the Fukushima disaster. 
Summary of French and German Results from Eurobarometer 262 (2006), 271 (2006), and 324 (2009)

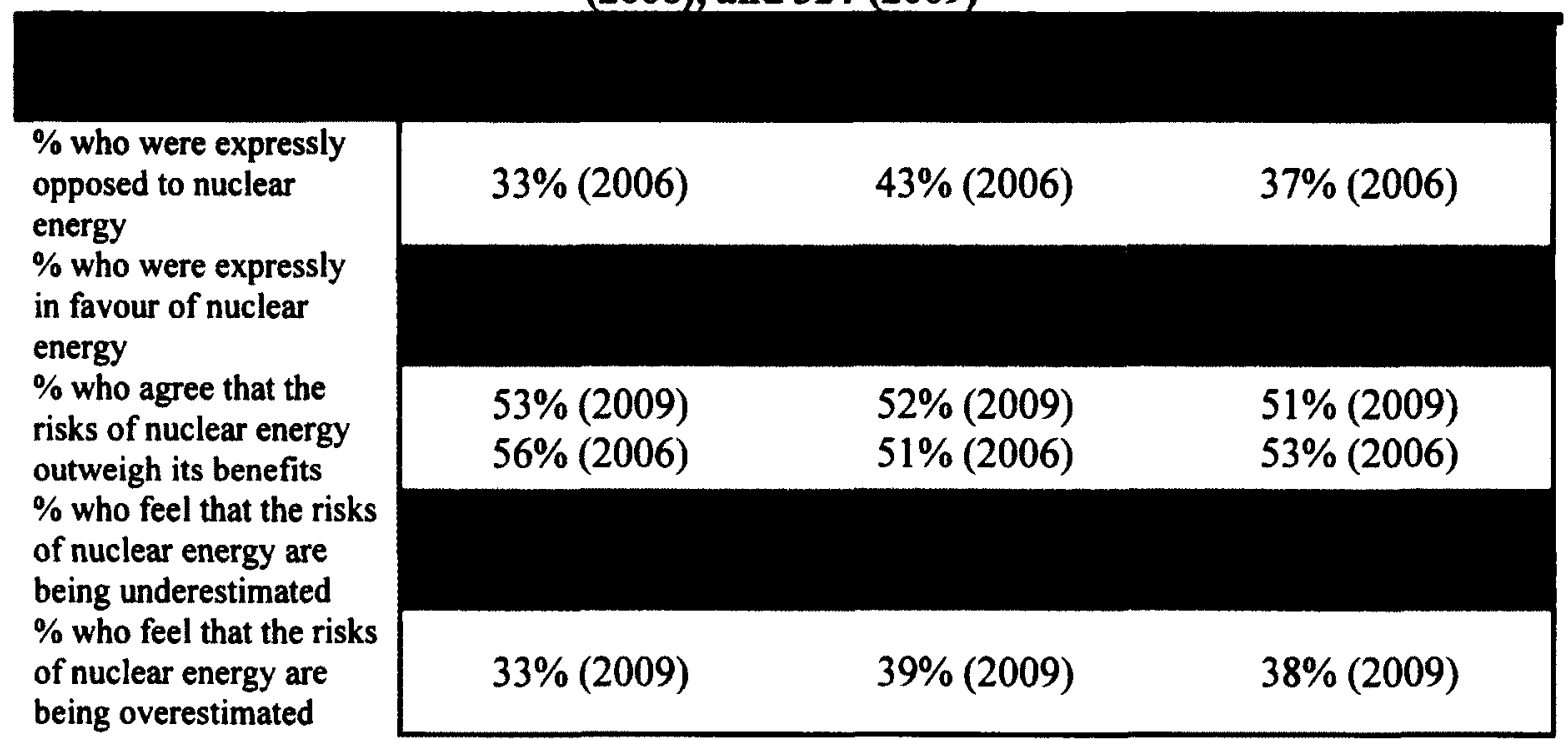

Table 1 Summary of Results from Eurobarometer 262, 271, and 324

According to the 2006 Special Eurobarometer 262: Energy Technologies:

Knowledge, Perception, Measures, results for France and Germany were comparable $33 \%$ of French respondents were expressly opposed to nuclear energy with $21 \%$ in favour and $44 \%$ with 'balanced' views, while $43 \%$ of German respondents were opposed with $20 \%$ in favour and $34 \%$ with balanced views. ${ }^{15}$ Yet French and German respondents differed in their perspectives and expectations of what should determine their national government's approach to energy policy. In a survey question that allowed multiple answers, the top two French responses were guaranteeing low prices for consumers (41\%) and protecting the environment (45\%). Interestingly, $46 \%$ of German respondents stressed guaranteeing low prices for consumers with $45 \%$ mentioning the guaranteeing of a continuous supply of energy (in contrast to $16 \%$ for France). Only $24 \%$ of German

${ }^{15}$ Special Eurobarometer 262: Energy Technologies: Knowledge, Perception, Measures. Published January 2007, with fieldwork May - June 2006. Retrieved from http://ec.europa.eu/public opinion/ archives/ebs/ebs 262 en.pdf on 12 February $2013,32$. 
respondents mentioned protecting the environment. ${ }^{16}$ These results add an interesting nuance to a comparison between France and Germany as both populations expected consumer pricing to be a key driver in nuclear policy development but twice the amount of French respondents expected environmental protection to be a policy consideration. This challenges Chernobyl-era narratives of the German environmentalist taking to the streets, or being inherently more environmentally conscious or more in tune with the natural world than the French. It also raises the issue of whether the French saw nuclear energy as environmentally friendly or unfriendly; do they see nuclear energy as protecting the environment as a low-carbon alternative as per the French government's narrative or is its waste considered to be an environmental risk and toxin? A later survey suggests that many French respondents rejected parts of their government's national narrative as equal shares of respondents agree and disagree $(41 \%)$ with the statement that nuclear energy limits global warming. ${ }^{17}$ In contrast, what explains Germany's general support of nuclear energy with $54 \%$ in favour or with balanced views? Given the importance that the EU placed on reducing carbon-based energy sources, it is possible that general German support for nuclear energy may have been mediated by a sense of European identity within the country over the last decade or economic considerations, but these potential explanations would be difficult to establish.

The economic considerations of nuclear energy for both countries were significant. At the time of the 2006 survey, $78.5 \%$ of France's electricity and $31 \%$ of

\footnotetext{
${ }^{16}$ Special Eurobarometer 262, 40.

${ }^{17}$ Special Eurobarometer 271: Europeans and Nuclear Safety. Published February 2007, OctoberNovember 2006. Retrieved from http://ec.europa.eu/public opinion /archives/ebs/ebs 271 en.pdf on 12 February $2013 ; 6$.
} 
Germany's electricity was produced by nuclear energy. ${ }^{18}$ Both the French and German citizenry had a generally accurate understanding of nuclear energy's predominance in meeting their individual country's energy needs with $78 \%$ of French respondents identifying nuclear energy as a top three energy source for France while $54 \%$ of German respondents did the same for Germany. ${ }^{19}$ While this seems to suggest that Germans misunderstood nuclear energy's importance in their domestic energy mix, nuclear energy was in fact the country's second largest energy source after coal and lignite in $2009 .^{20}$ According to Special Eurobarometer 271: Europeans and Nuclear Safety, which also had a 2006 survey period, $39 \%$ of the European population wanted to reduce nuclear energy's share of their national electricity mix but about half of Germans (50\%) and French (49\%) did so. ${ }^{21}$ This result is significant because it indicates a comparable desire to move away from, or at the very least reduce, domestic nuclear power production, which lends support to this paper's comparative analysis of France and Germany. Furthermore, both French and German respondents expected that their reliance on nuclear energy would decrease in the next thirty years while shifting to a greater reliance on solar and wind energy. ${ }^{22} 32 \%$ of Germans thought that this shift could be done easily while the French were more optimistic at $56 \% .{ }^{23}$ This result is striking not only because nuclear

${ }^{18}$ Special Eurobarometer 271, 14.

${ }^{19}$ Special Eurobarometer 262, 19.

${ }^{20}$ ABB, Germany: Energy Efficiency Report, last updated January 2011, 3. Retrieved from http://www05.abb.com/global/scot/scot316.nsf/veritydisplay/5793753d3056bfb4c12578640051183f/Sfile/ Germany.pdf on 16.April 2013.

${ }^{21}$ Special Eurobarometer 27I, 14.

${ }^{22}$ Special Eurobarometer 262, 52.

${ }^{23}$ Special Eurobarometer 271, 14. 
energy had more than twice the amount of market share in France than in Germany, but also because France's share of renewable energy as a part of its energy mix had actually been declining over time while Germany's share grew.

In terms of perceptions of nuclear safety, while $45 \%$ of German respondents thought that nuclear plants were a risk to themselves or their family, $65 \%$ of French respondents did so. ${ }^{24}$ As almost four-fifths of France's energy is produced by nuclear energy, this result indicates that French attitudes were not as unanimous as seemed to be suggested by a lack of recent social mobilization. However, this result could also just reflect that, at 58 reactors, French respondents were just more likely to live near a nuclear power plant than Germany's 17 reactors. Also interesting is that, while $58 \%$ of German and French respondents agreed that it was possible to operate a nuclear plant in a safe manner, both countries still fell below the EU average (59\%). ${ }^{25}$ Similarly, only $56 \%$ of German respondents and $50 \%$ of French respondents agreed that their national legislation was sufficient for nuclear safety, but respondents were fairly positive about their national nuclear safety authority's ability to ensure nuclear safety with $55 \%$ of French respondents and $60 \%$ of German respondents agreeing. ${ }^{26}$ However, the results were mixed concerning public trust of companies who operate nuclear power plants. French respondents generally trusted these companies (62\%) but the majority of German respondents (53\%)

\footnotetext{
${ }^{24}$ Special Eurobarometer 271, 21.

${ }^{25}$ Ibid., 25. Spain (55\%) was the only other country with a nuclear power plant to fall below the EU average.

${ }^{26}$ Ibid., 27.
} 
did not trust these companies. ${ }^{27}$ This German result is contrary to the survey's trend that respondents who live in a European country with a nuclear power plant tended to trust these companies and in fact report more positive perceptions of nuclear energy in general. Reflecting its presence in the EU Energy 2020 initiative, over $60 \%$ of French (65\%) and German (61\%) citizens did not believe that radioactive waste can be managed safely regardless of governmental safety regulations. ${ }^{28} \mathrm{~A}$ high percentage of both French and

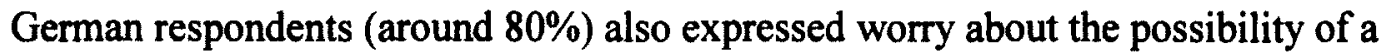
terrorist attack on their nuclear facilities. ${ }^{29}$ Both of these concerns were reflected in the analysis of media coverage in both countries, but this paper does not delve into these issues.

Breaking the trend of results being split on the presence of a national nuclear power plant, whether a country had power plants did not appear to impact on respondents' support for national authority over nuclear policy. 57\% of French respondents and $64 \%$ of German respondents did not think nuclear safety should be left in the hands of national administrations. ${ }^{30}$ This may indicate greater support for EU regulation in these countries. In fact, another question reveals that, Europe-wide, $87 \%$ of respondents supported the EU acting to harmonize legislation and safety standards between member states and a further $88 \%$ believed that the EU should facilitate

\footnotetext{
${ }^{27}$ Special Eurobarometer 271, 28.

${ }^{28}$ Ibid., 29.

${ }^{29}$ Ibid., 30.

${ }^{30}$ Ibid., 54.
} 
cooperation between experts. ${ }^{31}$ The EU would try to act in this capacity following the Fukushima disaster but, as will be shown, it encountered significant resistance from many member states.

In summary, more than half (53\%) of Eurobarometer 271 respondents believed that the risks posed by nuclear energy are greater than the advantages it offers yet one third still saw nuclear energy as more advantageous than risky. ${ }^{32}$ French respondents once again rejected their government's narrative with $56 \%$ of respondents indicating that the risks are greater than the benefits against $33 \%$ of those who thought it is more beneficial. ${ }^{33}$ Similarly, $51 \%$ of German respondents thought of nuclear energy as a risk while $37 \%$ thought of its benefits. ${ }^{34}$ Once again, these results appear contrary to each government's historical responses to anti-nuclear sentiment. A majority of French and German respondents felt that the risks of nuclear energy outweighed its benefits but, while the German government's historical responses seem consistent with its slim majority (51\%) as its nuclear policy has swung back and forth, the French government's historical responses seem almost completely independent of the French public's relatively safer majority (56\%) that were skeptical of nuclear energy. This suggests that institutions play a major role in shaping each government's response, or possibly that electoral timing and a strong elite consensus allowed the French government to weather public disapproval. The French government's refusal to engage meant the decline of the once

\footnotetext{
${ }^{31}$ Special Eurobarometer 271, 53.

${ }^{32}$ Ibid., 17.

${ }^{33}$ Ibid., 18.

${ }^{34}$ Ibid., 18.
} 
prominent French anti-nuclear movement after 1981, and this lack of success could have discouraged the French from mobilizing again despite anti-nuclear sentiment.

The survey period of Special Eurobarometer 324: Europeans And Nuclear Safety, which was a three-year update to Special Eurobarometer 271, was interesting as it covered a time of great debate in Germany about the 2000 phase-out of its reactors. As will be discussed in the next section, while the phase-out had been implemented under the previous government in 2000, the parties that formed the new government (the CDU and FDP) had announced before the 2009 election that they planned to vote for a lifetime extension of German nuclear power plants. ${ }^{35}$ However, despite this debate, the results remained stable since the previous survey.

In terms of the lifetime extension debate, $39 \%$ of Europeans agreed that plants could be extended if they continued to satisfy national and international safety requirements, while $23 \%$ agreed about the impact of more competitive costs and $22 \%$ agreed due to the development of alternative energy sources. ${ }^{36}$ The impact on the development of alternative energy sources was a particularly strong argument in Germany $(39 \%) .{ }^{37}$ However, $19 \%$ of respondents were totally opposed to any lifetime extension strategy with French respondents at $13 \%$ and German respondents at $24 \%{ }^{38}$ While this may not seem like a significant percentage, the question was phrased to ask

\footnotetext{
${ }^{35}$ Special Eurobarometer 324: Europeans And Nuclear Safety. Published March 2010, with fieldwork September - October 2009. Retrieved from http://ec.europa.eu/energy/nuclear/safety/doc/2010 eurobarometer_safety.pdf on 12 February 2013, 8.

${ }^{36}$ Special Eurobarometer 324, 34.

${ }^{37}$ Ibid., 34.

${ }^{38}$ Ibid., 30-31.
} 
what explanation (safety, electricity cost, and alternative energy) would persuade the respondent to support a nuclear plant lifetime extension; the outright refusal to support the extension was a spontaneous answer. Within this opposition, $29 \%$ felt that upgrades cannot ensure an adequate level of safety, while $28 \%$ would rather new power plants be built according to the best available safety design. ${ }^{39}$ Both of these concerns are present in the media analysis.

As in the 2006 results three years previously, almost equal proportions of French respondents agreed and disagreed (43\% and $40 \%)$ that nuclear energy limits the impacts of climate change. Germans responded similarly (with $48 \%$ agreeing while $45 \%$ disagree).$^{40}$ Also constant is that a majority (51\%) of Europeans believed that nuclear risks outweighed its advantages with France (53\%) and Germany (52\%) once again exceeding the EU average. ${ }^{41}$ Yet, there was a decrease of French and European respondents who believed that the risks of nuclear energy outweigh its benefits from 2006 to 2009 (56\% to $53 \%$ and $53 \%$ to $51 \%$ respectively). In terms of the perception of nuclear safety, the majority of respondents in 18 out of $27 \mathrm{EU}$ countries felt that risks are being underestimated. ${ }^{42}$ In France, $58 \%$ of respondents felt that the risk of nuclear power was underestimated versus the $33 \%$ who felt it was overestimated. In Germany, $53 \%$ of respondents felt that the risks were underestimated with $39 \%$ feeling that they were

\footnotetext{
${ }^{39}$ Special Eurobarometer 324, 33.

${ }^{40}$ Ibid., 15.

${ }^{41}$ Ibid., 41.

${ }^{42}$ Ibid., 46.
} 
overestimated. ${ }^{43}$ Similarly to the previous survey, the issue of radioactive waste was a prime nuclear safety issue. Despite the trend of countries with nuclear power plants reporting more positive nuclear perceptions, Germany (70\%) and France (66\%) have similar levels of concern on the disposal of radioactive waste. ${ }^{44}$

Overall, less than $20 \%$ of respondents in Eurobarometer 324 thought that their national share of nuclear energy should be increased. $39 \%$ preferred maintaining it at the current level while $34 \%$ wanted it reduced. ${ }^{45}$ French public opinion showed a marked difference on this point from 2006 with $45 \%$ now wanting the share of nuclear energy in the national energy mix to be reduced in contrast to the relative majority of $49 \%$ three years earlier. ${ }^{46}$ This is consistent with the decrease in the proportion of French respondents who felt that the risks of nuclear energy outweighed its benefits, suggesting that a global nuclear renaissance was underway that was increasing the French public's positive perceptions of nuclear energy. This could be due to growing pride in France's major nuclear industry that, through Areva's industry dominance of all aspects of the nuclear lifecycle, exports advanced nuclear technology around the world. It could also be a result of the nuclear industry's contribution of about $2 \%$ to France's GDP through the creation of jobs and other economic benefits for communities.

Also of interest in these Eurobarometer surveys was their consideration of how attitudes towards nuclear energy are formed. In its assessment of attitude formation

\footnotetext{
${ }^{43}$ Special Eurobarometer 324, 46.

${ }^{44}$ Ibid., 64.

${ }^{45}$ Ibid., 24.

${ }^{46}$ Ibid., 27.
} 
towards nuclear energy, Eurobarometer 271 suggests that personal experiences of nuclear issues and people's level of feeling informed were paramount in determining their stance towards nuclear energy. The survey notes that those who felt informed about nuclear safety were more likely (by 17 percentage points) to think that the advantages of nuclear energy outweighed its risks than those who reported feeling uninformed. ${ }^{47}$ Overall, respondents did not feel informed about safety issues related to nuclear power plants with $26 \%$ feeling completely uninformed and another $50 \%$ feeling not very well informed. In contrast, only $20 \%$ felt fairly well informed and $3 \%$ felt very well informed. ${ }^{48}$ In the French and German cases, $84 \%$ of French respondents felt uninformed while $68 \%$ of German respondents felt so. ${ }^{49}$ This feeling of being informed could be a crucial element of this paper's analysis. As the literature review noted, the technical nature of the nuclear issue means that its discussion is often confined to the bureaucracy and industry. Furthermore, the media coverage in the next chapter reveals that, for example, French citizens have not been informed of some low-level incidents at domestic nuclear plants. This matters because industry and government officials have ownership of the information that describes the impacts of a nuclear incident. This means that the amount of radiation released is not necessarily useful even if the information is made available because the government establishes the level at which radiation is considered 'safe' for humans but the public has no context on what 'safe' means.

\footnotetext{
${ }^{47}$ Special Eurobarometer 271, 19.

${ }^{48}$ Ibid., 43.

${ }^{49}$ Ibid., 44.
} 
In terms of how information is obtained to form these opinions, both French (57\%) and German (49\%) respondents considered scientists to be the most trustworthy authorities on nuclear issues. ${ }^{50}$ This is perhaps related to the technical nature of the issue and the fact that scientists are more likely to be unbiased and credible if they are not associated with the industry or government. Yet the mass media remained the main source of information for respondents, with European respondents saying that they got their information primarily from television ( $87 \%$ ) followed by radio (44\%) and newspapers (37\%). ${ }^{51}$ While some reports suggest that France and Germany may have a higher newspaper consumption than other European states, this point is important to keep in mind as this analysis is based on a medium that may have less than $40 \%$ of the influence shaping the public opinion. Overall, in every country save Finland, citizens felt that the information they receive is insufficient and, while countries with nuclear power plants have slightly more positive opinions, French respondents (72\%) and German respondents $(65 \%)$ still felt that the information they receive is inadequate. ${ }^{52}$ This feeling that the public is not informed or has not received inadequate information could explain the degree to which public opinion has appeared to shift dramatically in the past immediately after a nuclear incident. By way of comparison, when a large-scale oil spill happens, the public is more likely to call for increased regulation and other safety measures rather than an oil phase-out. While this comparison is not perfect, when an incident like Three Mile Island or Chernobyl happens, the public's attitude could be so

\footnotetext{
${ }^{50}$ Special Eurobarometer 271, 52.

${ }^{31}$ Ibid., 46.

${ }^{52}$ Ibid., 48.
} 
responsive to change as they do not have the same degree of knowledge about nuclear energy or its health impacts as they do of the substance that they put in their car on a regular basis.

Reflecting on the overview of the Eurobarometer results in Table 1, it seems that the majority of French, German, and European respondents in general have, at the very least, a reticent attitude towards nuclear energy. These surveys demonstrate that, in the five years prior to the Fukushima accident, French and German public opinion towards nuclear energy was similar in many ways. The most telling finding is that a comparable majority of French and German respondents (53\% and 52\% respectively) believed that the risks outweighed the advantages. ${ }^{53}$ These surveys also demonstrate that public opinions do not necessarily determine government policy. French respondents did not share their government's conviction that nuclear energy was the only French way, nor that it was necessarily the most environmentally friendly. However, there may be a caveat here, as French respondents who wanted to reduce nuclear energy declined three percentage points in three years from 2006 to 2009 so it is possible that it continued to decline for the next two years before the Fukushima disaster. This decline could be an effect of the nuclear renaissance movement and is in fact echoed in the decrease of French (56\% to $53 \%)$ and European (53\% to $51 \%)$ respondents who believed that the risks of nuclear energy outweighed its benefits from 2006 to 2009. Nevertheless, this was a relatively small decrease so it is difficult to accurately assess the public opinion towards nuclear energy prior to the Fukushima disaster.

\footnotetext{
${ }^{53}$ Special Eurobarometer 324, 41.
} 


\subsection{Setting the Stage for France and Germany's Fukushima Reactions}

In examining each country's political institutions and public's attitudes toward nuclear energy, this paper can now describe the context in which the Fukushima disaster occurred in France and Germany.

In France prior to Fukushima, the government controlled all aspects of nuclear energy within its borders through its majority ownership of the utility EDF as well as the company Areva. Its significant investment in these companies and its subsidy of the construction of several power plants combined with the growing global dominance and accompanying economic benefits of its nuclear industry to promote an elite consensus between all political parties (save the EELV) to stay committed to the nuclear course. Indeed, construction began on a new European Pressurized Reactor (EPR) reactor at the Flamanville nuclear power plant in 2007. France's highly centralized structure and lack of legal framework governing its nuclear policy made it resistant to public anti-nuclear sentiment, despite the fact that Eurobarometer surveys establish that at least half of the public was concerned about the risks of nuclear energy. However, a decrease in antinuclear sentiment expressed in these surveys from 2006 to 2009 suggests that the French public was becoming more positive about nuclear energy over time, which means that the public was possibly even more positive towards nuclear energy at the time of the Fukushima disaster. It remains unclear however whether this positive trend would have crossed the majority threshold of French respondents who felt that the nuclear risks outweighed its benefits.

In Germany prior to Fukushima, control of the nuclear industry was divided between the federal government, who was at the time pro-nuclear as evidenced by its 
2009 election commitment to extend nuclear plants' lifetimes, and state governments, of which some were decidedly anti-nuclear. Nevertheless, control of the nuclear course largely resided with the federal government. The federal government was quite close with the four major power companies in Germany, E.ON, Vattenfall, RWE, and EnBW, due to the 2010 lifetime extension and several state governments owned significant shares in these companies, such as Baden-Württemberg's major stake in EnBW. There was certainly not an elite consensus in Germany at this time, as the SPD and Greens had been part of the previous effort in 2000 to phase-out nuclear energy while the CDU and FDP were the parties who implemented the 2010 lifetime extension. However, the previous agreement to phase-out nuclear energy had already been fully planned out before the lifetime extension, so a phase-out remained a possibility in the collective German consciousness simply because it had been done before. While Germany's Atomic Energy Act provided a legal framework for anti-nuclear activists to use to advance their cause, it was really only useful when a nuclear power plant was under construction. Nevertheless, anti-nuclear activists and members of the public made their displeasure known following the 2010 lifetime extension for nuclear power plants by organizing protests throughout September and October. This reflects the Eurobarometer surveys' indication that a majority of German respondents felt that nuclear energy's risks outweighed its benefits.

Following this mapping of the domestic context of each country prior to the Fukushima disaster, this paper will now begin its media analysis of coverage of the Fukushima disaster and the domestic nuclear debates from 11 March to 18 June 2011. 


\section{Chapter: French and German Media Coverage, 11 March - 18 June}

This chapter will examine the coverage of the Fukushima crisis in Le Monde and Süddeutsche Zeitung, along with the four supplemental newspapers, beginning first with an overview of this media coverage before analyzing this coverage within five specific themes.

The Fukushima Daiichi (or No. 1) nuclear power plant is located in the Fukushima Prefecture of Japan. It has six boiling water reactors, whose electricity generation capacity made Fukushima one of the largest nuclear power plants in the world. Opened in 1971, Fukushima Daiichi is operated by the Tokyo Electric Power Company (TEPCO). Fukushima Daiichi has a smaller sister plant, Fukushima Daini (or No. 2), which is located to the south and also run by TEPCO.

On Friday, 11 March 2011, a 9.0 magnitude earthquake struck off the east coast of Japan. The earthquake caused considerable damage, and prompted a 15-metre tsunami to sweep over the Sendai region. This double disaster resulted in over 19,000 deaths with heavy damage to regional infrastructure. Eleven regional reactors at four nuclear power plants were operational at the time and were shut down automatically after the earthquake. However, the tsunami disrupted the power supply and cooling systems of Units 1-3 of Fukushima Daiichi, which caused a nuclear accident through the more-orless meltdown of these three reactors within three days. Unit 4 became a problem soon after. These details of course were only finalized months after the Fukushima disaster. The initial reporting of the events was incomplete and often inaccurate but prevalent throughout the media, as the internet allowed minute-by-minute reporting of details as they became known. 


\subsection{Fukushima Media Coverage and Immediate State Reactions}

As the Fukushima situation continued to be fluid for up to six months with reports of explosions or melting, both Le Monde and Süddeutsche Zeitung had weekly reports to update their readership on the situation (and often daily reports during the survey period). While this analysis is not explicitly interested in the events reporting of the Fukushima incident, the early stage of reporting is interesting as its quantity and tone can reveal much about each national narrative about nuclear energy.

From a purely quantitative assessment, the Fukushima disaster appears to have prompted far more discussion in Germany than France. While these results are conditional on the quality of data available in the Factiva and Eureka.cc databases respectively, as can be seen in Table 1 and Table 2 below, Süddeutsche Zeitung produced considerably more articles than Le Monde throughout the study period from 11 March to 18 June 2011. In total, Süddeutsche Zeitung produced $77.1 \%$ more articles on the key words "Fukushima," "Nuclear," or "Atom" (and their linguistic variants) over the study period than Le Monde. In March, this included $92.3 \%$ more than the French media and 87.3\% more in April. This percentage dropped to $65.4 \%$ in May, and finally $20.9 \%$ in June.

Fukushima Coverage by Le Monde

\begin{tabular}{|c|c|c|c|c|c|}
\hline \multirow{2}{*}{$\begin{array}{l}\text { Le Monde } \\
\text { LeMonde.fr }\end{array}$} & 388 & 252 & 188 & 115 & 943 \\
\hline & & & & & \\
\hline Total & 634 & 426 & 292 & 187 & 1539 \\
\hline
\end{tabular}

Table 2 Articles in Le Monde from 11 March to 18 June 2011 


\section{Fukushima Coverage by Süddeutsche Zeitung}

\begin{tabular}{|c|c|c|c|c|c|}
\hline $\begin{array}{l}\text { Suddeutsche } \\
\text { Zeitung }\end{array}$ & 915 & 639 & 397 & 186 & 2137 \\
\hline $\begin{array}{l}\text { Süddeutsche } \\
\text { Zeitung Online }\end{array}$ & & & & & \\
\hline Total & 1219 & 798 & 483 & 226 & 2726 \\
\hline
\end{tabular}

Table 3 Articles in Saddeutsche Zeitung from 11 March to 18 June 2011

This discrepancy could be a result of the Süddeutsche Zeitung's larger circulation (and theoretically more resources). Interestingly however, Le Monde's online coverage quantitatively exceeded that of Süddeutsche Zeitung in April, May, and June. Le Monde particularly offered more online chats with experts during which any user could directly ask questions about the situation in Japan, radiation, and France's nuclear facilities or policy, among others.

In consideration of the four newspapers that this paper is using to mitigate any editorial bias in Le Monde or Süddeutsche Zeitung, Table 4 presents their quantity of coverage over the same period of study. The first item of note is the discrepancy in quantity between the two primary newspapers and the four secondary newspapers. The fact that Le Monde and Süddeutsche Zeitung have a far greater quantity of articles on the nuclear issue is likely more a result of their circulation, which was a consideration in selecting them, and thus funding for more resources than any special interest in Fukushima compared to the other newspapers. For example, Süddeutsche Zeitung has a circulation of approximately 1.1 million while Die Welt has a circulation of only about 200,000 . 


\section{Fukushima Coverage by Supporting Sources}

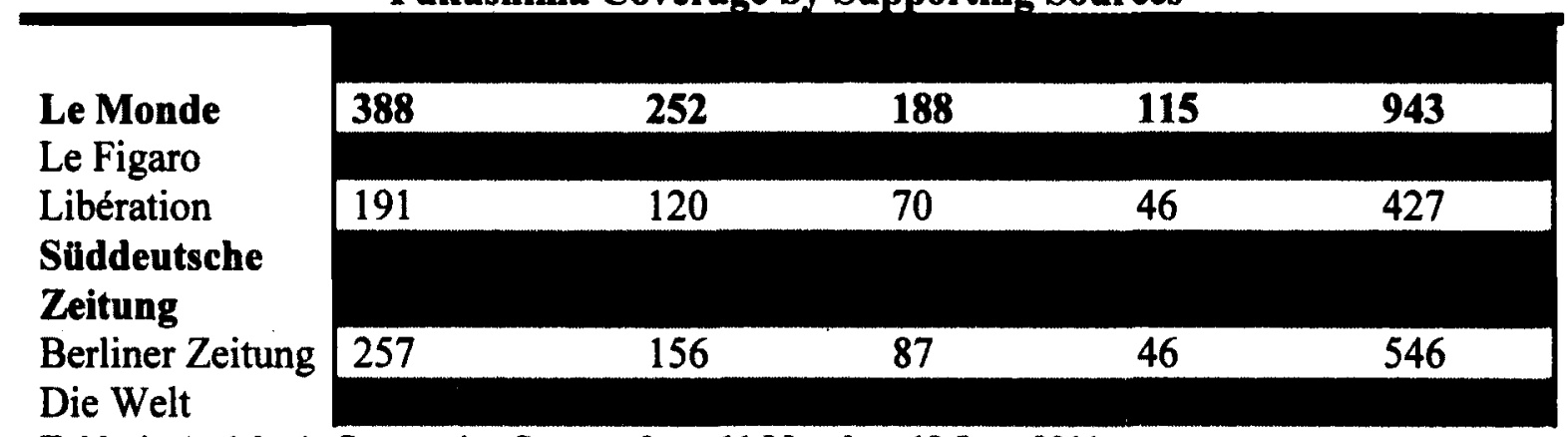

Table 4 Articles in Supporting Sources from 11 March to 18 June 2011

What is of interest however is that the Fukushima coverage appears to follow similar decline trends in each newspaper by month. While one needs to keep in mind that only half of March and June was examined, Le Monde's coverage drops $53.9 \%$ from March to April, 34\% from April to May, and 63.4\% from May to June (total decline 237.3\%). This compares to Le Figaro's $47.8 \%, 40 \%$, and $47.7 \%$ respective declines (total decline $205.6 \%$ ) as well as Libération's $59.1 \%, 71.4 \%$, and $52.1 \%$ respective declines (total decline 315\%) once scale is taken into account. While Süddeutsche Zeitung's sheer circulation does skew the comparison somewhat, its coverage drops $43.2 \%$ from March to April, $60.9 \%$ from April to May, and $113.4 \%$ from May to June (total decline $391.9 \%$ ). This is comparable to Berliner Zeitung's $64.7 \%, 79.3 \%$, and $89.1 \%$ respective declines (total decline $458.7 \%$ ) as well as Die Welt's $55.9 \%, 15.3 \%$, and $69.5 \%$ (total decline 384.5\%). This comparison is also interesting, as it appears that newspapers with a left orientation, particularly Libération and Berliner Zeitung, appear to have the largest overall decline. This is odd as the political left is typically more likely to offer antinuclear sentiment, so it is strange that this coverage would decline when faced with a prime rallying issue like Fukushima. It is possible that the Fukushima saturation of media coverage caused these smaller newspapers to search for other issues to differentiate themselves, but this paper can offer no definite explanation on this point. 
The declining quantity of articles reflects some waning interest on the issue. This is reflected in some decline in public demonstrations as well (with some exceptions). For example, on 10 April, approximately 3800 people from France, Germany and Switzerland gathered to call for the closure of Fessenheim. About 10,000 people attended a similar event on 20 March. ${ }^{\prime}$ Some German media coverage criticized this decline with a comparison between radioactive half-lives and political half-lives. Less than a month after the beginning of the Fukushima disaster, politicians who had promised a phase-out began to start uttering 'buts' as Christian Democrat (CDU) and Free Democratic Party (FDP) politicians assumed that the necessary political fallout was settled through their poor performance in the March state elections. ${ }^{2}$

Key dates throughout this survey period include 11 March, the day of the disaster; 14 March, the day the German three-month suspension was announced; German state elections that were held immediately post-Fukushima on 20 and 27 March; 11 April, when the Fukushima incident was upgraded to a Level 7 on the International Nuclear Event Scale, which meant that Fukushima joined Chernobyl as the only two Level 7 incidents recorded; 26 April, the $25^{\text {th }}$ anniversary of the Chernobyl disaster; 30 May, the day Germany announced its nuclear exit; 6 June, the day Germany's nuclear exit became law; and 17 June, the day when Sarkozy and Merkel held a joint conference in Berlin. While not all of these dates are directly referenced in this thematic analysis, the events are important as they maintained media attention throughout the four-month period.

\footnotetext{
'LeMonde.fr with Agence France-Presse (AFP), "Des milliers de manifestants demandent l'arrêt de la centrale de Fessenheim," LeMonde.fr, 11 April 2011, Eureka.cc.

2 "Fukushima, verweht; Von Heribert Prantl," Süddeutsche Zeitung, 11 April 2011, Factiva.
} 
Prior to the news breaking of Fukushima, there was not consistent news coverage of nuclear issues in Germany. Some environmental groups were maintaining weekly vigils in protest of Merkel's lifetime extension from six months prior, but attendance was comparatively low and they did not receive a great deal of media coverage. For example, there were weekly vigils outside Isar since 1 September $2010 .^{3}$ In contrast, nuclear energy is such a large industry in France that media coverage was more consistent, albeit with an economy or industry approach and not as part of a debate on nuclear energy. Ironically, prior to news breaking on events in Japan on 11 March, there was an article discussing whether the state was engaging in a protectionist policy in favour of nuclear energy given government moves to discourage the growth of the solar industry. ${ }^{4}$

Early coverage by Le Monde and Süddeutsche Zeitung focused more so on the devastation wrought by the earthquake and tsunami. ${ }^{5}$ However, from the beginning, Süddeutsche Zeitung had more coverage of the nuclear situation and reported on it sooner. ${ }^{6}$ Süddeutsche Zeitung Online prepared a timeline of the events as they unfolded in

\footnotetext{
${ }^{3}$ Christian Sebald, "Draußen vor dem Tor; Die Schauspielerin Mira Neumeier organisiert seit September wöchentliche Mahnwachen vor Isar 1- die Resonanz ist groß," Süddeutsche Zeitung, 21 March 2011, Factiva.

${ }^{4}$ Le Monde.fr with Agence France-Presse (AFP), "Ségolène Royal fait de la résistance sur le photovoltaique," Le Monde.fr, 11 March 2011, Eureka.cc.

5 "Direct : les côtes japonaises frappées par un tsunami," Le Monde.fr, 11 March 2011, Eureka.cc; "Les côtes japonaises frappees par un tsunami," Le Monde.fr, 12 March 2011, Eureka.cc; "Naturkatastrophe; Tsunami an Japans Küste," Süddeutsche Zeitung Online, 11 March 2011, Factiva; "Dokumentation; Die weltweit schwersten Erdbeben," Süddeutsche Zeitung Online, 11 March 2011, Factiva; "Erdbeben in Japan; Sorge um Japans Wirtschaft erfasst Finanzmărkte," Süddeutsche Zeitung Online, 11 March 2011, Factiva; "Tsunami-Vorhersage; Kartographie der Katastrophe," Süddeutsche Zeitung Online, 11 March 2011, Factiva; Katharina Riehl, "Erdbeben und Internet; Hilfe, Japan, melde dich," Süddeutsche Zeitung Online, 11 March 2011, Factiva.

6 "Bilder des Erdbebens; Gefangen im braunem Schlamm," Süddeutsche Zeitung Online, 11 March 2011, Factiva; "Protokoll; "Das Schlimmste, was ich je erlebt habe"," Süddeutsche Zeitung Online, 11 March 2011, Factiva.
} 
Japan, while also consulting with German experts on the state of the Fukushima plant, who cautioned that the plant was running on battery power that would run out after a few hours. ${ }^{7}$ Also unlike Le Monde, Süddeutsche Zeitung began the theme of domestic nuclear safety immediately on 11 March. $^{8}$ Its early coverage drew parallels to the Three Mile Island disaster in 1979 , which arose due to cooling problems, and questioned the safety of German nuclear power plants, as every plant's weakness is the electricity supply to the cooling systems. ${ }^{9}$ Other articles questioned the credibility of the information provided by the Japanese government given their previous lack of transparency in other nuclear incidents and also indicated that it was likely that Fukushima would be classified at the highest level possible for a nuclear incident. ${ }^{10}$

Le Monde began covering the nuclear emergency on 12 March. ${ }^{\text {" }}$ This slight delay may be due to the fact that 11 March was a Friday and the nuclear situation did not truly escalate until the morning of $12 \mathrm{March}$, which was a Saturday and therefore journalists are less likely to do a full-coverage analysis. From this point, the unfolding

\footnotetext{
7 "Erdbeben in Japan; AKW nur noch mit Batterie gekuhlt," Süddeutsche Zeitung Online, 11 March 2011 , Factiva.

${ }^{8}$ Michael König, "Erdbeben in Japan: AKW beschadigt; "Tschernobyl ist die richtige Assoziation"," Süddeutsche Zeitung Online, 11 March 2011, Factiva.

9 "Drohender Atom-GAU in Japan; Wie sicher sind die deutschen AKWs?" Süddeutsche Zeitung Online, 12 March 2011, Factiva; Marlene Weiss, "Gegen alle Regeln; Japans Atomkraftwerke mussen seit der Katastrophe von Kobe viel aushalten können, aber für ein Erdbeben der Starke 8,9 waren auch sie nicht gerilstet," Süddeutsche Zeitung, 12 March 2011, Factiva.

${ }^{10}$ Weiss, "Gegen alle Regeln," 12 March 2011 ; Christopher Schrader, "Super-GAU im AKW Fukushima; "Die Kernschmelze ist nicht mehr zu stoppen, wenn ..." Süddeutsche Zeitung Online, 12 March 2011, Factiva.

"LeMonde.fr with Agence France-Presse (AFP) and Reuters, "Japon : scènes de désolation au lendemain du séisme," LeMonde.fr, 12 March, Eureka.cc.
} 
disaster and details were reported similarly between both newspapers albeit that the Süddeutsche Zeitung had a greater quantity of coverage.

In terms of the coverage of the supplemental newspapers, they too followed a similar path of events reporting as the two primary sources and described the Fukushima disaster and its domestic ramifications in each respective state in similar ways. ${ }^{12}$ Therefore, as these supplemental newspapers are only being used to mitigate any editorial bias of the primary two newspapers, these supplemental newspapers and their articles will only be referenced if they offer a different perspective or if their quantity of articles covering a certain theme was higher than the primary two sources. Using this approach, this paper cites the conservative newspapers, Le Figaro and Die Welt, far more than their left counterparts, Libération and Berliner Zeitung. This is interesting, as these leftoriented newspapers appeared to have the largest overall decline of media coverage of the Fukushima disaster and the anti-nuclear debate over the study period. Therefore, their comparative lack of variance that was needed to include them more in this analysis could simply be due to a reduced sample size.

\subsection{Transparency and Democracy Concerns: Nuclear Industry and Government}

\section{as 'Too Close for Comfort'}

As discussed in the literature review, anti-nuclear movements in both countries often criticized their governments for their lack of transparency in nuclear policymaking

\footnotetext{
${ }^{12}$ Marc Mennessier, "Fukushima : la situation serait plus grave que prévu,"Le Figaro, 18 May 2011 , Factiva; Jean-Claude Jancovici, "La main invisible de la radioactivite," Le Figaro, 4 April 2011, Factiva; Fabrice Nodé-Langlois, "L'avenir du nucléaire civil en suspens," Le Figaro, 28 March 2011, Factiva; Nicholas Brautlecht, "Japan und die Atomkatastrophe: Fukushima auf gleicher Stufe mit Tschernobyl - Die Not der Evakuierten - Die Folgen fur die Wirtschaft - Gesundheitsrisiken für die Menschen - So schlimm wie Tschernobyl," Die Welt, 13 April 2011, Factiva; Nicholas Brautlecht, "Tokio greift nach Tepco,"Die Welt, 30 March 2011, Factiva; Kerstin Krupp and Nicolas Garz, "Berlin. "Lăsst sich die Atomkatastrophe in Japan noch abwenden? Nach Ansicht von..." Berliner Zeitung, 18 March 2011, Factiva; Sylvestre Huet, "Fukushima. Repères," Libération, 26 May 201 1, Factiva.
} 
and how this lack of transparency manifested itself in a secretive relationship with nuclear operators. While most of the literature attributes this secretive relationship to the technical nature of nuclear energy, there is also the issue of nuclear dualism or that governments need to be closely involved in their domestic nuclear programs due to the destructive potential of the technology. For similar reasons, governments may argue that they cannot be overly transparent about this dangerous technology in case it should fall into the wrong hands. Therefore, if a state has a civilian nuclear energy program, it falls to reason that it would have a close relationship with the power companies operating its nuclear power plants. Nevertheless, concern regarding the perceived close relationship between government and industry manifested itself in both Le Monde and Süddeutsche Zeitung. This concern can be grouped in three main ways: concerns about the transparency and lack of democracy within the nuclear industry, concerns about the French or German government's involvement in the industry, or broader concern about the global governance of nuclear energy. These three themes will be applied first in the French case and then the German one before analyzing the implications of these themes for this paper's overall argument.

\subsubsection{French Concerns about National Government and Industry Collusion}

In terms of concerns about the French government's involvement in the industry, media coverage focused on democracy and transparency concerns, the government's response to Fukushima with seemingly industry interests, their ruling in favour of Electricité de France (EDF) on wholesale electricity, and its close involvement in Areva. Le Monde's media coverage decried what it perceived to be government attempts to contain any nuclear debate to technical issues as weakening democracy and subverting 
transparency. ${ }^{13}$ Beyond these technical issues, some political representatives argued that nuclear energy is an important societal choice and it can only be chosen through democratic process. ${ }^{14}$ For one author, the closed-off culture of the nuclear industry allowed it to collude with government without scrutiny; Tassel pointed to the behavior of TEPCO following Fukushima as a demonstration of the need for public oversight, transparency, and independent research. ${ }^{15}$ In other words, through the state's ownership of nuclear energy, the power plant operator's responsibility is diminished. ${ }^{16}$ Another article argued that, just as a bank too big to fail should not exist, nuclear power plants that are too big and dangerous to fail should not exist; it suggested that the prospect for profit and economic growth encouraged the collusion of government and industry representatives, damaging the democracy process. ${ }^{17}$ This argument became more poignant when it was revealed that a month before the earthquake and tsunami, the oldest of the six Fukushima reactors was granted a 10-year extension despite repeated safety warnings to the Japanese government. ${ }^{18}$ Others argued that environmental issues are

\footnotetext{
${ }^{13}$ Catherine Mary, "Confisquer le débat sur les enjeux de la science, c'est affaiblir la démocratie," LeMonde.fr , 9 June 2011, Eureka.cc. On the opposing side, another article dismisses calls for a nuclear exit on the basis of poor information offered by opponents. He argues that calls for 'independent' assessments are flawed as it is only officials with the proper expertise and equipment that can accurately provide this information. Jacques Treiner, "Nucléaire : rétablissons quelques verities," LeMonde.fr, 6 May 2011, Eureka.cc.

${ }^{14}$ Amaud Montebourg, "'Le nucléaire est dépassable"," LeMonde.fr, 14 April 2011, Eureka.cc.

${ }^{15}$ Stéphane Tassel, "Nous devons reconquérir ce qui nous a fait choisir le service public..." LeMonde.fr, 5 May 2011 , Eureka.cc.

${ }^{16}$ Jean-Jacques Delfour, "Nucléaire et jouissance technologique," LeMonde.fr, 12 April 2011, Eureka.cc.

${ }^{17}$ Marc Humbert, "Japon : alerte verte et rouge," LeMonde.fr, 23 March 2011, Eureka.cc.

${ }^{18}$ Antoine Bouthier, "Nucléaire : le Japon avait été alerté d'irrégularités à Fukushima," LeMonde.fr, 23 March 2011, Eureka.cc.
} 
issues of democracy and that, without democracy, nuclear energy promotes a dangerous fantasy of technical mastery over nature. ${ }^{19}$

Other articles used a 'public accountability' approach with 'runaway' or 'devil's bargain' undertones. They presented a kind of inverse 'nuclear dualism,' with all positive connotations removed to emphasize that the damaging potential of nuclear energy was equal regardless of its intended usage (military or civilian). Both French and German writers accused their governments of 'worshipping the atom;' national scientists and politicians underestimated the danger due to their blind faith in technology, while the industry sought to maximize profits through reducing costs, compromising security, and underestimating risks. This perspective argued that Fukushima was not a disaster arising from chance but rather through the government's attempt to blame a natural disaster for the serious technical failures that come from the carelessness and negligence of the operator (in this case, TEPCO). ${ }^{20}$ They criticized the French government's strategy of first trying to minimize the accident itself despite other international experts' assessments, before trying to condemn opponents as 'indecent' of the suffering of the Japanese people when it became apparent that the term 'disaster' could not be avoided. ${ }^{21}$ Another article pointed out that France's nuclear workforce comes from the same

\footnotetext{
19 "Après Fukushima : "l'écologie est la plus grande des nécessités dans nos démocraties"," LeMonde.fr, 5 April 2011, Eureka.cc.

${ }^{20}$ Delfour, "Nucléaire et jouissance technologique," 12 April 2011.

${ }^{21}$ When news of Fukushima first broke, French government spokesmen initially condemned opposition leaders who tried to restart the nuclear debate in France of acting 'indecently' to take advantage of Japanese suffering for their own political goals. Géal François, "Il faut sortir de la religion de l'atome," LeMonde.fr, 18 March 2011, Eureka.cc.
} 
universities to work in the same isolated industry, creating a homogenous subculture that made resistance or change unlikely. ${ }^{22}$

Running parallel to these refurbished packages was the emergence of a new package, 'real risk.' One article acknowledged that the assessment of nuclear risk is always difficult, and it represents a communications shift for governments from describing their plants as "totally safe" to discussions of how to improve technology to lower the risk. ${ }^{23}$ As opposed to the nuclear industry's inexperience at Three Mile Island in 1979 or the Soviet Union's excess at Chernobyl in 1986, Fukushima happened to a mature nuclear industry in one of the foremost economic and technological powers in the world. This led to some concluding that, while France and Germany have legitimate reason for pride in their technical prowess, the magnitude of the impacts of nuclear accidents means that the risks cannot be acceptable or sustainable. ${ }^{24}$ Echoing the Eurobarometer results, LeMonde.fr readers who lived near a nuclear power plant considered themselves ill-informed about the risks, but found their discomfort often subsides into resignation. ${ }^{25}$ Similarly, others criticized the nuclear 'dogma' of infallibility and that when the nuclear industry realizes that it can no longer deny the 'residual risks',

\footnotetext{
22 Jeanne Rubner, "Angst vor Westwind; Im französischen Fessenheim, direkt an der Grenze, steht eine altersschwache Atomanlage. Aber weder dort noch im Rest des Landes zweifeln die Menschen an der Kernkraft," Süddeutsche Zeitung, 31 March 2011, Factiva.

${ }^{23}$ Patrick Lagadec, "Comment piloter le monde à l'heure des "mégarisques" et "mégacrises"?" LeMonde.fr, 9 May 2011, Eureka.cc.

${ }^{24}$ Jean-Paul Huchon, President of the Regional Council of Ile-de-France, "Pour sortir du nucléaire, il faut d'abord réussir la conversion énergétique," LeMonde.fr, 6 April 2011, Eureka.cc. Eureka.cc.

25 “"'Quand on vit près d'une centrale nucléaire, on vit avec le risque"," LeMonde.fr, 16 March 2011,
} 
it moves to blacklist alternative energy solutions. ${ }^{26}$ This idea harkens back to the 11 March article, prior to the breaking of the Fukushima story, which discussed the state's move towards discouraging the growth of the solar industry. ${ }^{27}$

Le Figaro's coverage appears to emphasize that there needs to be more understanding of the nuclear risks. For example, an interview with Jacques Repussard, director of the Institute for Radiological Protection and Nuclear Safety, indicated that the statistical probability of a serious nuclear accident was on average once a decade worldwide ${ }^{28}$ Conversely, Libération's coverage appears to try to emphasize that French risks were higher than commonly represented by the government. For example, one article stated that, accordingly to statistical probability, it is likely that a major incident will occur in one of the EU's 143 reactors during the life of the current nuclear fleet and there is a $50 \%$ chance that it would happen in one of France's 58 reactors. ${ }^{29}$

There was criticism of the French government's approach to the Fukushima disaster in terms of its mobilization, not to protect people from the dangers of nuclear energy, but rather to protect the nuclear industry from the criticism of the people. In other words, opponents argued that the government focused on protecting the health of Areva

\footnotetext{
${ }^{26}$ Ulrich Beck, "C'est le mythe du progrès et de la sécurité qui est en train de s'effondrer," LeMonde.fr, 25 March 2011, Eureka.cc.

${ }^{27}$ Le Monde.fr with Agence France-Presse (AFP), "Ségolène Royal fait de la résistance," 11 March 2011.

${ }^{28}$ Interview with Jacques Repussard by Marc Mennessier, "Accident nucléaire : « II faut imaginer l'inimaginable "," Le Figaro, 18 June 2011, Factiva.

${ }^{29}$ Bernard Laponche, “Accident nucléaire : une certitude statistique," Libération, 3 June 2011, Factiva.
} 
and EDF as opposed to the French public. ${ }^{30}$ On this point, there was a court case

complaining that the government concealed the impact of Chernobyl's fallout in France. ${ }^{31}$

Europe Écologie - Les Verts (EELV) representatives also condemned the government's

'indecency' of acting with false sympathy for Japan while initially refusing to

acknowledge Fukushima as a disaster as well as touting the superiority of French

technology over Japanese technology, given Areva's disastrous record of defects, delays,

and cost overruns. ${ }^{32}$ Others criticized the government's 'progress' package as it is seen as

unquestionable dogma by the political elite. Some anti-nuclear opponents further

complained that rational discussion is impossible and opponents are immediately

ostracized, such as when the EELV were booed in the National Assembly when they

dared to question France's nuclear policy after the Fukushima disaster. ${ }^{33}$

This newspaper coverage also contained discussions regarding who should pay

for a nuclear accident and specifically whether the industry should be insured. The

\footnotetext{
${ }^{30}$ Noèl Mamère, MP (EELV), "Est-ce indécent de demander un débat public sur la sortie du nucléaire ?" LeMonde.fr, 23 March 2011, Eureka.cc.

${ }^{31}$ LeMonde.fr with Agence France-Presse (AFP), "Tchernobyl : la cour d'appel examine un arrêt de l'enquête en France," LeMonde.fr, 31 March 2011, Eureka.cc.

${ }^{32}$ In response to the French government's accusation that anti-nuclear opponents were acting 'indecently' in trying to capitalize on the suffering of the Japanese government, opposition leaders used the term 'indecent' in its response to the government. Mamère, "Est-ce indécent de demander un débat?" 23 March 2011; Stéphane Lhomme, "Crise nucléaire : le gouvernement français victime du " syndrome MAM," Le Monde, 15 March 2011, Eureka.cc. Lhomme also lists several nuclear incidents in France including partial meltdowns at the Saint-Laurent (Loir-et-Cher) reactor in 1969 and 1980, the narrowly escaped disaster at the Blaye (Gironde) reactor after seemingly impossible floods, and how the EDF needed to short down several reactors during the heat wave of 2003 while eventually having to water down Fessenheim to avoid an accident. He also notes the serious leak of uranium at the Tricastin nuclear site, which made world headlines and caused local growers to change their name to avoid losing market share.

${ }^{33}$ Beck, "C'est le mythe du progrès," 25 March 2011.
} 
articles refer to the banking and oil industries that were subject to new insurance requirements after major disasters in each respective sector. ${ }^{34}$

France uses its nuclear energy as more than just a power source but a major export as well. For France, the nuclear industry is high tech, which allows its industry to have a virtual monopoly on this industry segment. ${ }^{35}$ This led to a closer relationship between government and industry, as Sarkozy himself promoted Areva abroad. ${ }^{36}$ This close relationship led to accusations of favouritism as the French government ruled in favour of EDF's recommendation that it sell up to $25 \%$ of its electricity to its competitors at a price of 40 euros per megawatt hour from 1 July 2011, and 42 euros from 1 January 2012. ${ }^{37}$ In November 2010, a draft law was implemented to revamp the electricity market in order to promote competition amongst energy suppliers in France. ${ }^{38}$ EDF's competitors wanted to benefit from a much lower price (given that nuclear energy is considered 'cheap') under this new legal framework, which took effect on 1 July $2011 .{ }^{39}$ EDF's competitors, particularly GDF Suez, wanted access to wholesale prices, and therefore access to the current selling price of nuclear electricity, arguing that it should be 35 euros

\footnotetext{
${ }^{34}$ François Dauphin, "Faut-il assurer le nucléaire ?", LeMonde.fr, 6 April 2011, Eureka.cc.

${ }^{35}$ Jean-Paul Biberian, "L'énergie nucléaire est-elle nécessaire ?" LeMonde.fr, 1 April 2011, Eureka.cc.

${ }^{36}$ Rubner, “Angst vor Westwind," 31 March 2011.

${ }^{37}$ LeMonde.fr with Agence France-Presse (AFP), "L'Etat arbitre en faveur d'EDF sur le prix de l'électricité," LeMonde.fr, 19 April 2011, Eureka.cc.

${ }^{38}$ Jean-Michel Bezat, "Electricité : la nouvelle loi va-t-elle entraîner une hausse des prix ?" LeMonde.fr, 19 May 2011, Eureka.cc.

${ }^{39}$ LeMonde.fr with Agence France-Presse (AFP), "L'Etat arbitre en faveur d'EDF,"19 April 2011.
} 
per megawatt hour. ${ }^{40}$ This producer price was guarded like a state secret; one article accuses Sarkozy of keeping this secret because if the French were to pay the unsubsidized price, their nuclear faith would falter. ${ }^{41}$ However, sources claimed that the Energy Regulatory Commission did not endorse the government tariff and recommended a range of 36 to 39 euros per MWh. ${ }^{42}$

The French government was also the mediator in the continuing conflict between Areva and EDF on uranium enrichment. ${ }^{43}$ EDF's CEO Henri Proglio had a history of questioning Areva, but Areva's CEO Anne Lauvergeon rejected rumours that there was tension between the two. ${ }^{44}$ However, Lauvergeon also objected to EDF being part of the board managing Areva's IPO.$^{45}$ As Areva is a state-owned company, Lauvergeon was perhaps too independent for Sarkozy. While MPs from four parties wrote a letter to Le Monde advocating her continued tenure as Areva's CEO, it was announced on 16 June

\footnotetext{
${ }^{40}$ LeMonde.fr with Reuters and Agence France-Presse (AFP), "Le gouvernement promet un tarif d'électricité regale," LeMonde.fr, 20 April 2011, Eureka.cc; Frédéric De Monicault, "Prix de l'électricité : GDF Suez très mécontent," Le Figaro, 20 April 2011, Factiva.

${ }^{41}$ Michael Klăsgen, "Zweifelnde Franzosen; Die Mehrheit würde gern aus der Atomkraft aussteigen. Wenn sie nur nicht so billig ware," Süddeutsche Zeitung, 16 April 2011, Factiva.

${ }^{42}$ LeMonde.fr with Agence France-Presse (AFP), "La Commission de régulation de l'énergie refuse d'entériner le prix de l'énergie," LeMonde.fr, 18 May 2011, Eureka.cc.

${ }^{43}$ LeMonde.fr with Agence France-Presse (AFP), "Areva aurait demandé à l'Etat d'agir dans son conflit avec EDF," LeMonde.fr, 22 March 2011, Eureka.cc.

${ }^{44}$ LeMonde.fr with Agence France-Presse (AFP), "Areva appelle à une "refondation" de sa relation avec EDF," LeMonde.fr, 22 March 2011, Eureka.cc.

${ }^{45}$ LeMonde.fr with Agence France-Presse (AFP) and Reuters, "Areva prêt à réfléchir à une introduction en Bourse," LeMonde.fr, 22 March 2011, Eureka.cc; LeMonde.fr with Agence France-Presse (AFP), "Areva : l'Etat "essaie" de réaliser l'augmentation de capital d'ici fin 2010," LeMonde.fr, 22 March 2011, Eureka.cc; LeMonde.fr with Agence France-Presse (AFP), "L'augmentation de capital d'Areva repoussée," LeMonde.fr, 22 March 2011, Eureka.cc.
} 
that she would be replaced by Luc Oursel, former head of marketing and projects. ${ }^{46}$ While she had wanted to take a third term, Sarkozy had been rumoured to want to replace her for more than a year. There was also the issue of her tense relationship with Henri Proglio, EDF CEO, who was also a close friend of Sarkozy. The state had encouraged EDF and Areva to work more closely together, but Lauvergeon advocated for Areva's independence. While there were some management issues, including the loss of a $\$ 20$ billion contract in Abu Dhabi as well as additional costs and delays in the EPR pressurized water reactor, many predicted Lauvergeon would continue on as CEO as her expertise would be useful in a post-Fukushima climate. ${ }^{47} \mathrm{~A}$ Libération article condemned the close relationship between the government and industry in the post-Fukushima climate as essentially, "EDF will police itself."

French media coverage also expressed a broader concern about the global governance of nuclear energy. As the extent of the Fukushima disaster became apparent, there were reports that nuclear industry representatives were worried that nuclear governance would be shifted from the national level, at which they enjoy a virtual fiefdom, to a supranational organization. ${ }^{49}$ Some French coverage argued that Fukushima

\footnotetext{
${ }^{46}$ UMP, NC, PS and PC MPs, "Ne pas démanteler Areva," LeMonde.fr, 6 June 2011, Eureka.cc; Francois de Beaupuy, "Areva's Lauvergeon Denied Third Term as France Names Oursel as New Chief," Bloomberg, 17 June 2011. Retrieved from http://www.bloomberg.com/news/2011-06-17/areva-slauvergeon-denied-third-term.html on 23 January 2013; LeMonde.fr with Reuters, "Anne Lauvergeon serait remplacée par Luc Oursel à la tête d'Areva," LeMonde.fr, 17 June 2011, Eureka.cc.

${ }^{47}$ Michael Klassgen, "Atomic-Anne muss gehen; Frankreichs Präsident hat schon oft signalisiert, ArevaChefin Lauvergeon ablosen zu wollen. Nun ist seine Entscheidung gefallen," Süddeutsche Zeitung, 17 June 2011, Factiva; Frédéric De Monicault, "«Atomic Anne»,"Le Figaro, 17 June 2011, Factiva.

${ }^{48}$ Alexandra Schwartzbrod, "Le nucléaire français à l'ère du soupcon," Libération, 11 May 2011, Factiva.

${ }^{49}$ Eric Hervé and Pascal Tréhet, "Pour une gestion supranationale de la sûreté nucléaire," LeMonde.fr, 6 April 2011, Eureka.cc.
} 
highlighted the need for better international communication and cooperation in research and resources as, while the French government provided regular information updates, these updates were dependent on the quality of information given by the Japanese government. ${ }^{50}$ Other coverage argued that more extensive reform is needed as the second civil nuclear disaster in less than a quarter of a century clearly shows the deficiency of international standards on transparency. For example, while Japan declared an evacuation zone within $30 \mathrm{~km}$ of the plant, the United States recommended an evacuation distance of $80 \mathrm{~km} .{ }^{51}$ Some articles argued that this lack of nuclear transparency or cooperation could be traced back to states' design of the nuclear authority system; for example, as a result of geopolitical tensions during the Cold War, the World Health Organization (WHO) and the International Atomic Energy Agency (IAEA) were designed so that the WHO had no authority when it comes to health issues related to nuclear radiation. This article argued that this arrangement resulted in the concealment of facts and the denial of reality to protect the nuclear industry. It also criticized the industry's description of Fukushima's radiation levels as 'acceptable,' even though no one knew their actual level at the time. ${ }^{52}$ The IAEA had previously expressed interest in standardizing international cooperation in

\footnotetext{
${ }^{50}$ Didier Kechemair, "Quelles leçons tirer de l'accident de Fukushima?" LeMonde.fr, 25 March 2011, Eureka.cc.

${ }^{51}$ LeMonde.fr with Agence France-Presse (AFP) and Reuters, "Japon : des radiations "extrêmement fortes" à Fukushima," LeMonde.fr, 17 March 2011, Eureka.cc.

52 Jean-Luc Bennahmias, MEP; François de Rugy, MP (EELV); Guy Hascoět, former Secretary of State; Yannick Jadot MEP (EELV), "L'humanité a droit à la vérité sur le nucléaire," LeMonde.fr, 25 March 2011, Eureka.cc.
} 
nuclear accidents after the 1979 Three Mile Island incident and Chernobyl, and Fukushima was seen to reinforce this need. ${ }^{53}$

Both Le Figaro and Libération called for more international cooperation on nuclear issues. However, this was not always articulated in the same way. For example, one Le Figaro article called for international nuclear cooperation in order to reduce geopolitical tensions, with Iran and North Korea in mind. ${ }^{54}$ On the other hand, a Libération article saw the solution as giving the United Nations the power to intervene in nuclear disasters and establishing an international fund for this intervention. ${ }^{55}$

While both countries' media coverage references the democracy and transparency discussion, French coverage was far more active than German coverage. This could be related to Eurobarometer 271's finding that 84\% of French respondents felt uninformed about nuclear energy while only $68 \%$ of German respondents felt so. However, this paper would argue that this heightened French coverage actually reflects a reactivation of antinuclear framing that had been dormant in France since the anti-nuclear movement's demise in 1981. The French media also featured extensive coverage on the close relationship between the French government and the nuclear industry, which was not present to nearly the same degree in the German coverage. Most interesting however from these two parallel discussions is that the French media really seized upon the idea of international cooperation on nuclear energy. This could indicate a growing dissatisfaction

\footnotetext{
${ }^{53}$ Jean-Pierre Mignard, Raphael Romi, Sébastien Mabile, and Michel Mabile, "Le nucléaire est un bien public mondial," LeMonde.fr , 18 March 2011, Eureka.cc.

${ }^{34}$ Olivier Appert, "Pour un débat serein et global sur l'énergie," Le Figaro, 30 May 2011, Factiva; Sergei Kirienko, "La sûreté nucléaire est notre défi commun," Le Figaro, 26 May 2011, Factiva; Viktor Yanukovych, "Nucléaire : un seul monde, une seule sécurité," Le Figaro, 19 April 2011, Factiva. Factiva.

55 Galia Ackerman, "Fukushima : si on tirait des leçons de Tchernobyl ?" Libération, 25 April 2011,
} 
with the French government's handling of the nuclear industry and a feeling that nothing will change if nuclear safety is left in its hands.

\subsubsection{Focusing 'German Guilt' on Accountability}

In the German case, some journalists argued that Fukushima was really just the latest round in which the same arguments have been exchanged repeatedly after Three Mile Island, Chernobyl, and the 2000 nuclear phase-out pursued by the Social Democratic Party (SPD) and Greens. For example, Kister identifies a German 'guilt' arising out of its World War II history, but that this guilt did not prevent the previous worship of the state being replaced by an equally misguided blind faith in technology. In short, "Hegel retired, Siemens took over."

As in Le Monde, nuclear energy continued to be represented as a foil to democracy in Süddeutsche Zeitung as "democracy is too often understood as governance for the people, not a government by the people." ${ }^{57}$ During the period of study, 64 nuclear power plants were under construction around the world, with some commentators noting that construction is particularly present in countries with 'sham' democracies or dictatorships, particularly referring to Russia and China respectively. In these countries, the energy sector is a clear responsibility of the state, making public resistance unlikely. However, the article noted that in democratic countries where private investors bear the

\footnotetext{
${ }^{56}$ Kurt Kister, "Atomarer Glaubenskrieg," Süddeutsche Zeitung, 19 March 2011, Factiva. He refers to this guilt as encompassing a promise to never again stand idly by as citizens' ancestors had during the Nazi period.

37 "Außenansicht; Die Bürger als Zuschauer; Demokratie wird allzu oft als Regieren fur das Volk verstanden, nicht als Regieren durch das Volk," Süddeutsche Zeitung, 27 April 2011, Factiva.
} 
risks and costs of energy investment, only a few reactors are being built. ${ }^{58}$ Conversely, coverage in Die Welt framed the phase-out as more of an affront against democracy than the industry itself given its quick timelines that did not allow rational discussion or reflection. $^{59}$

In German newspapers, the transparency discussion was framed in terms of 'residual risk. ${ }^{60}$ Some articles criticized the default position that improved technology would prevent nuclear accidents as a reactor can never be completely safe; the IAEA recognized the reactor at Chernobyl as the safest reactor in the world merely a year before its explosion. ${ }^{61}$ In contrast to the ten years indicated in the French coverage, German risk assessments of nuclear technology had a statistical probability of a meltdown once every twenty-five years and, given the widespread impacts of an incident, many were becoming convinced that nuclear technology was a mistake. ${ }^{62}$ Further driving this idea of risk home, reports broke during the period of study that a security review in all 104 American nuclear power plants found issues in almost a third of the globally respected facilities. ${ }^{63} \mathrm{~A}$ Die Welt article echoed this point by stating that it is clear that nuclear energy is "a bet with very high stakes" and Fukushima allowed the discussion of

\footnotetext{
${ }^{58}$ Karl-Heinz Buschemann, "Kommentar; Atom ist totalitar; Kernkraft hat in Demokratien und Marktwirtschaften keine Zukunft," Süddeutsche Zeitung, 16 June 2011. Factiva.

${ }^{59}$ Thomas Schmid, "So wird die deutsche Demokratie ruiniert," Die Welt, 31 May 2011, Factiva.

${ }^{60}$ Steffen Hebestreit, "Angst vor der grunen Zukunft - Die FDP fuhrt in Stuttgart und Mainz Wahlkampf gegen einen neuen Gegner: Restrisiko und AKW-Laufzeiten," Berliner Zeitung, 22 March 2011, Factiva.

61 "Risikofaktor Mensch; Probleme der Atomnutzung sind auch durch bessere Technik nicht zu losen," Süddeutsche Zeitung, 13 May 2011, Factiva.

62 "Risikofaktor Mensch," 13 May 2011.

${ }^{63}$ "Măngel in US-Reaktoren," Süddeutsche Zeitung, 14 May 2011, Factiva.
} 
residual risk to come to the forefront, as nuclear proponents had traditionally dismissed this notion as a theoretical value. ${ }^{64}$ Transparency concerns were also present in Berliner Zeitung and Die Welt's coverage. For example, an article in Berliner Zeitung described the United Nations' condemnation of the Japanese government and TEPCO's lack of information sharing. ${ }^{65}$ In Die Welt, another article expressed concern that, in Germany, the federal government would not necessarily be involved in controlling a nuclear disaster as decision-making lies mostly with states. ${ }^{66}$ By this, the article likely meant that the administration of nuclear power plants lies with the states but, as previously mentioned, the federal government does have a great deal of control in setting the direction of nuclear policy.

Similarly to Le Monde, German newspaper coverage also contained discussions regarding who should pay for a nuclear accident and specifically whether the industry should be insured. In Germany, the nuclear operator is fully liable for a nuclear accident but the industry's total assets would likely not cover a fraction of the actual cost of a worst-case scenario. ${ }^{67}$ Therefore, the remainder (and majority) of the cost of a nuclear accident would be covered by taxpayers. This brings up another related point described in

\footnotetext{
${ }^{64}$ Norbert Lossau, "Nichts ist unmöglich," Die Welt, 8 April 2011, Factiva.

${ }^{65}$ Marc Engelhardt," UN verzweifeln an Japans Atomchaos - Chef der Umweltbehorde Steiner mahnt bessere Informationspolitik der Regierung an Merkel bietet deutsche Hilfe an / EU setzt Strahlengrenzwerte fur Lebensmittel herauf," Berliner Zeitung, 31 March 2011, Factiva.

${ }^{66}$ Katja Tichomirowa, "Jeder Kreis schutzt sich selbst - Der Bund hat im Fall eines Atomunfalls gar nichts zu melden. Die Lănder sind allein zustăndig," Berliner Zeitung, 2 April 2011, Factiva.

${ }^{67}$ Verena Wolff, "Atomkatastrophe in Japan: Die Kosten; Wer soll das alles zahlen?" Süddeutsche Zeitung Online, 16 March 2011, Factiva; Jakob Schlandt, "Kosten - "Die Konzerne mussen bezahlen" Atomausstieg - bis zum Jahr 2022 sollen alle Deutschen Kernkraftwerke vom Netz gehen. - 17 Kontaminierte Großanlagen mussen verschwinden. Es wird das Teuerste Abrissprogramm der Deutschen Geschichte," Berliner Zeitung, 14 June 2011, Factiva.
} 
the media coverage, namely that nuclear energy should be controlled by an independent authority as, according to opponents, in no other industry is the collusion of production and supervision interests as obvious as in nuclear energy. They argue that this integration is common worldwide, making the admission of safety issues problematic and leading to visible solidarity amongst power plant operators. ${ }^{68}$ This coverage strongly suggests a 'public accountability' package. While this package is not necessarily anti-nuclear, some coverage took it to this position.

Germany's government did not receive the same degree of accusations of being too close with the industry as the French government, which is likely due to the many institutional features that allow public monitoring and input. However, it did receive some of these accusations after its 2010 lifetime extension. One article noted that, throughout the German economy, few companies have gained the influence and control of the 'big four' in their respective industries. The market share of E.ON, RWE, Vattenfall and EnBW was 80 percent during the survey period, and these companies continued to prosper under the German government's lifetime extension in $2010 .{ }^{69}$ While there was a nuclear fuel tax to compensate for the lifetime extension, operators received on average 12 more years of profits in exchange. ${ }^{70}$

\footnotetext{
${ }^{68}$ Jeanne Rubner, "Außer Kontrolle; Die Verflechtung zwischen Behörden und Atomfirmen trägt zu der bedrohlichen Lage in Japan bei," Süddeutsche Zeitung, 29 March 2011, Factiva.

${ }^{69}$ Markus Balser, "Kommentare; Kurzschluss; Im Atomstreit manővrieren sich die Energiekonzerne ins Abseits," Süddeutsche Zeitung, 8 June 2011. Factiva.

${ }^{70}$ Guido Bohsem, "Schäuble kürzt den Wehretat; Die Regierung plant Haushalt mit Steuer auf AtomElemente. Die Neuverschuldung soll bis 2015 auf 13,3 Milliarden Euro sinken," Süddeutsche Zeitung, 15 March 2011. Factiva.
} 
The rapid shift from the coziness of German industry representatives and government officials in the 2010 lifetime extension to the quick decommissioning of the seven oldest reactors without notice in 2011 was noted by journalists. ${ }^{71}$ One article wryly commented that, while no side was completely pleased with the initial 14 June 2000 phase-out plan under the SPD-Greens, it was achieved through compromise; eleven years later, this relationship is far from amiable. While Germany has returned to almost its original phase-out plans, it now does so in conflict with nuclear operators. ${ }^{72}$ There is now a great deal of mistrust on both sides as operators accused Merkel of squandering this relationship for electoral gain, which jeopardizes the reliability of investment for the economy. Ironically, some business representatives expressed longing for a SPD-Green government as at least they knew where they stood. ${ }^{73}$

When Merkel announced the initial three-month shut-down of the seven oldest nuclear reactors on 14 March, the industry's tone was concerned but reassuring that companies were learning from the situation in Japan to improve safety measures. ${ }^{74}$ E.ON CEO Johannes Teyssen attempted to co-opt French government messaging by stating that the suffering in Japan should not be used for political debate and that excessive

\footnotetext{
${ }^{71}$ Markus Balser, "Falsch gepolt; Mit den Unfällen in Japan schwindet auch die Macht der einst gefurchteten deutschen Energiebosse. Dem Votum der Regierung haben sie nichts entgegenzusetzen," Süddeutsche Zeitung, 16 March 2011, Factiva.

${ }^{72}$ Michael Bauchmuller, "Kommentar; Rosenkrieg um Reaktoren; Die Regierung lăsst die Stromkonzerne fallen. Die Folgen reichen weit," Süddeutsche Zeitung, 14 June 2011, Factiva.

${ }^{73}$ Karl-Heinz Büschemann, "Kommentar; Raumschiff Berlin; Regierung und Wirtschaft misstrauen einander - das ist gefahrlich," Süddeutsche Zeitung, 31 May 2011, Factiva.

${ }^{74}$ Markus Balser, "Katastrophe in Japan: Politik und Wirtschaft debattieren uber die Zukunft deutscher Kernkraftwerke; „Stilllegen ist mogglich“; Atom-Lobbyist Ralf Guldner uber Sorgen der Branche,” Süddeutsche Zeitung, 15 March 2011, Factiva.
} 
government regulation prevents progress. ${ }^{75}$ However, German companies generally did not widely comment on the government's decision prior to the March state elections. ${ }^{76}$ This could be due to the fact that Minister Rainer Brüderle (FDP) essentially told nuclear industry representatives during an industry association meeting that the new shift in nuclear policy should not be taken seriously and was taken in response to the upcoming elections. ${ }^{77}$ However, Teyssen again tried to shift the discourse back to Germany's energy security in an interview published on 22 March through discussing the heightened risk of power outages and cautioning that the network was not prepared for these drastic changes. ${ }^{78}$ Yet, as one article noted, it has been proven that nuclear energy is dispensable in Germany, as it has long made do with other sources when plants needed to be taken off the grid for one reason or another. ${ }^{79}$ During this time, the SPD and Greens were questioning the impartiality of the government's nuclear experts and called for the resignation of the top German nuclear overseer, Gerald Henn Höfer. Appointed to head the Department of Nuclear Safety, Höfer had previously worked as a lobbyist for E.ON to

\footnotetext{
${ }^{75}$ Matthias Vogel, "Unter Stromverbrauchern; Eon-Vorstand Johannes Teyssen referiert beim Empfang der Kreishandwerker uber seine Sicht der Energiepolitik," Süddeutsche Zeitung, 14 March 2011, Factiva.

${ }^{76}$ LeMonde.fr with Agence France-Presse (AFP), "Les géants de l'énergie allemande contre le moratoire sur le nucléaire," LeMonde.fr , 2 April 2011, Eureka.cc.

${ }^{77}$ Lena Jakat and Oliver Das Gupta, "Briderle, das Moratorium und der Wahlkampf; Regierung geht in Deckung, Opposition frohlockt," Süddeutsche Zeitung Online, 24 March 2011, Factiva; Heribert Prantl, "Klingeling, hier kommt die Kanzlerin; Glaubwurdigkeits-Katastrophe: Warum der CDU-Wahlkampf an die alemannische Fastnacht erinnert," Süddeutsche Zeitung, 25 March 2011, Factiva.

${ }^{78}$ LeMonde.fr with Agence France-Presse (AFP), "Allemagne : EON souligne le risque d'un blackout," LeMonde.fr, 22 March 2011, Eureka.cc.

${ }^{79}$ Markus Balser,"Es geht doch; Konzerne erwarten keinen Engpass bei Stromversorgung," Süddeutsche Zeitung, 16 March 2011, Factiva; Martin Kotynek, " Eingebaute Măngel; Die Technik der AltMeiler ist uberholt und fehleranfallig," Süddeutsche Zeitung, 16 March 2011, Factiva.
} 
negotiate on behalf of corporations during the previous nuclear phase-out with the SPDGreens. $^{80}$

After getting a sense of public opinion through the election results, Germany's industry began to strike back against the suspension. While E.ON CEO Teyssen mounted a public relations strategy by stressing that a nuclear exit that met climate targets by 2025 was unrealistic, RWE announced they were lodging a complaint against the decision. ${ }^{81}$ It was also reported that, as of 26 May, the German government was prepared to waive a nuclear fuel tax in exchange for operators' support of a rapid phase-out. Created in exchange for the 2010 lifetime extension, the tax would have brought more than $€ 2$ billion per year in taxes. Given the suspension of this extension after Fukushima, E.ON and RWE argued against the tax and threatened legal action. ${ }^{82}$

Yet this compromise did not come to pass. On 6 June, the German government adopted a bill to phase out of nuclear energy by $2022 .^{83}$ Operators complained that they were not involved in the negotiations and only knew what was reported in the media. Through the phase-out and the continuation of the fuel tax, it was a defeat for the energy

\footnotetext{
${ }^{80}$ Michael Bauchmuller, "Zweifel an Atomaufsicht; Umweltschutzer und Grune fordern unabhängige Prufung," Süddeutsche Zeitung, 22 March 2011, Factiva.

${ }^{81}$ Markus Balser, "Ausstieg aus dem Kuschelkurs; Eon-Chef Johannes Teyssen geht in der Atomdebatte auf Konfrontationskurs zu Bundeskanzlerin Angela Merkel," Süddeutsche Zeitung, 6 May 2011. Factiva; LeMonde.fr with Agence France-Presse (AFP), "L'allemand RWE porte plainte contre l'arrêt d'un de ses réacteurs par Berlin," LeMonde.fr, 1 April 2011, Eureka.cc.

${ }^{82}$ LeMonde.fr with Agence France-Presse (AFP), "Berlin prêt à abandonner une taxe sur le combustible nucléaire," LeMonde.fr, 27 May 2011, Eureka.cc.

${ }^{83}$ LeMonde.fr with Agence France-Presse (AFP), "Berlin adopte le projet de loi d'abandon du nucléaire," LeMonde.fr , 7 June 2011, Eureka.cc.
} 
industry across the board. ${ }^{84}$ Vattenfall CEO Øystein Løseth and RWE CEO Juergen Grossmann wrote a letter of protest to Merkel and insisted that the 2010 promise of a lifetime extension be honoured. Løseth said Vattenfall expected fair compensation for the decommissioning of nuclear reactors in Krümmel and Brunsbüttel as they invested over $€ 700$ million under the understanding that they could continue to operate. ${ }^{85}$ For EnBW, the moratorium was estimated to cost $€ 800$ million. ${ }^{86}$ E.ON needed to shut down two reactors permanently, while already having lost $€ 250$ million during the moratorium and it was likely lose a billion euros per year through the loss of these reactors. It later announced it would be pursuing legal action. ${ }^{87}$ Its competitor RWE also announced that it was considering legal action against the government, while industry association BDI warned that achieving climate goals without nuclear energy would be difficult and expensive. $^{88}$

In summary, while there was a discussion surrounding democracy, transparency, and risk in Germany, it was nowhere as predominant as the comparable discussion happening in France. This could be due to a variety of factors, but is most likely due to the fact that, in Germany, the public could enact change as demonstrated in first the

\footnotetext{
${ }^{84}$ Markus Balser, "Chef-Etage abgeschaltet; Die Energiebranche furchtet nach dem Ende fur die Kernkraft in Deutschland Milliarden-Ausfalle. Der Streit mit der Politik eskaliert," Süddeutsche Zeitung, 31 May 2011, Factiva.

${ }^{85}$ Markus Balser, Michael Klăsgen and Gunnar Herrmann, "Angst um die Rendite; Die Atomkonzerne beklagen sich bei der Bundesregierung," Süddeutsche Zeitung, 8 June 2011, Factiva; Daniel Wetzel, "AKW-Betreiber wehren sich," Die Welt, 8 June 2011, Factiva.

86 "Atomkonzern EnBW will grün warden," Die Welt, 20 April 2011, Factiva.

${ }^{87}$ Markus Sievers and Jakob Schlandt, "Eon klagt gegen Brennelemente-Steuer - Länder fordern Änderungen am Atom-Kompromiss," Berliner Zeitung, 1 June 2011, Factiva.

${ }^{88}$ Balser, "Chef-Etage abgeschaltet," 31 May 2011.
} 
three-month moratorium and later in the nuclear phase-out. This quantity of discussion was also likely muted by the chilling of the relationship between nuclear operators and the government since the lifetime extension in 2010. Interestingly, media calls for international regulation or even cooperation are not present to the same degree in Germany as in France, which could indicate that the Germans are satisfied with the degree to which they can influence their national approach to nuclear energy.

\subsubsection{Government-Public and State-Industry Relationships Concerning Nuclear}

\section{Energy}

While the public might have been concerned about the particularly close relationship between their government and the domestic nuclear industry, there are good reasons for why the government is closely involved. The dualism of nuclear energy necessitates heavy state involvement. The Non-Proliferation Treaty allows all signatories to develop nuclear energy for civilian use and from there only small technological adjustments are needed to transform this civilian capacity into weaponry ${ }^{89}$ Thus, nuclear dualism means that the state must always have some regulatory control over nuclear energy as it has a monopoly on the use of force within its borders. However, there is no question that concerns about democracy and transparency are significantly represented in both newspapers' coverage on the nuclear debate, particularly in the French coverage.

Public concerns about the democracy or transparency of the nuclear industry have been present in both France and Germany for the past fifty years and formed much of the anti-nuclear movement's narrative. These concerns have been most often expressed in a

\footnotetext{
${ }^{89}$ Joschka Fischer, "Außenansicht; Geliebte Bombe; Warum die Atomwaffenmächte auch nach Fukushima keinen Ausstieg aus der Nuklearenergie wollen," Süddeutsche Zeitung, 10 May 2011, Factiva.
} 
'public accountability' package but, during the response to the Fukushima crisis, a parallel package emerged that may be described as 'real risk' or 'residual risk.' This package demanded that a full and transparent risk assessment be conducted and shared with the public. Both of these packages prompted the creation of an anti-nuclear framing in France after the Fukushima crisis, and amplified the German public's responsiveness to already existing anti-nuclear framing.

Ironically, given the relative non-existence of public mobilization, French coverage was far more active than German coverage when concerning discussions of democracy and transparency as well as the close relationship between government and industry. As mentioned in the previous section, this could be related to Eurobarometer 271 's finding that $84 \%$ of French respondents felt uninformed about nuclear energy while only $68 \%$ of German respondents felt so. However, this could also be related to the fact that only $50 \%$ of French respondents felt that their national legislation was sufficient for nuclear safety ${ }^{90}$ This paper argues that there must be a clear framing of the issue as well as a political opportunity for this framing to manifest itself in a policy change. However, this framing must be in place prior to the political opportunity and this clearly was not present in the French case. However, if one refers back to Snow and Benford's three core framing tasks discussed in the literature review - diagnostic framing, prognostic framing, and motivational framing - it becomes evident that the comparatively higher discussion in France around the transparency and democracy aspects of nuclear policy is part of the first two core framing tasks. In other words, this French discussion was part of efforts to

\footnotetext{
${ }^{90}$ Special Eurobarometer 271: Europeans and Nuclear Safety. Published February 2007, October November 2006. Retrieved from http://ec.europa.eu/public opinion /archives/ebs/ebs 271 en.pdf on 12 February 2013, 27.
} 
define a shared understanding of the problem and who is responsible as well as agreeing on a solution to this problem, which in this case seemed to be international cooperation and regulation of the global nuclear industry. This paper also hypothesizes that historical experience as manifest in political institutions play a mitigating role in encouraging or discouraging political change. Clearly, the centralized French political system is far more resistant to public input when not in an election period compared to the German system. This could be another reason for this heightened discussion in France; there were simply no other methods for providing input on nuclear policy. For these reasons, while an antinuclear framing was not present to mobilize itself to take advantage of the Fukushima political opportunity, the Fukushima disaster clearly prompted heightened French media coverage that reflected the beginning of a new anti-nuclear framing process that seemed to define transparency and democracy concerns as well as government collusion with the nuclear industry as 'the problem' while proposing extensive international cooperation as 'the solution.'

In Germany on the other hand, an anti-nuclear framing has been in place since the 1970s but it did not have the significant Fukushima or 'super' election year political opportunities to manifest itself in a definitive nuclear policy change. Therefore, while there was a discussion surrounding democracy, transparency, and risk in Germany, it was nowhere as predominant as the discussion happening in France simply because the German public already had a shared understanding of the problems posed by nuclear energy. As in the past, the 'soft steps' and 'public accountability' packages were popular in Germany with the relatively new addition of the 'real risk' or 'residual risk' package. Thus, if one accepts that this framing was already in place, this lends support to this 
paper's argument that there must a framing in place to take advantage of an available political opportunity. Institutional factors are likely also important in explaining the discrepancy between French and German media coverage; in the comparatively more 'open' German political system, the public could enact change as demonstrated in first the three-month moratorium and later in the nuclear phase-out.

In summary, the French and German media's coverage of concerns about the transparency and democracy aspects of nuclear energy as well as the relationship between government and industry provides a glimpse of how each public understood the nuclear energy issue. In France, a lack of anti-nuclear framing since 1981 prompted heightened discussion on the nuclear issue and seemed to diagnose any problems as resulting from the closed-off nature of the nuclear industry. In Germany, the public already appeared to have a shared understanding of the problems of nuclear energy so while this discussion was present, more media coverage was diverted to exploring how the previously existing anti-nuclear frames were manifesting themselves in policy change. With this understanding of how each public was discussing the issue, this paper will now turn to two case studies that focus exclusively on each government's reaction, starting with the French government.

\subsection{French Frames: Energy Independence, Progress, and Cheap Electricity}

The French government's (led by the Union pour un mouvement populaire or UMP) reaction to the Fukushima crisis can be summarized as dismissive of those who wanted to reopen the nuclear debate in France, initially as 'indecent' of the suffering of the Japanese and later as 'irrational.' The political slur 'indecent' was used to accuse the opposition of trying to capitalize on the suffering of the Japanese people to reopen the 
nuclear debate in France and would continue to be referenced throughout the period of study. The government continued to support nuclear energy throughout this paper's study and tried to promote this support through the 'energy independence' and updated 'progress' packages, along with publicizing nuclear energy as the reason for 'cheap electricity' in France, which became a uniquely French package. However, the French public and media increasingly challenged these packages.

Controversially, the Minister of Industry and Energy, Éric Besson, initially tried to assure the French public that the Fukushima disaster was a serious accident but not a nuclear disaster and that it was nowhere near the level of Chernobyl. ${ }^{91}$ In contrast to the soothing picture provided by French authorities, American experts' assessments of the Fukushima incident likened it directly to Chernobyl as the presence of cesium in the atmosphere after the Daiichi plant released surplus steam indicated that partial melting is underway. ${ }^{92}$ One of Le Monde's articles tried to differentiate the situation in France versus Japan by focusing on the characteristics of Fukushima reactor no. 1, in which it was explained that Fukushima's nuclear reactors are boiling water reactors in contrast to France's pressurized water reactors. ${ }^{93}$ Japanese authorities initially assessed the incident as a Level 4 on the International Nuclear Event Scale (INES), which describes accidents

\footnotetext{
91 "Accident nucléaire au Japon : les autorités françaises se veulent rassurantes," LeMonde.fr, 13 March, Eureka.cc.

92 "Des experts américains redoutent un Tchernobyl au Japon," LeMonde.fr, 13 March, Eureka.cc.

${ }^{93}$ Hervé Morin, "Menace nucléaire au Japon : Les caractéristiques du réacteur de Fukushima no 1," Le Monde, 14 March 2011, Eureka.cc; LeMonde.fr with Agence France-Presse (AFP) and Reuters, "En direct : nouvelle explosion a l'usine de Fukushima," LeMonde.fr, 14 March 2011, Eureka.cc.
} 
that do not result in significant off-site risk. ${ }^{94}$ Interestingly, while the Japanese authorities placed Fukushima as 4 out of 7 on the INES scale, the French Nuclear Safety Authority (ASN) assessed its initial severity as a 5, which is beyond Three Mile Island but not near the 7 of Chernobyl. ${ }^{95}$ The ASN would soon reclassify the incident as a $6 .{ }^{96}$ Along with attacking the opposition as 'indecent,' the government continued to emphasize that French nuclear technology was the safest in the world. ${ }^{97}$

In response to the government's accusations, opposition parties criticized Sarkozy's accusations of 'indecency' because he had previously angled to sell nuclear energy to Libyan dictator Muammar Gaddafi. ${ }^{98}$ One article suggested that, as France had no discourse about nuclear risk, the real-time unfolding of the Fukushima crisis was causing anxiety and causing the French to question their system, even though there was no domestic accident. ${ }^{99}$ Fukushima did prompt some revival of anti-nuclear protest in

\footnotetext{
94 "Japon : plus de 1800 morts et disparus, un accident nucléaire majeur," LeMonde.fr, 13 March, Eureka.cc; LeMonde.fr with Agence France-Presse (AFP), "Angoisse pour une deuxième centrale nucléaire au Japon," LeMonde.fr, 13 March 2011, Eureka.cc.

95 "Japon : une catastrophe nucléaire menace, le bilan humain reste incertain," LeMonde.fr, 15 March 2011, Eureka.cc.

${ }^{96}$ LeMonde.fr with Agence France-Presse (AFP) and Reuters, "Japon : désolation à Fukushima, inquiétude à Tokyo," LeMonde.fr, 16 March 2011, Eureka.cc; "L'ASN classe l'accident nucléaire de Fukushima au niveau 6," LeMonde.fr, 16 March 2011, Eureka.cc.

${ }^{97}$ Michael Klăsgen, "Streitende Franzosen; Die Regierung in Paris verteidigt die Atomkraft," Süddeutsche Zeitung, 15 March 2011, Factiva.

${ }^{98}$ Chat with Noel Mamère moderated by Eric Nunès, "Sarkozy "un VRP d'Areva qui voulait vendre une centrale nucléaire à Kadhafi"," LeMonde.fr, 17 March 2011, Eureka.cc.

${ }^{99}$ Interview with Christian Navarre by Marion Solletty, "Devant la catastrophe au Japon, "un stress collectif mondial"," LeMonde.fr, 17 March 2011, Eureka.cc.
} 
France and speculation on whether Fukushima was another Chernobyl ran rife. ${ }^{100}$ Approximately 300 people gathered in front of the Eiffel Tower to show solidarity with Japan and protest nuclear energy. ${ }^{101}$ In another example, 10,000 demonstrators gathered from sixty national organizations near Fessenheim on 20 March to call for a phase-out of nuclear energy while hundreds of other protesters demonstrated in Paris, Colmar and Nantes. ${ }^{102}$ However, this is the exception rather than the rule; France continued to count protesters in the hundreds while in Germany they were counted by the thousands.

The French government ultimately needed to adjust the tone of its message given the public backlash, though this backlash was mostly led by the Parti socialiste (PS) and EELV. Energy Minister Besson shifted his assessment of the situation to acknowledge that one could not exclude the possibility of a nuclear disaster and nuclear debate is legitimate - striking a far less controversial tone. ${ }^{103}$ In the afternoon of 16 March, Sarkozy chaired a ministerial meeting on the Fukushima nuclear accident, with François Fillon, Christine Lagarde, Nathalie Kosciusko-Morizet and Éric Besson. ${ }^{104}$ Prime Minister Fillon subsequently ordered inspections of all 58 nuclear reactors with results to

\footnotetext{
${ }^{100}$ Arnaud Leparmentier, "La crise nucléaire japonaise relance le débat sur l'atome en France," Le Monde, 15 March 2011, Eureka.cc; Chat with Pierre Le Hir moderated by François Béguin, "Fukushima est-il un nouveau Tchernobyl ?" Le Monde, 17 March 2011, Eureka.cc.

${ }^{101}$ LeMonde.fr with Agence France-Presse (AFP), "Les anti-nucléaires donnent de la voix après l'accident de Fukushima," LeMonde.fr, 14 March 2011, Eureka.cc.

102 "Sur mesure," LeMonde.fr, 21 March 2011, Eureka.cc.

${ }^{103}$ Alexandre Piquard, "Japon : comment le discours du gouvernement français a évolué," LeMonde.fr, 15 March 2011, Eureka.cc.

${ }^{104}$ LeMonde.fr with Agence France-Presse (AFP), "'Les heures qui viennent seront essentielles"," LeMonde.fr, 17 March 2011, Eureka.cc.
} 
be ready by the end of $2011 .{ }^{105}$ President Sarkozy further promised that any reactors that failed these safety assessments would be closed. ${ }^{106}$ The Minister for Ecology, Nathalie Kosciusko-Morizet, dismissed a referendum on nuclear energy as inappropriate as it would be manipulated for political purposes given the fact that it was a year before the presidential elections. ${ }^{107}$ She also rejected the usefulness of debate at that time as nuclear energy would continue to be an issue in 2012 and could thus be dealt with during the election debates. ${ }^{108}$ However, Sarkozy left no question that France was sticking with its nuclear course. ${ }^{109} \mathrm{He}$ did however try to assure the public that he was staying apprised "by the minute" of the situation and was taking steps to ensure such an incident could not occur in France. Sarkozy said he was open to 'listening' to other parties, but nuclear energy was an essential element of France's energy independence and the fight against greenhouse gas emissions. ${ }^{110}$ Echoing its presence in the French media framing discussed in the previous section, Sarkozy called for international standards for nuclear safety on

\footnotetext{
105 "Audit public des réacteurs français François Fillon a ordonné hier l'inspection des 58 réacteurs nucléaires français par l'Autorité de sûreté nucléaire," LeMonde.fr , 25 March 2011, Eureka.cc; Bennahmias, de Rugy, Hascoêt, and Jadot. "L'humanité a droit à la vérite," 25 March 2011.

${ }^{106}$ LeMonde.fr with Agence France-Presse (AFP) and Reuters, "Sarkozy promet de fermer les centrales nucléaires qui échoueraient aux tests," LeMonde.fr, 26 March 2011, Eureka.cc.

${ }^{107}$ LeMonde.fr with Agence France-Presse (AFP), "NKM pourrait ne pas prolonger la durée de vie des centrales nucléaires françaises," LeMonde.fr, 20 March 2011, Eureka.cc.

${ }^{108}$ LeMonde.fr with Agence France-Presse (AFP), "Le rapport Roussely préconise un groupement d'intérêt économique des grands acteurs du nucléaire français," LeMonde.fr, 22 March 2011, Eureka.cc.

109 "Sarkozy : la France restera nucléaire Le chef de l'Etat a dit hier qu'il n'était "évidemment pas question de sortir du nucléaire" pour la France, qui a le parc " le plus sécurisé" et le plus important de l'UE, avec," LeMonde.fr, 15 March 2011, Eureka.cc. Eureka.cc.

110 "Sarkozy convaincu de la "pertinence" du nucléaire pour la France," LeMonde.fr, 17 March 2011,
} 
his visit to Japan on 31 March. While expressing his solidarity with Japanese authorities, he also called for the G20 to discuss nuclear safety at their upcoming meeting. ${ }^{11}$

The government's response embodied the traditional 'energy independence' package as well as the newer 'low carbon alternative' package that this paper proposed in the literature review. Government officials also began to expand the 'progress' package with a special French variant, namely that French technology was more technologically advanced and safer than any other in the world. According to Besson, French citizens should be reassured that all French power plants were designed with seismic and flooding safety features. ${ }^{112}$ ASN President, Andre-Claude Lacoste, maintained that thousands of inspections were done every year on the French reactors and that everyone needed to wait to assess possible lessons from the Fukushima incident. ${ }^{113}$ The mark of a strong package is when it can be adapted to explain new events and trends; for example, the 'progress' package was expanded after Chernobyl as "American nuclear reactors cannot be compared with their Soviet counterparts any more than their political systems are comparable." $" 14$ In other words, American technology was viewed to be far superior to Soviet technology. The expansion of the 'progress' narrative in this case was a little more problematic as Japan is a technologically-advanced, democratic state, but as a exporter of

\footnotetext{
111 LeMonde.fr with Agence France-Presse (AFP) and Reuters, "Sarkozy en visite à Tokyo pour exprimer sa "solidarité"," LeMonde.fr, 31 March 2011, Eureka.cc; Régis Arnaud, "Au Japon, l'image de la France se rétablit," Le Figaro, 4 April 2011, Factiva; Charles Jaigu, "A Tokyo, Sarkozy réaffirme son choix du nucléaire," Le Figaro, 1 April 2011, Factiva; Antoine Bouthier, "La crise nucléaire, une épreuve difficile pour la diplomatie française au Japon," LeMonde.fr, 2 April 2011, Eureka.cc.

112 "Accident nucléaire au Japon," 13 March 2011.

113 Ibid., 13 March.

${ }^{114}$ William A. Gamson and Andre Modigliani. "Media Discourse and Public Opinion on Nuclear Power: A Constructionist Approach," American Journal of Sociology, Vol. 95, No. 1 (Jul., 1989), 21.
} 
nuclear technology, France used this opportunity to promote its Areva's new safer EPR reactor and itself as the leader in safe nuclear technology. Contrary to France's claims of technological superiority however, Japan refused France's offer of specialized intervention robots, which can remotely operate in a hostile environment. ${ }^{115}$ Ironically, Japan accepted comparable robots from the United States a little later. ${ }^{116}$ In addition, ASN reported on 19 May that Areva's nuclear waste processing plant in BeaumontHague underestimated the severity of several incidents in $2010 .{ }^{117}$ This called not only French nuclear safety into question, but also the transparency by which safety issues were shared with the public, perhaps further encouraging the growth of anti-nuclear framing as discussed in the previous section.

In response to the government's packages, nuclear opponents began to provide counter-packages. While France did not have a ready anti-nuclear frame in place to take advantage of Fukushima, the framing process had begun anew after Fukushima as discussed in the previous section and this increased the opposition's confidence to challenge the government's pro-nuclear packages. During the first half of the survey period, the government's primary packages were 'energy independence' and 'low carbon alternative.' Seemingly in response to the German shift towards a nuclear phase-out, a 'cheap electricity' package became increasingly used as government officials emphasized the extent to which German energy prices would now rise. As many opponents point out,

\footnotetext{
${ }^{115}$ “Quel rôle pour Areva dans le sauvetage de Fukushima ?" LeMonde.fr, 30 March 2011, Eureka.cc.

${ }^{116}$ LeMonde.fr with Agence France-Presse (AFP), "Crise nucléaire au Japon : Obama réitère son soutien et compte envoyer des robots," LeMonde.fr, 30 March 2011, Eureka.cc.

${ }^{117}$ LeMonde.fr with Agence France-Presse (AFP), "L'usine Areva de la Hague a sous-déclaré plusieurs de ses incidents," LeMonde.fr , 20 May 2011, Eureka.cc.
} 
the idea of French energy independence was somewhat of an illusion. While it certainly did provide some relief during the oil crises, France imported its uranium just as it did its oil and gas. ${ }^{118}$ Opponents also argued that the energy independence argument needs to be placed in context; France was $75 \%$ dependent on fossil fuels largely through its oil imports so, while nuclear energy generated $80 \%$ of domestic electricity production, nuclear energy alone did not give France energy independence. ${ }^{119} \mathrm{~A}$ lesser-used counterpoint was that nuclear energy actually generates pollution at all stages of its operations. For example, uranium mining uses more than 600 tons of ore to obtain one usable ton - as François argues, the $\mathrm{CO} 2$ emissions are not insignificant. ${ }^{120}$ Finally, contrary to the government's 'cheap electricity' package, nuclear energy is quite costly in terms of plant decommissioning, construction, and waste management for centuries. ${ }^{121}$ Furthermore, news broke that the government (through EDF) was considering annual increases in electricity prices between $5.1 \%$ and $6.5 \%$ by 2015 (including inflation) or approximately $30 \%$ in five years, which was a clear departure from its previous policy of $1 \%$ and $3 \%$ since $2007 .{ }^{122}$ EDF quickly denied this dramatic increase, but Energy Minister Besson had previously confirmed that an increase in electricity prices was inevitable in order to finance nuclear and renewable energy development. ${ }^{123}$ There was

\footnotetext{
118 Lhomme, "Crise nucléaire," 15 March 2011; "Papier de verre," LeMonde.fr, 17 March 2011, Eureka.cc.

${ }^{119}$ Huchon, "Pour sortir du nucléaire," 6 April 2011.

${ }^{120}$ François, "Il faut sortir de la religion de l'atome," 18 March 2011.

${ }^{121}$ Ibid., 18 March 2011.

${ }^{122}$ LeMonde.fr with Agence France-Presse (AFP), "Prix de l'électricité : EDF voudrait des hausses de plus de $5 \%$ par an sur cinq ans," LeMonde.fr, 23 March 2011, Eureka.cc.

${ }^{123}$ LeMonde.fr with Agence France-Presse (AFP), "Prix de l'électricité," 23 March 2011.
} 
also the fact that France's nuclear power plants were aging and its power distribution network needed to be updated. While the French continued to have one of the lowest electricity bills in Europe, their bill increased by $3 \%$ on 15 August 2010 and again on 1 January 2011. ${ }^{124}$ Furthermore, new prices increases had already been announced for renewable energy development as per Besson's statement. ${ }^{125}$

Minister Besson reiterated that the government's two main concerns were the competitiveness of its nuclear industry and the public's purchasing power. ${ }^{126}$ On 5 April, the government froze the price of electricity for a year (suspiciously until the 2012 presidential elections were over). ${ }^{127}$ This price freeze was a response to growing public skepticism on nuclear energy, and rumours that price increases were forthcoming. As part of the state's narrative on nuclear energy was that it allowed cheap energy prices, it was essential that this narrative be reinforced. The media coverage also reviewed some surveys that showed a growing concern about the dominance of nuclear energy in France. While there was obviously little protest in the streets, public skepticism was growing. For EDF, their desired lifetime plant extensions would be jeopardized if tightening safety standards made maintenance so expensive that extensions were no longer viable.

\footnotetext{
${ }^{124}$ LeMonde.fr with Agence France-Presse (AFP), "Prix de l'électricité," 23 March 2011.

${ }^{125}$ Ibid., 23 March 2011.

${ }^{126}$ LeMonde.fr with Agence France-Presse (AFP), "Prix de l'électricité,"23 March 2011. Factiva.

${ }^{127}$ Frédéric De Monicault, "Prix de l'énergie : l'État décrète une pause," Le Figaro, 6 April 2011,
} 
However, Areva and EDF still hoped to be able to convert Fukushima anxiety into an argument for the seemingly safer, though expensive, EPR pressurized water reactor. ${ }^{128}$

The government suffered another blow to its narrative control when more polls suggested that the French public were increasingly uncertain about nuclear energy; an April survey commissioned by the magazine $L$ 'Express and conducted by the OpinionWay firm suggested that a majority of French citizens (57\%) supported a withdrawal from nuclear energy. ${ }^{129}$ However, this finding is complicated by the fact that only $27 \%$ were prepared to accept increased energy prices as opposed to $72 \%$ who refused to do so. ${ }^{130}$ This is a finding to which the government likely clung, but it ignores the fact that the price has little to do with nuclear energy as, according to opponents, it is rather a result of government policy to subsidize its production. The majority of the 30 representatives of the French and German energy industry agreed on this subsidy assessment in a meeting with the German ambassador in Paris; one journalist wryly noted that France decided on a price freeze the day before this meeting. ${ }^{131}$

Perhaps in response to growing public skepticism, EDF's CEO, Henri Proglio, pronounced the state of the 58 French reactors to be 'excellent' on 18 April. Proglio also rejected calls that Fessenheim should be closed despite its age, arguing that it has been

\footnotetext{
${ }^{128}$ Michael Kläsgen, "In Frankreich wächst der Zweifel," Süddeutsche Zeitung, 7 April 2011, Factiva.

${ }^{129}$ Klăsgen, "Zweifelnde Franzosen," 16 April 2011.

${ }^{130}$ Reuters, "Majority of French want to drop nuclear energy-poll," Reuters, 13 April 2011. Retrieved from http://www,reuters.com/article/2011/04/13/france-nuclear-poll-idAFLDE73C0Z120110413 on 24 January 2013.

${ }^{131}$ Klăsgen, "Zweifelnde Franzosen," 16 April 2011.
} 
updated continuously. ${ }^{132}$ He acknowledged that Fukushima may delay many nuclear projects but that EDF will learn from the accident and it will not affect nuclear energy in France. He also said that France would aim for its 2020 energy mix to be $50 \%$ nuclear, $25 \%$ in the thermal (gas, charon) and $25 \%$ in hydro and other renewables. ${ }^{133}$ The German direction towards a nuclear phase-out started to become increasingly clear at this time, causing Sarkozy to condemn those, like Merkel, who rashly took decisions on the future of nuclear power. ${ }^{134} \mathrm{He}$ issued similar calls for composure and calm so that France could rationally consider the problem in response to a PS campaign platform, which was critical of nuclear energy. ${ }^{135}$

Another Le Monde article speculated on Sarkozy's environmental strategy for his 2012 re-election campaign. In approaching the following year's presidential elections, Sarkozy wanted to find a unifying issue and Lawrence suggested that he decided to differentiate himself as unabashedly pro-nuclear. ${ }^{136}$ Sarkozy clearly tried to accomplish this by adopting a 'progress' package to dismiss environmentalists' attempts to "return to the candle" through the abandonment of the technologically advanced nuclear

\footnotetext{
${ }^{132}$ LeMonde.fr with Agence France-Presse (AFP), "Pour le président d'EDF, les centrales nucléaires françaises sont en bon état," LeMonde.fr, 18 April 2011, Eureka.cc.

${ }^{133}$ Jean-Michel Bezat, "Fukushima "ne remet pas en cause le nucléaire", selon le patron d'EDF," LeMonde.fr, 25 May 2011, Eureka.cc.

${ }^{134}$ LeMonde.fr with Agence France-Presse (AFP) and Reuters, "A Tokyo, Sarkozy plaide pour des normes internationales de sécurité nucléaire," LeMonde.fr, 1 April 2011, Eureka.cc.

${ }^{135}$ LeMonde.fr with Agence France-Presse (AFP) and Reuters, "Nucléaire, pouvoir d'achat... Sarkozy critique le programme du PS," LeMonde.fr, 8 April 2011, Eureka.cc.

${ }^{136}$ Samuel Lawrence, "L'environnement, nouvelle étape de l'opération réconciliation de Nicolas Sarkozy," LeMonde.fr, 23 April 2011, Eureka.cc.
} 
technology. ${ }^{137}$ Sarkozy reiterated that to abandon nuclear energy would be for France to "cut off an arm." 138 These 'medieval' descriptions clearly reflect a 'progress' package. He further tried to underscore that Fukushima was a result of a natural disaster, and "a tsunami in the center of France would be a novelty." on 2 May that France would not abandon nuclear energy, but he did agree to an NGO proposal to have the Court of Auditors perform an audit of the "actual cost" of the industry, possibly to defuse speculation that nuclear energy was in fact not as affordable as the government portrayed it to be. ${ }^{140}$

In response to the German nuclear exit announcement on 30 May, Sarkozy remained committed to strengthening the French nuclear industry. ${ }^{141}$ Sarkozy further noted that he saw the German exit as a good opportunity for French energy exports. While he did not directly repeat his previous accusation of Germany being overemotional, he reiterated that he was not elected to destroy an industry that creates jobs and provides energy security to France while continuing to indirectly blame

\footnotetext{
${ }^{137}$ Samuel Lawrence, "L'environnement, nouvelle étape de l'opération réconciliation de Nicolas Sarkozy," LeMonde.fr, 23 April 2011, Eureka.cc. Eureka.cc.

138 "Sarkozy : sortir du nucléaire reviendrait à "se couper un bras"," LeMonde.fr, 23 April 2011,

139 "Sarkozy : sortir du nucléaire reviendrait à "se couper un bras"," 23 April 2011.

${ }^{140}$ LeMonde.fr with Agence France-Presse (AFP) and Reuters, "Sarkozy accepte un audit sur le "cout réel" du nucléaire en France," LeMonde.fr, 3 May 2011, Eureka.cc.

141 "25 Stunden fur die Rettung der Welt; Die Großen Acht haben so viele Themen auf dem Konferenztisch, dass manchem davon schon vorher ganz schwindelig ist," Süddeutsche Zeitung, 26 May 2011, Factiva.
} 
emotions, lack of composure, and the media debate for Germany's unexpected decisions. $^{142}$

Besson also echoed Sarkozy's sentiment, stating that France was not alone in its continued commitment to nuclear policy as the United States, China, India, Britain, the Czech Republic, Bulgaria, and even Japan were continuing with their nuclear plans. Besson added that the price of electricity would increase for German businesses and consumers. ${ }^{143}$ Areva's CEO, Anne Lauvergeon, also pointed out that Germany reacted differently from the rest of Europe and she questioned Germany's logic, as they would have to import nuclear energy from other countries. ${ }^{144}$

This narrative was established primarily from Le Monde's coverage and will now be validated through a brief comparison with Le Figaro and Libération's coverage. Le Figaro and Libération had comparable coverage to Le Monde on most dates of interest as well as in the description of the French government's approach. However, both did differ in some ways. Le Figaro had more coverage describing why France needed to continue with its nuclear course. For example, one article argued that the causes of Fukushima were not mysterious or complex and that safety solutions could be found quickly. ${ }^{145} \mathrm{Le}$ Figaro was also more likely to feature coverage that condemned other countries'

\footnotetext{
142 "Sarkozy als Stromverkăufer," Süddeutsche Zeitung, 8 June 2011, Factiva; LeMonde.fr with Agence France-Presse (AFP), "Nicolas Sarkozy égratigne la sortie du nucléaire allemande," LeMonde.fr, 8 June 2011, Eureka.cc.

${ }^{143}$ LeMonde.fr with Agence France-Presse (AFP), "Nucléaire : pour Eric Besson, la France "n'est pas isolée"," LeMonde.fr, 31 May 2011, Eureka.cc.

${ }^{144}$ LeMonde.fr with Agence France-Presse (AFP), "Six Français sur 10 souhaitent sortir du nucléaire," LeMonde.fr, 5 June 2011, Eureka.cc.

${ }^{145}$ Bernard Bigot, "Pourquoi la France a besoin de l'atome," Le Figaro, 3 June 2011, Factiva.
} 
decisions to exit from nuclear energy, such as Switzerland and Italy. ${ }^{146}$ Yet its coverage did emphasize that safety must be the first priority. ${ }^{147}$ Libération was more likely to focus on the government's failures, such as Areva's failure to secure the release of its hostage employees in Niger, or its hypocrisy, such as when it criticized the argument that French nuclear energy is the safest in the world. ${ }^{148}$

\subsubsection{Institutional Structure and the French Government's Response}

'Nuclear destiny' is a rather apropos term as France's institutions and history truly shaped the degree of France's commitment to nuclear energy. Embodying a path dependency argument, one German article compared Germany's 'open' system that allows revision of decisions based on new events or information with France's highly centralized structure that discourages this 'trial and error' assessment, which makes it difficult to escape its long commitment to nuclear energy. ${ }^{149}$ While the future always brings opportunities for change, France's 'closed' institutional structure discouraged the emergence of political opportunities on issues that were contrary to the state's previous path. Encountering no resistance, France's political elite invested heavily in the nuclear industry and helped create a sector that represents an important force in France's economy and a significant source of jobs. Nuclear power plants take significant upfront

\footnotetext{
${ }^{146}$ Marie Maurisse, "En Suisse, la sortie de l'atome alourdira la facture d'électricité," Le Figaro, 30 May 2011, Factiva.

${ }^{147}$ Frédéric De Monicault, "L'EPR de Flamanville devra tirer les leçons de Fukushima," Le Figaro, 1 April 2011, Factiva.

${ }^{148}$ Jean-Christophe Féraud, "Sécurité, EPR, otages ... du pain sur la planche chez Areva," Libération, 18 June 2011, Factiva; Max Armanet, "Le futur impensé," Libération, 29 April 2011, Factiva.

149 Nicolas Bouzou, "Comme en Allemagne, ouvrons le débat sur le nucléaire," LeMonde.fr, 16 June 2011, Eureka.cc. The author was director and founder of Asteres, the Board of analysis of society.
} 
investment, years to construct, and their waste needs to be monitored for centuries. In short, France went 'all in' during its implementation of its civilian nuclear program. Antinuclear dissent is therefore hard for the political elite to tolerate in France given its extensive past investments and the accompanying necessary costs of the industry for years to come.

France's 'closed' institutional structure meant that, as Sarkozy held control of the parliament and the presidency, the French government continued to dismiss criticism of its nuclear program similarly to its past responses to nuclear disasters. ${ }^{150}$ The French government continued to use well-established packages such as 'energy independence' and 'progress,' while expanding to include 'low-carbon alternative' and 'cheap electricity.' As in the past, the government and nuclear industry took the objectives of 'energy independence' and technical prowess for granted and "assume[d] they are synonymous with the public interest."

Despite the government's best efforts, nuclear skepticism seemed to be spreading in the French public. The public began to express discontent with France's nuclear course and all major French newspapers avidly covered the Fukushima disaster and growing nuclear debate. ${ }^{152}$ According to a poll published in the Journal du dimanche on 5 June, more than six in ten French citizens (62\%) wanted to phase out of nuclear energy in 25 to 30 years. Conducted shortly after the German decision was announced, the survey also

\footnotetext{
${ }^{150}$ Dorothy Nelkin and Michael Pollak. The Atom Besieged: Extraparliamentary Dissent in France and Germany (Cambridge, Massachusetts: MIT Press, 1981), 197.

${ }^{151}$ Nelkin and Pollak, The Atom Besieged, 21.

${ }^{152}$ Pascale Hugues, "Die Strahlung, die am Rhein anhielt; Tschernobyl, na und? Warum Deutsche und Franzosen ein so unterschiedliches Verhältnis zur Atomkraft haben," Süddeutsche Zeitung , 5 April 2011, Factiva.
} 
stated that $15 \%$ would support a rapid nuclear exit while $22 \%$ supported the construction of new plants. While a majority of respondents (55\%) were not anxious about French nuclear plants, $45 \%$ were concerned. This finding supports the previous section's idea that, while Fukushima did not provide a political change in France, it prompted a reframing of the nuclear issue. In other words, when the French anti-nuclear movement was dismantled after 1981 , it left a framing gap for three decades so there was no latent narrative for the Fukushima disaster to mobilize in France. However, the Fukushima disaster did prompt heightened French discussion of the nuclear issue, which resulted in the renewal of anti-nuclear framing processes as discussed in the previous section. From about late April onwards, there was a growing coherence of anti-nuclear frames in $L e$ Monde, which formed a narrative comprising both the 'public accountability' and 'real risk' packages. This anti-nuclear framing seemed to encourage the PS and EELV's confidence in challenging the government's pro-nuclear packages, 'energy independence,' 'progress,' and 'cheap electricity.' Thus, while this paper's full argument is that there must be a framing as well as a political opportunity, the Fukushima political opportunity ignited the anti-nuclear framing process in France and this anti-nuclear framing began to enact some change through the political opportunity of the 2012 presidential election.

Unlike in France, German anti-nuclear frames were able to manifest themselves directly after the Fukushima political opportunity and this paper will now consider this case study. 


\subsection{German Political Opportunities: 2011 as 'Super' Election Year}

2011 was a Superwahljahr in Germany, in which about one-third of its states held their elections. There were three state elections in Germany throughout March 2011 in the immediate aftermath of the Fukushima disaster: Saxony-Anhalt on 20 March, and Baden-Württemberg and Rhineland-Palatinate on 27 March. Of these, BadenWürttemberg was the most significant as the governing CDU party had dominated this state's politics since 1948 and the state wielded great influence throughout the country due to its size and economic prosperity.

Merkel's CDU was already in a precarious political position before the Fukushima crisis. The Euro crisis was ongoing but the German public generally supported Merkel's approach to the financial crisis at the time. However, two main national issues plagued Merkel's CDU coalition before the key state elections in BadenWürttemberg and Rhineland-Palatinate on 27 March - her reversal of the nuclear power phase-out and plagiarism allegations against one of her cabinet ministers. As mentioned in the overview of German institutions, the elected state governments select the members of the upper house, the Bundesrat, and the party who controls the majority of state governments has significant control over the legislation that is pursued. In the 2010 North Rhine-Westphalia state elections, the resulting SPD-Green minority government meant that Merkel's CDU lost control of the Bundesrat. This is why the CDU was desperate to do well in these elections and, as it was a 'super' election year, they wanted to be able to control the momentum of each election as it might influence others.

Chancellor Angela Merkel first came to power in the 2005 national elections. She ran against Chancellor Gerhard Schröder (SPD), who was elected in 1998 as part of a 
SPD-Green coalition. ${ }^{153}$ This SPD-Green coalition reached an agreement with energy companies in 2000 for the phase-out of nuclear energy by 2022 . In the 2005 election, Merkel captured a greater share of the vote than the SPD, but neither party's traditional coalition partners had sufficient representation to form a coalition. An agreement was reached between CDU and SPD that Merkel would become Chancellor and the SPD would have half of the Cabinet positions. In the 2009 national elections, the CDU received the largest share of votes and formed a coalition with their preferred partner, the FDP.

On 6 September 2010, Merkel announced delays to the nuclear plant closures achieved by Schröder and his SPD-Greens coalition, which meant an average plant lifetime extension of 12 years from the 2022 deadline. ${ }^{154}$ However, Merkel emphasized that Germany would still completely transition to renewable energy by $2050 .{ }^{155}$ This decision to extend the lifetime of Germany's nuclear power plants proved unpopular even before the Fukushima nuclear disaster, as evidenced by the string of anti-nuclear protests throughout September and October 2010 before the bill enabling the extension was passed.

In February 2011, then Defence Minister Karl-Theodor zu Guttenberg was accused of plagiarism in his doctoral thesis from the University of Bayreuth. Academic titles are closely observed and respected in Germany and, while a doctoral degree in other

\footnotetext{
${ }^{153}$ Ironically, Merkel herself had been Minister for the Environment, Nature Conservation and Nuclear Safety from 1994 to 1998 in Helmut Kohl's fifth Cabinet.

${ }^{154}$ Brian Parkin \& Nicholas Comfort, "Merkel Proposes 12-Year Nuclear Reactor Extension," Bloomberg, 6 September 2010. Retrieved from http://www.bloomberg.com/news/2010-09-05/merkelcoalition-proposes-12-year-nuclear-reactor-extension-for-germany.html on 23 January 2013.

${ }^{155}$ Parkin \& Comfort, "Merkel Proposes 12-Year Nuclear Reactor Extension," 6 September 2010.
} 
Western countries usually suggests the holder intends to pursue a career in academia, "all kinds of professionals in Germany strive for the doctor title - particularly lawyers and medical doctors, who can complete PhDs in as little as a year." ${ }^{, 156}$ Merkel and more than half of her cabinet ministers held doctoral degrees, as well as approximately $20 \%$ of the 620 Bundestag representatives. ${ }^{157}$ In addition, zu Guttenberg was arguably the most charismatic and popular member of Merkel's cabinet. His aristocratic lineage and seemingly glamorous life made him a celebrated CSU politician and media figure, and the popular tabloid magazine Bild even tried to mount a campaign for him to stay on as Minister after the plagiarism allegations. ${ }^{158}$ However, criticism mounted of both $\mathrm{zu}$ Guttenberg and Merkel; the public backlash was sufficiently fierce that zu Guttenberg resigned from all political positions a month later in March 2011. Subsequently, three more politicians from the CSU's coalition partners, the FDP, were accused of doctoral plagiarism, which prolonged the scandal and weakened both parties in advance of the state elections.

It was in the midst of this plagiarism scandal and a mere six months after Merkel's risky political move to extend nuclear power plants that the Fukushima disaster occurred. The German people were captivated by the disaster; Süddeutsche Zeitung noted

\footnotetext{
${ }^{156}$ Harriet Torry, "Another German Minister Felled by Plagiarism Claims," Wall Street Journal Blogs, 11 February 2013. Retrieved from http://blogs.wsi.com/eurocrisis/2013/02/11/another-german-ministerfelled-by-plagiarism-claims/ on 12 March 2013.

${ }^{157}$ Torry, "Another German Minister Felled," 11 February 2013.

${ }^{158}$ Eric Pfanner, "Gloves Off in German Media Scramble," New York Times, 13 March 2011. Retrieved from http://www.nytimes.com/2011/03/14/business/global/14bild.html?pagewanted=all on $12 \mathrm{March}$ 2013; David Crossland, "Guttenberg Fallout: Merkel Loses Heavyweight Minister, Gains Power," Spiegel Online, I March 2011. Retrieved from http://www.spiegel.de/international/germany/guttenberg-falloutmerkel-loses-heavyweight-minister-gains-power-a-748422.html on 12 March 2011.
} 
it was as if Fukushima had triggered another 'figurative tsunami' in the German public consciousness. ${ }^{159}$ It further described the atmosphere in Germany as "a hellish trip back to the seventies [and] eighties - the age of anxiety. ${ }^{, 160}$ Social media meant that a younger generation could track the unfolding of the nuclear disaster in real time, thus promoting the often-quoted 'German angst.' The older generation was angrily reminded of the previous protests after Chernobyl and the fact that little had changed. ${ }^{161}$ The German media began doing follow-up stories on the Chernobyl fallout and its lingering health effects, while major German TV stations changed their primetime programming to focus on the threat of the damaged nuclear power plants. ${ }^{162}$ There were record ratings for television news, as interest in the Fukushima situation was overwhelming. ${ }^{163}$ The public consumed details of the effects of "invisible and treacherous" radiation, and discussions with nuclear experts on worst-case scenarios comparable to Chernobyl. ${ }^{164}$ In at least one

159 "Tsunami fur die Atomlobby; Die Nuklearkatastrophe in Japan wirkt tief auf das Bewusstsein der Menschen in Deutschland - viele wünschen sich einen Ausstieg aus der Kernkraft," Süddeutsche Zeitung, 17 March 2011, Factiva.

${ }^{160}$ Roman Deininger and Holger Gertz, "German Angst; Hans Søllner singt, 60000 demonstrieren, und Guido Westerwelle spricht viel uber die Hundestaffel: Das Wochenende von Japan bescherte Deutschland eine Reise zuruck in die 1980er Jahre," Süddeutsche Zeitung, 14 March 2011, Factiva.

${ }^{161}$ Deininger and Gertz, "German Angst," 14 March 2011; Bernd Kastner, "Alles wieder Wut; Lange haben sich die Atomkraftgegner wie einsame Rufer in der Wuste gefuhlt - nun blicken sie fassungslos nach Japan," Süddeutsche Zeitung, 15 March 2011, Factiva.

${ }^{162}$ Christina Maria Berr, "TV-Programm zum Erdbeben in Japan; Großes Interesse an Sondersendungen," Süddeutsche Zeitung Online, 13 March 2011, Factiva; Christoph Baborka, "Krank und fatalistisch; Wie die Poinger Gomelhilfe die Opfer von Tschernobyl erlebt," Süddeutsche Zeitung, 15 March 2011, Factiva; “„Absoluter Schwerpunkt"; Die Sondersendungen im Fernsehen zur Katastrophe in Japan," Süddeutsche Zeitung, 14 March 2011, Factiva; Rupert Sommer, " TV-Kritik: Anne Will; "Mogglichst rascher Ausstieg"," Süddeutsche Zeitung Online, 14 March 2011, Factiva.

${ }^{163}$ Christina Maria Berr, "Japan: Boom der Nachrichtensendungen; Super-GAU als TV-Highlight," Süddeutsche Zeitung Online, 17 March 2011, Factiva.

164، Unsichtbar und tuckisch; Wie Strahlung auf Menschen wirkt," Suddeutsche Zeitung, 14 March 2011, Factiva; Marion Solletty, "Le pire des scénarios : des rejets comparables à Tchernobyl," LeMonde.fr, 17 March 2011, Eureka.cc. 
state, the Fukushima disaster triggered a run on pharmacies for iodine tablets. While the Bavarian government announced that the intake of iodine tablets was unnecessary, their quick depletion led to concerns on how the state would respond in the event of an actual emergency. ${ }^{165}$

The German media almost immediately shifted the discussion from the situation in Japan to the state of the German nuclear fleet and potential safety threats within its borders. Of the seventeen nuclear power plants in operation, seven - Brunsbüttel, Biblis, Phillipsburg 1, Neckarwestheim 1, Krummel, Isar 1 and Unterweser - had been on the network since the 1970s. These plants were built with now-outdated safety standards and they accounted for the majority of all German incidents in which radioactivity was released into the environment. ${ }^{166}$ Other coverage used the 'real risk' package, referring to a cooling incident at a Swedish nuclear power plant, which was built to the highest security standards, after a power outage to indicate that Germany too could be at risk. ${ }^{167}$ As discussed in the previous section, the 'real risk' package really emphasized that there was no such thing as no risk - nuclear disasters can occur even in technologically advanced states like Japan. For much of the German public, any risk proved to be too much to be tolerated.

${ }^{165}$ Peter Becker, "Hamsterkăufe in Supermärkten; Nach der Reaktorkatastrophe in Tschernobyl vor 25 Jahren kaufen die Burger nur noch Konserven und verzichten auf Frischgemuse," Süddeutsche Zeitung, 11 April 2011, Factiva.

${ }^{166}$ Christopher Schrader, "Kurzschlusse, Blitze und Flugzeugabsturze; Von den 17 verbleibenden Reaktoren in Deutschland haben die acht altesten eine schlechtere Pannenstatistik und geringere Sicherheitsreserven," Süddeutsche Zeitung, 14 March 2011, Factiva.

${ }^{167}$ Schrader, "Kurzschlusse, Blitze und Flugzeugabsturze," 14 March 2011. 
The public mobilized quickly; 60,000 people formed a human chain on 12 March from Stuttgart to Neckarwestheim I in Baden-Wurttemberg to call for an immediate phase-out of nuclear energy ${ }^{168}$ Reportedly, 20,000 more people than expected joined the protest and came from all over Germany. ${ }^{169}$ The German government reacted equally as quickly. Despite Environment Minister Röttgen's rejection of a new discussion on nuclear energy as "completely out of place," Merkel called an emergency meeting on the evening of 12 March. ${ }^{170}$ The SPD-Greens demanded a return to the initial nuclear phaseout plan. ${ }^{171}$ Even some CDU supporters were calling for a reassessment given the costs and risks of nuclear power stations, and that evacuation plans should be published for every municipality to promote calm. Following the crisis meeting with her cabinet ministers, Merkel confirmed that there could not be "business as usual" if such a technologically advanced nation like Japan could experience this kind of nuclear disaster. ${ }^{172}$ She emphasized that Germany sees nuclear energy as an appropriate bridging technology to renewable resources and now was the time to learn the right lessons from Fukushima to validate the safety of German plants. ${ }^{173}$

\footnotetext{
168 "Atomdebatte in Deutschland; 60.000 Atomkraftgegner protestieren in Stuttgart," Süddeutsche Zeitung Online, 12 March 2011, Factiva; "Anti-AKW-Demo im Landle; "Abschaldă statt schwatza"," Süddeutsche Zeitung Online, 12 March 2011, Factiva.

169 "Atomdebatte in Deutschland," 12 March 2011; "Anti-AKW-Demo im Lăndle," 12 March 2011.

170 "Japan nach dem Erdbeben; 10.000 Vermisste in einer Hafenstadt," Süddeutsche Zeitung Online, 12 March 2011, Factiva.

${ }^{171}$ Frédéric Lemaître, "Séisme au Japon: les conséquences politiques et économiques," Le Monde, 15 March 2011, Eureka.cc.

172 "Merkel zur Katastrophe in Japan; "Nicht zur Tagesordnung ubergehen"," Süddeutsche Zeitung Online, 12 March 2011, Factiva.

173 "Merkel zur Katastrophe in Japan," 12 March 2011.
} 
Yet the German public continued to mobilize. According to Google Map, approximately 260 anti-nuclear vigils were held on 14 March, covering virtually the entirety of Germany. ${ }^{174}$ There were repeated demonstrations at many of the older nuclear power plants, such as Isar I and Gundremmingen, throughout the survey period. ${ }^{175}$ There were also weekly protests in major cities like Munich, but attendance declined over the period of study ${ }^{176}$ Religious figures also began commenting on the debate, with several calling for a global shift away from nuclear energy. ${ }^{177}$ On 31 March, 306 scientists wrote an open letter to Merkel to request that she rescind the lifetime extension and move towards a rapid nuclear exit strategy. ${ }^{178}$ This letter is reminiscent of the French 1975 Appel des 400, and poignant for the German public as the Eurobarometer data suggested that scientists were viewed to be the most credible source on nuclear energy.

${ }^{174}$ Johannes Kuhn, "Japan: Die Katastrophe und das Web; Vernetzt in Trauer und Furcht," Süddeutsche Zeitung Online, 14 March 2011, Factiva.

${ }^{175}$ Max Hăgler, "Anti-Atom-Demo am AKW Isar 1; "Jetzt reicht's!"” Süddeutsche Zeitung Online, 14 March 2011, Factiva; "Gundremmingen; Mit Totenkopfen und Ballons gegen Atomkraft," Süddeutsche Zeitung, 14 May 2011, Factiva.

${ }^{176}$ Beate Wild, "Anti-Atomkraft-Demo in München; "Abschalten! Abschalten!"," Süddeutsche Zeitung Online, 15 March 2011, Factiva.

${ }^{177}$ Michael Bauchmuller and Susanne Holl, "Bischøfe gegen Atomstrom; Kirchen fordern rascheren Ausstieg, SPD bietet neuen Energiekonsens an," Süddeutsche Zeitung, 21 March 2011, Factiva; Christopher Schrader, "Fukushima bleibt auf Monate gefahrlich; Rettungskrafte können Strahlungslecks nicht stopfen / Merkel wirbt fur breiten Konsens bei Energiewende," Süddeutsche Zeitung, 4 April 2011, Factiva.

${ }^{178}$ Jeanne Rubner, “Überflussige Bruckentechnik; Offener Brief von Wissenschaftlern," Süddeutsche Zeitung , 1 April 2011, Factiva. 


\subsubsection{The CDU's State Election Concerns}

Following such rapid and extensive public mobilization, it was quickly reported that the government was rethinking the lifetime extension. ${ }^{179}$ Merkel's government had promised the nuclear industry that they could continue to profit for another twelve years, but this policy could ruin CDU-FDP election prospects, particularly in BadenWürttemberg. ${ }^{180}$ Baden-Württemberg Premier Stefan Mappus (CDU) had been supportive of Merkel's unpopular decision to postpone the closures of the nuclear power plants. Baden-Württemberg also had a $45 \%$ stake in Energie Baden-Württemberg (EnBW), which did well in the region through its four reactors and who promised a safety assessment of its facilities after Fukushima. The pre-election polls had Mappus's coalition and the SPD-Greens nearly on par so it was at a point where little things could determine the outcome of the election. ${ }^{181}$ Merkel had previously declared the state elections in Baden-Württemberg as a kind of referendum on technological progress, indeed the future of the whole country (in initial reference to the Stuttgart 21 project), but she would come to regret these words. ${ }^{182}$ The government confirmed on 14 March that there would a three-month suspension of the lifetime extension, which meant the

\footnotetext{
179 "Atompolitik: Konsequenz aus Japan-Katastrophe; Regierung erwăgt Aussetzung der Laufzeitverlängerung," Süddeutsche Zeitung Online, 14 March 2011, Factiva; "Atomkraftwerke in Deutschland; SPD setzt Regierung bei Atompolitik unter Druck," Süddeutsche Zeitung Online, 14 March 2011, Factiva.

${ }^{180}$ Thorsten Denkler, "Bundesregierung ändert Atomkurs; Merkel will Laufzeitverlăngerung aussetzen," Süddeutsche Zeitung Online, 14 March 2011, Factiva.

${ }^{181}$ Roman Deininger, "Gegen den Sog der Ereignisse; In Baden-Wurttemberg kommt der AtomBefurworter Stefan Mappus in Bedrăngnis," Süddeutsche Zeitung, 14 March 2011, Factiva.

${ }^{182}$ Nico Fried, "Merkels Restrisiko," Süddeutsche Zeitung, 14 March 2011, Factiva.
} 
temporary closure of the seven power plants that were built before 1980 pending safety assessments. $^{183}$

Following this announcement, the debate continued on the national level as political parties saw growing public fears about nuclear energy shortly before the state elections. The SPD and Greens called for a nuclear phase-out as well as the immediate and permanent closure of the seven oldest reactors while the CDU and FDP called for calm while plant safety was being assessed. ${ }^{184}$ The SPD and Greens began to organize anti-nuclear energy demonstrations to mobilize support for this cause as well as electoral momentum. ${ }^{185}$

There was a great deal of public mistrust about the CDU's credibility after their sudden nuclear epiphany after Fukushima. ${ }^{186}$ The media reprinted Merkel's past quotes in support of nuclear energy; for example, in 1994, Merkel said that it would be a shame to shift away from this technology given high carbon dioxide emissions but she later

\footnotetext{
${ }^{183}$ Thorsten Denkler, Oliver Das Gupta and Jens Schneider, "Japan und die Folgen: Bundesregierung andert Kurs; Merkel setzt Laufzeitverlangerung aus," Süddeutsche Zeitung Online, 14 March 2011, Factiva; Frédéric Lemaître, "La chancelière Angela Merkel renonce au dégel du nucléaire allemande," LeMonde.fr, 15 March 2011, Eureka.cc; "Regierung setzt Laufzeitverlängerung aus; Kehrtwende in der deutschen Atompolitik; Die Kernkraftwerke Isar 1, Biblis A und Neckarwestheim I könnten demnächst abgeschaltet warden," Süddeutsche Zeitung, 15 March 2011, Factiva; Nico Fried, Peter Blechschmidt,Stefan Braun and Daniel Brössler, "Wir sind doch nicht blöd; Union und FDP weigern sich, eine Sache zu verteidigen, die in Deutschland keine Zukunft hat: Wie sich die Koalition in Berlin plotzlich von der Kernenergie verabschiedet," Süddeutsche Zeitung, 15 March 2011, Factiva.

${ }^{184}$ Daniel Brőssler, "Deutschland streitet wieder uber Kernenergie; SPD-Chef Gabriel: Das Atomzeitalter ist zu Ende / Bundesregierung gegen neue Debatte uber Laufzeiten," Süddeutsche Zeitung, 14 March 2011, Factiva; M. Bauchmuller, B. Dorries and D. Brössler, "Atomunfall in Japan: In Deutschland flammt die Debatte uber die Kernenergie wieder auf; Ein neues altes Problem; Erst war Umweltminister Norbert Röttgen gegen die Laufzeit-Verlängerungen von Atomkraftwerken, dann dafur jetzt holt ihn die Diskussion ein," Süddeutsche Zeitung, 14 March 2011, Factiva.

185 "Demonstration und Mahnwache; SPD und Grine rufen zu Aktionen gegen Atomkraft in Bruck auf," Sulddeutsche Zeitung, 18 March 2011, Factiva.

${ }^{186}$ Damir Fras, "Der Wandel der Kanzlerin - In Offenburg versucht Angela Merkel, ihren Kurswechsel zu erklären - Katastrophe in Japan," Berliner Zeitung, 17 March 2011, Factiva.
} 
characterized nuclear energy as a 'bridging' technology in $2011 .^{187}$ Furthermore, as some articles questioned, if the CDU did not reject nuclear energy after Chernobyl, why now? ${ }^{188}$ Other commentators agreed that Merkel had established a great deal of credibility over the previous five years but that her 2010 nuclear lifetime extension threatened not only her own credibility, but also that of the CDU. ${ }^{189}$ The public was also outraged by the government's apparent lie in 2010 that a nuclear phase-out by 2022 was unrealistic in order to justify the nuclear plant lifetime extension. That such a phase-out all of a sudden seemed possible alienated the public who took it as a further indication of election campaigning. ${ }^{190}$ Added to these considerations was Merkel's demonstrated record of catering to electoral issues such as in Germany's refusal to participate in the international community's Libya intervention, which was taken to be clearly related to electoral concerns. ${ }^{191}$

Perhaps as a result of this mistrust, the Saxony-Anhalt election on 20 March was not positive for the CDU and FDP. While the CDU managed to maintain its leading party status in Saxony-Anhalt, its FDP partner was wiped out, losing all nine seats that it had previously won in the 2006 election. Furthermore, the Greens gained all nine seats that

\footnotetext{
187 "Zitate zur Atomdebatte; Hoch lebe die Kernkraft, die Kernkraft muss weg!" Süddeutsche Zeitung Online, 16 March 2011, Factiva.

${ }^{188}$ Annette Ramelsberger, "Kommentar; Atom-Paulus, Öko-Saulus," Süddeutsche Zeitung, 18 March 2011, Factiva. CSU politicians particularly denied Chernobyl's effects within its borders and continued to support nuclear energy development in Bavaria.

${ }^{189}$ Nico Fried, "Angela Merkel und die Atomkraft; Die Stimmungskanzlerin," Süddeutsche Zeitung Online, 16 March 2011, Factiva.

190 "Abschalten! Sofort! Die plötzliche Kehrtwende in der deutschen Atompolitik macht ihre Protagonisten völlig unglaubwurdig," Süddeutsche Zeitung, 19 March 2011, Factiva.

${ }^{191}$ Patrick Saint-Paul, L'Allemagne a fait faux bond à l'ONU pour des raisons électorales," Le Figaro, 19 March 2011, Factiva.
} 
the FDP had lost. ${ }^{192}$ The CDU clearly did not have momentum going into the remainder of the March elections, and the FDP were on track to be wiped from the electoral map. Following these election results, Merkel ramped up her nuclear rhetoric. Unfortunately for Merkel, Minister Rainer Brüderle's (FDP) rumoured comments to the nuclear industry that dismissed the suspension as an election stunt surfaced a few days before the 27 March elections. ${ }^{193}$ Many voters saw this as confirmation that in fact the new policy was not a result of an epiphany and rational consideration, but only of shortterm tactics, which was extremely damaging to Merkel's credibility. One survey had $70 \%$ of respondents stating that they thought the three-month moratorium was a mere election trick. ${ }^{194}$ The opposition pounced on this Brüderle incident to crow that Merkel was more afraid of elections than radiation. ${ }^{195}$ Still, Merkel called for a new national debate on nuclear safety through the creation of an Ethics Commission, comprising scientists, church representatives, former politicians and trade unionists, who would work in parallel with the technical work of a nuclear safety commission that would evaluate the status of

\footnotetext{
${ }^{192}$ Michael Bauchmuller, "Von Spătzulndern und Fruhaufstehern; Die CDU redet ihr Ergebnis schön, die Liberalen sprechen sich Mut zu, die SPD schaut nach vorne - nur die Grunen freuen sich im Hier und Jetzt," Süddeutsche Zeitung, 21 March 2011, Factiva; Katja Auer, "Mitregieren bringt keine Bonuspunkte; Wahrend sich die CSU wachsenden Zuspruchs erfreut, schwinden die Sympathien der Burger im Freistaat fur die FDP," Süddeutsche Zeitung, 22 March 2011, Factiva; "Nachlese: Landtagswahl in Sachsen-Anhalt; CDU und SPD umgarnen sich," Süddeutsche Zeitung Online, 20 March 2011, Factiva.

${ }^{193}$ Daniela Vates, Markus Sievers, and Damir Fras, "Bruderle wird zum Restrisiko - Minister soll AKW-Moratorium mit Wahlkampftaktik begrundet haben / Dementi im Parlament / CSU: Glaubwürdigkeit der Union untergraben / Zwist in der Koalition," Berliner Zeitung, 25 March 2011, Factiva.

194 Jan Hildebrand, Thorsten Jungholt, and Daniel Friedrich Sturm, "Für das Protokoll: Das AtomMoratorium ist (kein) Wahlkampf," Die Welt, 25 March 2011, Factiva.

195 Jakat and Das Gupta, "Bruderle, das Moratorium und der Wahlkampf," 24 March 2011; Prantl, "Klingeling, hier kommt die Kanzlerin," 25 March 2011.
} 
Germany's nuclear power plants. ${ }^{196}$ Nuclear proponents condemned the creation of this 'ethics' committee, as they argued that decisions should be made on objective criteria, such as feasibility, costs, and economic impacts, and this committee had little expertise on energy policy. Fuchs argued that no other country was considering a nuclear exit until after the results of pan-European stress tests and also pointed to the example of Sweden where, after a very cold winter in which hydroelectric dams froze and some citizens froze to death, a nuclear phase-out was abolished. ${ }^{197}$

These proponents' concerns were ignored by the public according to Süddeutsche Zeitung's coverage. The Fukushima incident caused more support for renewable energy in Germany, with several articles embodying a 'soft paths' package. ${ }^{198}$ Politicians began supporting renewable energy projects that they had previously refused and preparing for changes to construction law to allow the easier installation of wind turbines and solar panels. ${ }^{199}$ Other coverage reiterated German prowess in the development of solar energy, with solar energy as a percentage of Germany's energy mix expected to almost quadruple

${ }^{196}$ Michael Bauchmuller and Stefan Braun, "Merkel sucht neuen Atomkonsens; Kommission aus Bischøfen, Wissenschaftlern und ehemaligen Ministern soll Streit uber Kernenergie schlichten," Süddeutsche Zeitung, 23 March 2011, Factiva.

${ }^{197}$ Christian Fuchs, "Energiewende und German Angst; Nach dem Atomausstieg furchten manche den Niedergang des Hochtechnologie-Standorts Deutschland - andere sind froh, dass neue Wege aufgezeigt warden," Süddeutsche Zeitung, 3 June 2011, Factiva.

198 Angelika Slavik, "Flucht in Wind und Sonne; Deutsche entdecken ihre große Liebe zum Ökostrom," Süddeutsche Zeitung, 17 March 2011, Factiva.

${ }^{199}$ Daniel Glaßer, "Ruckenwind fur Windkraft; Erstmals befurworten die beiden Dachauer Landtagsabgeordneten offentlich das umstrittene Vorhaben bei Odelzhausen," Süddeutsche Zeitung, 16 March 2011, Factiva; Michael Bauchmuller, "Mehr Klimaschutz im Baurecht; Plăne der Bundesregierung: Kommunen sollen zusătzliche Flăchen fur Windrăder und Solaranlagen ausweisen," Süddeutsche Zeitung, 16 May 2011, Factiva. 
by $2020 .^{200}$ Furthermore, contrary to proponents of the 'energy independence' or 'cheap electricity' packages, some articles argued that there were no anticipated energy shortages or long-term price increases as a result of a German nuclear exit. ${ }^{201}$ On 21 May, Germany only had four of its 17 nuclear power plants in operation with no threat to the power supply. ${ }^{202}$ Some consultants concluded that, while there would be a temporary price increase, a nuclear phase-out by 2020 would not distort prices over the long-term. ${ }^{203}$ In terms of climate concerns or the 'low carbon alternative' package, Geoffron asserted that, while greenhouse emissions may rise in Germany in the first two years of an energy transition, renewable energy and energy efficiency would soon compensate for this rise. $^{204}$

On 27 March, the Baden-Württemberg and Rhineland-Palatinate elections were finally held. The night before the elections, there were nationwide protests with more than 100,000 protesting in Berlin. ${ }^{205}$ After the setbacks endured in the Saxony-Anhalt

\footnotetext{
${ }^{200}$ Ralph Diermann, "Sonnenkraft fur ubermorgen; Deutsche Forschungsinstitute sind weltweit fuhrend bei der Weiterentwicklung der Solarenergie," Süddeutsche Zeitung, 4 June 2011, Factiva; Ralph Diermann, "Mehr Sonne im Strom; Der Anteil der Photovoltaik am Strommix in Deutschland soll sich bis 2020 fast vervierfachen. Forscher und Unternehmen lehnen Deckelung des Anlagen-Zubaus ab," Süddeutsche Zeitung, 6 June 2011, Factiva.

${ }^{201}$ Michael Konig, "Atompolitik: Schwarz-gelbe Kehrtwende; Wo geht's denn hier zum Engpass?" Süddeutsche Zeitung Online, 16 March 2011, Factiva.

${ }^{202}$ Michael Bauchmuller, "Von diesem Wochenende an; Mehr Ökostrom als Atomenergie; Weitere Meiler zur Wartung abgeschaltet / Jetzt sind nur noch vier der 17 Kernkraftwerke am Netz," Süddeutsche Zeitung, 21 May 2011, Factiva.

${ }^{203}$ Michael Bauchmuller, "Das Preisrătsel; Wie teuer der Strom wird, zăhlt zu den Unbekannten des Atomausstiegs. Jetzt geben die Stadtwerke uberraschend Entwarnung," Süddeutsche Zeitung, 11 May 2011, Factiva.

${ }^{204}$ Thomas Baietto, "Nucléaire français : les propos de M. Besson passés au crible," LeMonde.fr, 1 June 2011, Eureka.cc.

${ }^{205}$ Susanne Horr, "Die neue Protestbewegung - Mehr als 100000 Menschen demonstrierten fur einen schnellen Atomausstieg. Viele Neulinge waren dabei," Berliner Zeitung, 28 March 2011, Factiva.
} 
election, the CDU-FDP coalition hoped to regain some lost ground during these elections. The CDU had dominated politics within Baden-Württemberg since 1948, yet the Greens won their strongest election result ever in this election. While there were other issues that encouraged this victory, particularly those concerning Stuttgart 21, the abolition of nuclear energy was a huge mobilizing force on the electorate. ${ }^{206}$ Upon their victory, the Greens committed to the phasing out of nuclear energy as soon as possible. ${ }^{207}$ While Merkel's CDU actually gained three seats since the 2006 Rhineland-Palatinate state elections, her FDP coalition partners were decimated and lost all 10 seats that they had won in 2006. The Greens also gained in Rhineland-Palatinate, winning 18 seats versus the zero won in 2006. This Green momentum continued for the rest of the year; in September 2011, around 20 percent of Germans polled support of the Greens and by October 2011, the Greens were represented in every state parliament. ${ }^{208}$ An interesting note about these elections is that a million more people voted in Baden-Württemberg than in 2006 , with a greater participation of younger voters. The Greens benefitted the most from this younger demographic as they were selected by 1.2 million voters (a gain of

\footnotetext{
${ }^{206}$ Stuttgart 21 is part of an urban development program in Stuttgart, which focuses on the development of several new railway lines and a refurbished central station. Opponents were against the project for a range of reasons, most notably environmental and financial given several cost overruns.

${ }^{207}$ Jakob Schlandt, "KONZERNUMBAU - Die Ökopartei kontrolliert jetzt den Atom-Dinosaurier EnBW," Berliner Zeitung, 29 March 2011, Factiva.

${ }^{208}$ Nicholas Kulish, "Greens Gain in Germany, and the World Takes Notice," New York Times, 1 September 2011. Retrieved from http://www.nytimes.com/2011/09/02/world/europe/02greens.html? r=2\&pagewanted=all\& on 20 February 2013; LeMonde.fr with Agence France-Presse (AFP), "Allemagne : percée des Verts et défaite historique de la CDU dans son propre fief," LeMonde.fr, 28 March 2011, Eureka.cc.
} 
740,000 voters since 2006 ) of whom very few were older than sixty. ${ }^{209}$ While there may have been other issues, $40 \%$ of respondents on a survey stated that nuclear energy was a deciding issue in their vote. ${ }^{210}$

While the losses of the CDU and FDP may have been influenced by many factors, both parties clearly laid the blame on the Fukushima disaster for relegating all other issues to the background. ${ }^{211}$ Baden-Württemberg CDU General Secretary Thomas Strobl unequivocally stated, "The state election was held in Japan."212 Defeated leader Mappus wistfully remembered, "Two weeks ago, the CDU was still [polling] at 42 percent."213 SPD leader Sigmar Gabriel interpreted the election results as sealing the fate of nuclear energy in Germany. ${ }^{214}$ On 3 April, Foreign Minister Guido Westerwelle announced that he was resigning as FDP leader after the party's repeated electoral failures, but would remain as Foreign Minister. FDP failed to win any seats in the Saxony-Anhalt and Rhineland-Palatinate elections, while only narrowly exceeded the $5 \%$ threshold of votes required in Baden-Württemberg. ${ }^{215}$ An article in Die Welt noted that these results had

${ }^{209}$ Felix Berth, "Jung, sprunghaft, grun; Die Atomdebatte hat viele Nichtwăhler mobilisiert," Süddeutsche Zeitung, 29 March 2011, Factiva.

${ }^{210}$ Berth, "Jung, sprunghaft, grün," 29 March 2011.

${ }^{211}$ Robin Alexander, "CDU: Kernkraft ist schuld an Niederlage," Die Welt, 29 March 2011, Factiva.

212 "Reaktionen nach der Wahl; "Schwarz-Gelb ist abgewălt"," Süddeutsche Zeitung Online, 27 March 2011, Factiva.

213 "Eins auf die Mutze; CDU und FDP lernen nun auch dort, wo sie seit jeher auf Siege abonniert waren, was eine herbe Niederlage ist," Süddeutsche Zeitung, 28 March 2011, Factiva.

214 "Machtwechsel in Baden-Württemberg; Ein Grüner wird Ministerpräsident; Winfried Kretschmann will Koalition mit der SPD bilden / Wahlverlierer Mappus: Bitterer Tag fur die CDU," Süddeutsche Zeitung, 28 March 2011, Factiva.

\footnotetext{
${ }^{215}$ LeMonde.fr with Agence France-Presse (AFP), "Guido Westerwelle quitte la tête du Parti libéral,"
} LeMonde.fr, 4 April 2011. Eureka.cc. 
impacts elsewhere in the country as, prior to Fukushima, the CDU seemed willing to risk an early ballot in North Rhine-Westphalia but post-Fukushima tactics changed everything. $^{216}$

\subsubsection{The Nuclear Phase-out}

Following these disappointing election results, Merkel began focusing on repairing the CDU's credibility nationally. Merkel's Ethics Commission met for the first time on 4 April, with representatives from politics, science, and civil society as well as three Christian representatives. ${ }^{217}$ For parliamentarians, the Ethics Commission gave the impression that their services were no longer needed; nevertheless, a CDU-FDP coalition working group was struck on 7 April. ${ }^{218}$ The parallel technically-focused nuclear safety commission concluded that German nuclear plants' safety was generally robust but there were concerns about the seven oldest plants. Their report concluded that most of these older plants were vulnerable to the same cooling challenges as Fukushima. ${ }^{219}$ This result was generally to the CDU's liking as it was consistent with their promotion of German plants as safe as well as their suspension of the extension of the seven oldest plants. ${ }^{20}$

${ }^{216}$ Kristian Frigelj, "Die CDU traut sich nicht mehr," Die Welt, 18 May 2011, Factiva.

217 "Ethikkommission zur Atompolitik; "Ein biblisches Gebot"," Süddeutsche Zeitung Online, 4 April 2011, Factiva.

${ }^{218}$ Thorsten Denkler, "Zweifel am Atomkurs der Koalition; "Atomkraft, nein danke" - Danke, nein!," Süddeutsche Zeitung Online, 8 April 2011, Factiva.

${ }^{219}$ Steven Geyer and Jacob Schlandt, "Sieben Atommeiler auf einen Streich - Umweltminister Rottgen will nach Stresstest die ăltesten Kraftwerke vom Netz nehmen - Sie sind nicht gegen Flugzeugabsturze gesichert / Genereller Sofortausstieg abgelehnt," Berliner Zeitung, 18 May 2011, Factiva.

${ }^{220}$ Thorsten Denkler, "Expertenbericht zur Reaktorsicherheit; Rottgens Wunschergebnis," Süddeutsche Zeitung, 17 May 2011. Factiva; Michael Bauchmuller, "Reaktorexperten prăsentieren Gutachten; Schlechte Noten fur sieben Atomkraftwerke; Alte Meiler bei einem Flugzeugabsturz nicht sicher / Rottgen: Insgesamt sind die deutschen Anlagen aber „robust“,"Süddeutsche Zeitung, 18 May 2011, Factiva. 
Critics however felt that the technical audit was vague on many points and often was subject to interpretation. ${ }^{221}$ This perception was perhaps echoed in the 22 May state election in Bremen in which the SPD-Greens continued their previous coalition with the Greens gaining seven votes. The CDU lost three seats while the FDP was once again wiped out and lost all five of its seats. ${ }^{222}$

Further cause of anguish for the CDU was confirmation that the Ethics Commission concluded a German nuclear phase-out was possible by 2021 at the latest. ${ }^{223}$ On 28 May, more than 150,000 people protested across Germany to encourage a nuclear phase-out, including 30,000 in Berlin alone. ${ }^{224}$ After almost 13 hours of intense negotiations, the government announced on 30 May that the majority of German nuclear power plants would be off the grid by 2021 with a complete exit no later than 2022 . Three reactors would keep running until 2022 if there were difficulties in the energy transition strategy. This safety buffer was largely insisted on by new Economy Minister and FDP leader Philipp Rösler. The seven oldest power plants and the problematic Krummel plant were to be removed from the network immediately. Surprisingly, the coalition also remained committed to the fuel tax, which now required companies to pay

\footnotetext{
${ }^{221}$ Michael Bauchmuller, "Eine Frage der Auslegung; Erdbeben, Hochwasser, Terrorangriffe: Der Prufbericht zur Sicherheit deutscher Kernkraftwerke ist in vielen Punkten vage," Süddeutsche Zeitung, 18 May 2011, Factiva.

${ }^{222}$ Thorsten Denkler, “Analyse - Folgen der Bremen-Wahl; Etappensieger auf dem Weg nach Berlin," Süddeutsche Zeitung Online, 23 May 2011, Factiva.

${ }^{223}$ Michael Bauchmuller, "Energiewende; Ethikkommission empfiehlt Ausstieg binnen zehn Jahren," Süddeutsche Zeitung Online, 28 May 2011, Factiva; Claudia Ehrenstein, "'Nur der Ausstieg schafft Sicherheit"," Die Welt, 11 May 2011, Factiva.

224 "Bundesweite Proteste gegen Atomkraft; "AKW? Neee!"," Süddeutsche Zeitung Online, 28 May 2011, Factiva; "Vor Koalitionsgipfel; Zehntausende demonstrieren gegen Atomkraft," Süddeutsche Zeitung Online, 28 May 2011, Factiva.
} 
about $€ 1.3$ billion (down from 2.3 billion) per year to account for the premature closing of the seven oldest reactors. Merkel had originally recommended 2021 as the exit date, which is a little earlier than the original SPD-Green $2022 / 23$ phase-out. ${ }^{225}$ Critics denounced Merkel's catering to the energy lobby and new FDP leader Rösler's suggestion to postpone the deadline slightly and maintain some safety buffer plants connected to the grid. ${ }^{226}$

This German narrative has been largely constructed from Süddeutsche Zeitung's coverage, but Berliner Zeitung and Die Welt's analysis varied somewhat from this narrative and these differences will be explored now.

\subsubsection{Coverage by Berliner Zeitung and Die Welt}

Berliner Zeitung and Die Welt varied far more from Süddeutsche Zeitung's coverage than their French counterparts did from Le Monde in the previous section. Berliner Zeitung's coverage depicted the nuclear phase-out as not happening quickly enough. On 14 March, an article was already calling for a return to the phase-out. ${ }^{227}$ Several articles accused Merkel and the CDU of not proceeding quickly enough out of a desire to protect industry interests instead of the people. ${ }^{228}$ Several articles also raised

\footnotetext{
225 "Koalitionsgipfel im Kanzleramt; Regierung plant Atomausstieg bis spătestens 2022," Süddeutsche Zeitung Online, 29 May 2011, Factiva.

${ }^{226}$ Matthias Kolb, "Kritik an Ausstiegsbeschluss; "Die Hinterturchen sind riesige Tore fur die Atomkonzerne"," Süddeutsche Zeitung Online, 30 May 2011, Factiva.

${ }^{227}$ Joachim Wille, "Zuruck zum Atom-Ausstieg!," Berliner Zeitung, 14 March 201 1, Factiva.

${ }^{228}$ Joachim Wille, "Atomausstieg im Schleichgang," Berliner Zeitung, 31 May 2011, Factiva; Markus Sievers, "Merkel will Atom-Konzerne schonen - Kanzleramt plant, Brennelementesteue r fur AKWBetreiber zu streichen / Widerspruch aus der FDP / Umweltbundesamt: Ausstieg bis 2017 moglich / EU einig uber Sicherheitstests," Berliner Zeitung, 26 May 2011, Factiva; Steven Geyer, "Bundesregierung Umsteuern mit leichter Verspătung," Berliner Zeitung, 9 May 2011, Factiva.
} 
concerns that, despite Germany going on the right track, it was surrounding by several reactors in neighbouring countries. 229

Articles in the Berliner Zeitung also rejected insinuations that Germany's energy supply was at risk. On 5 May, an article emphasized that only six reactors were on the network that day for various reasons and there had been no energy supply problems. ${ }^{230}$ Another article described a new study that rejected the assertion that nuclear and coal power are the only cheap options as hydroelectric and wind power are the cheaper options in the long run. ${ }^{231}$

In contrast, the conservative Die Welt was particularly critical of the phase-out with one article describing it as a hasty political choice with no rational reflection or discussion. ${ }^{232}$ Other articles criticized the CDU's loss of credibility, given its Libyan refusal and nuclear exit, through the sacrificing of its core ideals of security and finance; as Fukushima had offered no new information about the risks of nuclear energy, Die Welt's coverage argued that the CDU's rapid shift on the issue just underscores its

\footnotetext{
${ }^{229}$ Felix Helbig, "Auf der anderen Seite - Seit dem Ungluck von Fukushima sind in Deutschland viele fur einen schnellen Ausstieg aus der Atomenergie. Einige der anfalligsten Meiler Europas stehen allerdings dicht hinter der Grenze in Nachbarländern. - Das fuhrt zu Konflikten, immer wieder. Doch die AKWGegner vor Ort sind zăhe Kämpfer," Berliner Zeitung, 14 April 2011, Factiva; Hannes Gamillscheg, P Frank Herold, Thorsten KnufP, and Axel Veiel, "Nachbarn bauen weiter auf Atomenergie - Die EU beschließt Sicherheitschecks in allen Kraftwerken, aber einige Lănder sehen keine Notwendigkeit zum Umdenken," Berliner Zeitung, 16 March 2011, Factiva; Gerhard Gnauck, "Polen will die Unabhăngigkeit," Die Welt, 26 March 2011, Factiva.

${ }^{230}$ Jakob Schlandt, "Deutschland fast atomstromfrei - Nur sechs von 17 Meilern am Netz und es gibt kein Problem," Berliner Zeitung, 5 May 2011, Factiva.

${ }^{231}$ Jakob Schlandt, "Studie - Wind- und Wasserkraft am billigsten," Berliner Zeitung, 18 April 2011, Factiva.

${ }^{232}$ Thomas Schmid, "Tollkuhner Ausstieg," Die Welt, 6 June 2011, Factiva; Michael Sturmer, "Keine Vision, nirgends," Die Welt, 11 April 2011, Factiva; Daniel Wetzel, "Netzbetreiber warnen vor Blackout im Winter," Die Welt, 23 May 2011, Factiva; Daniel Wetzel, "Glucksspiel statt Sicherheit," Die Welt, 23 May 2011, Factiva; Daniel Wetzel, "Kampf gegen den Blackout," Die Welt, 20 May 2011, Factiva.
} 
reaction as an electoral ploy to cater to voter panic and fear. ${ }^{233}$ Another article blamed the German media for propagating fear and argued that the change of German opinion on nuclear energy was the result of specific media coverage in Germany, which gave accidents a meaning that they did not have in other countries. ${ }^{234}$ Another article criticized the hysterics, lack of professionalism, and insensitivity of the German reaction compared to the stoicism of the Japanese in the face of their suffering. ${ }^{235}$

Die Welt's coverage also focused on Germany's energy supply. Several articles examined stresses to the power grid and possible blackouts. ${ }^{236}$ Another Die Welt article lamented the rise of energy prices since the three-month moratorium and noted that France and the Czech Republic were currently supplementing Germany's energy supply following this closure with their own nuclear energy. ${ }^{237}$ Another article questioned the overreliance on renewable energies, advocating instead a mix of systems for energy security. ${ }^{238}$

This wider divergence of media narratives in Germany than in France could be a result of Germany's longer history of anti-nuclear framing. In other words, anti-nuclear framing had been such a status quo for a long period of time in Germany so other

\footnotetext{
${ }^{233}$ Gerd Held, "Der große Ausstieg," Die Welt, 3 June 2011, Factiva; Thomas Schmid, "Ausnahmezustand, nein danke," Die Welt, 5 April 2011, Factiva.

${ }^{234}$ Mathias Kepplinger, "Phantomangst Atomangst," Die Welt, 11 April 2011, Factiva.

${ }^{235}$ Reinhard Zöllner, “Apokalypse jetzt!,” Die Welt, 28 March 2011, Factiva.

236 “Atomausstieg stresst das Stromnetz," Die Welt, 3 June 2011, Factiva.

${ }^{237}$ Daniel Wetzel and Carsten Dierig, "Deutschland braucht Atom-Hilfe," Die Welt, 5 April 2011,

${ }^{238}$ Gerd Held, "Dem Atom eine Chance," Die Welt, 17 May 2011, Factiva.
} Factiva. 
perspectives had the opportunity to develop nuances or counter arguments to this framing.

\subsubsection{Germany's Response and the Influence of Elections}

This German case is truly the personification of this paper's argument that there must be both a framing of the issue and a political opportunity for nuclear policy change to occur, with historical experience, elite consensus, and public opinion playing a mitigating role. Fukushima was the major mobilizing political opportunity but this was not the only political opportunity. As mentioned, Germany was in the midst of a 'super' election year but there were also several other political opportunities that appeared during this time, namely arising from Germany's relationship with Japan, the anniversaries of previous nuclear disasters, and its history of previous anti-nuclear mobilizations.

Elections always present a political opportunity in democratic states, but the extent of this opportunity is determined by the state's institutional structure. First, Germany's federal nature and ambiguous division of responsibilities between the two levels of government meant that the winners of state elections hold far more influence than those of regional elections in France. Secondly, Germany's electoral system allows proportional representation, which makes it easier for newly formed groups to enter the system. ${ }^{239}$ This was important for the Greens' entry into German politics and, by the virtue of their entry, they changed the way the system interacted with the anti-nuclear movement as it "stabilised and strengthened [this base] as [a] durable force[...] in

\footnotetext{
${ }^{239}$ Peter Wagner, "Contesting Policies and Redefining the State: Energy Policy-making and the Antinuclear Movement in West Germany," States and Anti-Nuclear Movements, ed. Helena Flam, (Edinburgh: Edinburgh University Press, 1994), 276.
} 
society. ${ }^{240}$ This stabilization allowed the Greens to maintain their presence as a background player until the Fukushima political opportunity enabled them to parlay increased attention into an electoral breakthrough in Baden-Württemberg.

In January 2011, Germany and Japan announced that 2011 would be a year full of events to celebrate "150 Years of Friendship Between Germany and Japan" as a commemoration of the Prussian-Japanese trade and friendship treaty signed on 24 January $1861 .{ }^{241}$ This meant that more German artists, performers, and students were planning to head to Japan during this year. Consequently, media coverage of the Fukushima nuclear disaster spilled beyond the international and political sections into the culture, literature, and life and style sections as planned performances were cancelled or as international students returned to Germany. These planned events had also created networks of individuals who were then appropriated for memorial services and vigils for Japanese victims of the 11 March tri-disaster, which generated more newspaper stories and media coverage. In essence, this meant a German individual could not read any daily issue of Süddeutsche Zeitung without some mention of either Japan or Fukushima and this media saturation was reflected in other newspapers as well. This coverage not only served to saturate the German public with the implications of the Fukushima nuclear disaster, but also served to further enforce the link between Germany and Japan in any framing process through this presentation of a shared cultural identity. This created a political opportunity in that more of the German public could 'put themselves in the

\footnotetext{
${ }^{240}$ Wagner, "Contesting Policies and Redefining the State," 290.

${ }^{241}$ Federal Foreign Office of Germany. "Germany and Japan: 150 Years of Friendship," Federal Foreign Office Website (last updated on 20 January 2011). Retrieved from http://www.auswaertigesamt.de/EN/Aussenpolitik/RegionaleSchwerpunkte/Asien/AktuelleArtikel/110119-150J-DtJapan node.html on 25 February 2013.
} 
shoes' of their Japanese counterparts, and subsequently chose to reject the potential consequences of a nuclear disaster.

German anti-nuclear opposition also had the political opportunities of the anniversaries of two of the worst nuclear disasters on record: the $32^{\text {nd }}$ anniversary of Three Mile Island on 28 March and the $25^{\text {th }}$ anniversary of Chernobyl on 26 April. The $32^{\text {rd }}$ anniversary of the Three Mile Island nuclear incident proved to be less of a rallying point for media and opposition in both countries compared to the $25^{\text {th }}$ anniversary of Chernobyl on 26 April. For both French and German sources, these anniversaries provided an opportunity for the media to provide an update on these disasters, which underscored the long duration of their health and environmental effects (Chernobyl in particular). ${ }^{242}$ This synergy was likely augmented by the announcement less than two weeks prior that Fukushima now joined Chernobyl as the only recorded Level 7 incidents on the International Nuclear Event Scale. Reports note that more than 140,000 people rallied on the eve of Chernobyl's 25th anniversary for the nuclear exit in Germany but also in France, particularly at Fessenheim. ${ }^{243}$ Opposition parties also used these anniversaries as opportunities to mobilize more people through commemorative events and lecture series beginning far before the anniversary. They also likely parlayed this mobilization into some electoral success.

\footnotetext{
242 "25 Jahre nach dem Super-GAU; Ex-Tschernobyl-Direktor warnt vor neuer Katastrophe," Suddeutsche Zeitung Online, 8 April 2011, Factiva; Claudia Ehrenstein, "25 Glockenschlage zum Gedenken an Tschernobyl-Opfer," Die Welt, 27 April 2011, Factiva; Michael G. Meyer, "“Wir sind alle gesund" - So wie heute die Verantwortlichen in Fukushima verschleierten vor 25 Jahren die Behörden das Ausmaß der Kernschmelze in Tschernobyl," Berliner Zeitung, 26 April 2011, Factiva; Corinne Bensimon, "Chocs de chiffres," Libération, 27 April 2011, Factiva.

243 "Les anti-nucléaires défilent," LeMonde.fr, 26 April 2011, Eureka.cc.; "Tausende protestieren gegen Kernkraft," Die Welt, 26 April 2011, Factiva.
} 
Anti-nuclear dissent also benefitted from political opportunities through events that harkened back to previous anti-nuclear mobilizations. While both countries' media provided significant coverage around these nuclear anniversaries, they made a larger impact in Germany due to its history of anti-nuclear protest and the specific tactics used in German anti-nuclear protest. In 2011, the Christian Easter weekend fell just before Chernobyl's anniversary on 26 April. ${ }^{244}$ In the 1970 s and 1980s, the Easter Peace Marches were a huge demonstration of the anti-nuclear opposition (among other issues). In recent years however, the popularity of the Easter March movement had declined from its eighties heyday. However, the Fukushima disaster galvanized the public to organize more than 80 events from Easter Saturday to Easter Monday across the country. ${ }^{245}$ Organizers estimated the number of participants to be around 120,000 in over 100 cities. ${ }^{246}$ Therefore, historical experiences played a huge role in shaping present day political opportunities.

As such, not only were anti-nuclear frames prevalent in Germany's history and could thus be readily drawn upon after the Fukushima disaster, there were many political opportunities through which these frames could manifest themselves. Yet the particular importance of the state elections as political opportunities in the German nuclear exit

\footnotetext{
${ }^{244}$ Ash Wednesday, the start of Lent, was on 9 March and Easter Sunday was on 24 April. In reviewing articles in the Süddeutsche Zeitung, a significant number of vigils and fundraising activities for Japanese tri-disaster victims were observed during this time. These announcements were not the focus of this paper's research, but it is worth noting that this religious observance period may have acted as another avenue for framing processes for the German public.

${ }^{245}$ Florian Fuchs, "Protest hat Konjunktur; Wegen Fukushima haben die Ostermärsche Zulauf," Süddeutsche Zeitung , 23 April 2011, Factiva; "Renaissance der Ostermärsche - Demonstranten wenden sich gegen Atomkraft, Milităreinsătze und Rustung," Berliner Zeitung, 26 April 2011, Factiva.

246 "Zehntausende protestieren gegen Atomkraft; Anti-AKW-Bewegung und Friedensaktivisten zeigen ihren Unmut uber die Bundesregierung / Kirchen fordern solidarischen Lebensstil," Süddeutsche Zeitung, 26 April 2011, Factiva.
} 
cannot be overestimated as the cleavages in the political elite's past and current approaches to nuclear energy were given an opportunity to manifest themselves in representative political change with subsequent policy changes. The importance of political elite consensus in both France and Germany will now be considered.

\subsection{Elite Consensus: Reversals of Trends in France and Germany}

The past consensus of the French and German political elite was an important factor in shaping their immediate reactions to the Fukushima disaster. During previous anti-nuclear mobilizations, the French political elite formed a firm consensus in favour of nuclear energy. In Germany however, the field was more evenly divided with the CDUFDP supporting nuclear energy and the SPD-Greens against. However, the Fukushima disaster prompted a reversal of this trend as the PS suffered internal divisions on nuclear energy (encouraged by the EELV) while the UMP remained firmly in favour. In contrast, Germany's parties shifted so almost all articulated their official position as against nuclear energy (although there remained some internal dissent on this position). The French and German cases will now be examined separately in order to provide a more complete analysis.

\subsubsection{France's Crumbling Nuclear Consensus}

In its initial response to the Fukushima disaster, French political leaders banded together to defend the nuclear status quo. The National Front maintained its pro-nuclear stance and stated that, while it believed it was important to provide the public with information on these issues, the public should not heed the "anti-nuclear Cassandras."247

\footnotetext{
${ }^{247}$ LeMonde.fr with Agence France-Presse (AFP), "Le FN contre les manipulations des "Cassandre anti-nucléaires"," LeMonde.fr, 15 March 2011, Eureka.cc.
} 
Sarkozy's government criticized the anti-nuclear rhetoric as trying to 'indecently' capitalize on Japan's suffering. ${ }^{248}$ Prominent PS members also dismissed nuclear opponents trying to ignite a nuclear debate as 'indecent', as nuclear energy has always been a cleavage issue between the PS and EELV, as well as a subject of debate amongst PS members. ${ }^{249}$ Energy Minister Besson also rejected the accusation that the nuclear industry had a large influence in government policy, calling the nuclear lobby an absolute myth. $^{250}$

In response, the EELV criticized the 'soothing' tone of the government and demanded to hold a referendum on the nuclear debate. The PS was a little more muted given its membership's diverging opinion, as they refrained from calling for a moratorium and instead called for a safety assessment of the French nuclear fleet. ${ }^{251}$ The PS also encouraged efforts to learn from Fukushima lessons and move towards an energy mix based on renewables over the next few decades. ${ }^{252}$ Challenging Besson's assertion that there was no nuclear lobby, some of Le Monde's coverage focused on France's history of nuclear energy and a strong elite consensus on the nuclear industry. For the EELV, the nuclear lobby's influence was mainly demonstrated through the prevention of any public debate through its political sponsors' discouragement of parliamentary debate,

\footnotetext{
248 "Japon : une catastrophe nucléaire menace, le bilan humain reste incertain," LeMonde.fr, 15 March 2011, Eureka.cc.

${ }^{249}$ Alexandre Piquard, "Hamon (PS) : "On ne peut pas sortir du nucléaire du jour au lendemain"," LeMonde.fr, 15 March 2011, Eureka.cc.

250 "Papier de verre," LeMonde.fr, 16 March 2011, Eureka.cc.

${ }^{251}$ Piquard, "Hamon (PS)," 15 March 2011; Interview with Stéphane Le Foll conducted by Alexandre Piquard, "PS : "Un référendum sur le nucléaire, c'est précipité"," LeMonde.fr, 15 March 2011, Eureka.cc.

${ }^{252}$ Piquard, "Hamon (PS)," 15 March 2011.
} 
the industry's extensive funding of nuclear scientists who were viewed to be 'in their pocket,' and an active communications campaign that seized control of public discourse. All political parties gave the same reasoning behind this solidarity - energy independence, cost efficiency, and low-carbon impact - and more recently, the importance of the nuclear industry to France's economy. While growing ecological concerns over the past twenty years altered the debate to include more renewables, environmentalists denounced the role of the 'nuclear lobby' in limiting the expansion of renewable energy particularly through the multiple amendments to regulations concerning the installation of wind turbines. They argue that, since 2008, this trend had been formally instituted through the creation of Le Conseil de politique nucléaire (Council of Nuclear Policy), staffed by high-ranking ministers, including the President and Prime Minister. Furthermore, the ruling political elite condemned the slightest criticism of nuclear energy as the UMP had already pre-empted the discussion through categorically stating that there was no room for change; essentially, this was France's path and it was sticking to it. ${ }^{253}$

Ironically, prior to Fukushima, the EELV spoke in support of nuclear energy. ${ }^{254}$ The nuclear issue also played out in some electoral campaigns in France, albeit in terms of avoiding the issue. For example, the Gironde department has four large nuclear power plants, the Blayais plants, which are an important source of regional jobs and economic

\footnotetext{
${ }^{253}$ Samuel Laurent, "Le "lobby nucléaire" existe à gauche comme à droite," LeMonde.fr , 16 March 2011, Eureka.cc.

${ }^{254}$ LeMonde.fr with Agence France-Presse (AFP), "Après Fukushima, l'Autorité de sûreté nucléaire évoque un moratoire sur l'EPR de Flamanville," LeMonde.fr, 1 April 2011, Eureka.cc; LeMonde.fr with Agence France-Presse (AFP), "ASN : l'audit concernera aussi les centrales nucleaires en construction," LeMonde.fr, 2 April 2011, Eureka.cc.
} 
benefits. As a result, candidates in this region's election avoided the nuclear issue almost entirely and the EELV even encouraged their candidates not to dwell on the topic. ${ }^{255}$ Yet the EELV seemed to grow more confident over time to publicly request an independent audit of French nuclear plants by another EU country as opposed to the French nuclear agency. ${ }^{256}$ Areva's CEO Anne Lauvergeon subsequently accused the EELV of trying to replicate the strategy of the German Greens in the 2012 French presidential election by calling on the PS to phase-out nuclear energy. Other newspapers noted this EELV pressure on the PS as well. ${ }^{257}$ Le Figaro in particular focused on EELV and PS negotiations for the 2012 elections. ${ }^{258}$ However, Lauvergeon stated that this phase-out strategy was misplaced as the nuclear industry provided 400,000 direct jobs and accounted for $2 \%$ of France's annual GDP. ${ }^{259}$

Nevertheless, the EELV and an increasing number of PS members continued their call for a phase-out of nuclear energy and the development of alternative energy solutions. ${ }^{260}$ They rejected that neither nuclear energy nor fossil fuels were an affordable

\footnotetext{
${ }^{25 s}$ Claudia Courtois, "La centrale nucléaire s'impose dans la campagne électorale en Gironde," LeMonde.fr, 22 March 2011, Eureka.cc.

236 "Eva Joly demande un audit sur les centrales françaises par un pays tiers," LeMonde.fr, 19 April 2011, Eureka.cc. Factiva.

${ }^{257}$ Rodolphe Geisler, "Nucléaire : les écolos accentuent la pression sur le PS," Le Figaro, 10 June 2011,

${ }^{258}$ Nicolas Barotte, "Socialistes et écologistes se donnent du temps pour négocier," Le Figaro, 3 May 2011, Factiva; Lilian Alemagna, "En quête d'atomes crochus avec le PS," Libération, 3 June 2011, Factiva.

${ }^{259}$ LeMonde.fr with Agence France-Presse (AFP), “Anne Lauvergeon prend la défense du nucléaire français," LeMonde.fr, 15 June 2011, Eureka.cc.

${ }^{260}$ Castelain Christine Meunier and Francis Miller, "Combattre la dette écologique pour s'affranchir des technologies à haut risqué," LeMonde.fr, 31 March 2011, Eureka.cc. Castelain Christine Meunier, a sociologist at the CNRS (EHESS, Cadis), and Francis Miller, a professor at CNAM (Conservatoire National des Arts et Métiers); Nicolas Barotte, "Au PS, la « sortie du nucléaire » en débat," Le Figaro, 8 April 2011, Factiva.
} 
energy solution as the EDF wanted to increase prices more than $30 \%$ over the next five years and Gaz de France increased its prices $5 \%$ on 1 April, despite $€ 4.6$ billion profit in $2010{ }^{261}$ Over the period of study, the official PS position seemed to become that, while France has held nuclear energy as a symbol of national pride since the 1980s, France needed to rethink its policy to prepare for the future. While they did not think a nuclear exit is possible in the short-term, PS members argued that France can begin to redirect its nuclear policy towards energy efficiency and renewable energy. ${ }^{262}$ On 5 April, PS frontrunner Martine Aubry presented 30 proposals as part of the PS's presidential campaign that spoke of a reduction in the share of nuclear power in favor of renewable energy. ${ }^{263}$ The President of the PS group in the National Assembly, Jean-Marc Ayrault, also asked Prime Minister François Fillon to expand the scope of France's safety assessments to include all nuclear facilities and situations including extreme weather, terrorism, and malicious acts. Ayrault also said that the audit committee should include independent external experts. ${ }^{264}$

13 April also brought news that French's premier environmentalist, Nicolas Hulot, was planning to run for president. ${ }^{265}$ While he only threatened to run in the 2007

${ }^{261}$ Matthieu Orphelin, Vice President of the Pays de la Loire Region (EELV), "Pour une tarification écologique et solidaire de l'énergie," LeMonde.fr, 31 March 2011, Eureka.cc.

${ }^{262}$ Caresche Christophe, Jean-Paul Chanteguet, Aurélie Filippetti, MPs (PS), and Géraud Guibert, PS Ecological Division Leader, "Sortons du nucléaire," LeMonde.fr, 8 April 2011, Eureka.cc.

263 "Ausland; Manifest gegen Sarkozy," Süddeutsche Zeitung, 6 April 2011, Factiva.

${ }^{264}$ LeMonde.fr with Agence France-Presse (AFP), "Le PS veut élargir le champ d'investigation de l'Autorité de sûreté nucléaire," LeMonde.fr, 10 April 2011, Eureka.cc.

${ }^{265}$ Alexandre Pouchard, "Nicolas Hulot, du petit écran à la candidature," LeMonde.fr, 13 April 2011, Eureka.cc. http://library.eureka.cc.proxy.library.carleton.ca/WebPages/Search/Result.aspx (20 January 2013). 
presidential election, Hulot often took first place in surveys on the most popular French citizen so he hoped to parlay this popularity into office. ${ }^{266}$ Similarly to Merkel, while Hulot had previously supported nuclear energy, he said that Fukushima proved to him that nuclear energy could not be a solution for the energy needs of the future. ${ }^{267}$ This move may have been an attempt by the EELV to build momentum for the 2012 presidential election. François Hollande, candidate for the PS primary and future French president, also tried to differentiate himself as a Socialist in favour of nuclear energy for energy security and climate protection despite the changing PS position. ${ }^{268}$ This divergence of elite perspectives supports previous sections' arguments that there was the beginning of an anti-nuclear framing in France following the Fukushima disaster, which would begin to come to fruition during the 2012 presidential campaign where the PSEELV coalition emerged as a 'nuclear cautious' alternative to the distinctly pro-nuclear UMP and FN.

Following the German decision to exit nuclear energy, France did begin to have a nuclear debate of sorts but the government remained united while the PS became increasingly divided. ${ }^{269}$ While Prime Minister Fillon emphasized that France respected the German decision, France would not follow its example, as nuclear energy was part of

${ }^{266}$ Stefan Ulrich, "Die grune Eminenz tritt an; Der Fernsehstar und Umweltaktivist Nicolas Hulot will in Frankreich fur die Präsidentschaft kandidieren," Süddeutsche Zeitung, 9 April 2011, Factiva.

${ }^{267}$ LeMonde.fr with Agence France-Presse (AFP), "Nicolas Hulot se rallie à la sortie du nucléaire," LeMonde.fr, 25 April 2011, Eureka.cc; François-Xavier Bourmaud, "Hulot ne veut plus du nucléaire," Le Figaro, 26 April 2011, Factiva.

${ }^{268}$ Samuel Laurent, "Comment Hollande, Aubry, Royal et Montebourg se positionnent sur le nucléaire," LeMonde.fr, 2 June 2011, Eureka.cc.

${ }^{269}$ LeMonde.fr with Agence France-Presse (AFP), "Nicolas Sarkozy égratigne la sortie du nucléaire allemande," 8 June 2011, 
France's energy solution for the future. Besson once again pointed to France's energy independence and its cheap electricity, which he calls $40 \%$ cheaper than the European average and half as expensive as the German average. The UMP Secretary General, JeanFrancois Copé, supported the continuation of nuclear energy as a major industrial power, but Benoit Hamon, PS representative, called for the decision regarding France's nuclear future to be decided through the 2012 presidential election. Hulot, EELV primary candidate, welcomed the German government's decision. Other French critics noted that Germany's decision has repercussions not only for Germany, but also for Europe as a whole. ${ }^{270}$

\subsubsection{A New German Nuclear Consensus}

A Berliner Zeitung article noted that the nuclear consensus arising after the Fukushima disaster had never happened before in Germany. The 1970s and 1980s merely witnessed some construction delays, and even the 2000 "nuclear consensus" to phase-out was a "painstakingly achieved compromise." 271 In contrast, a Die Welt article noted, "In the debate about the German nuclear phase-out, it's not about the 'if' and the 'how' but only the 'how fast'.,"272 In terms of determining the consensus of the German political elite, there are three aspects that need to be considered: inter-party consensus, CDU-FDP coalition consensus, and federal-state consensus.

\footnotetext{
${ }^{270}$ LeMonde.fr with Agence France-Presse (AFP), "Sortie du nucléaire : la décision allemande provoque espoir et inquiétudes en France," LeMonde.fr, 31 May 2011 , Eureka.cc; Thomas Baïetto, "Allemagne : une sortie du nucléaire progressive," LeMonde.fr, 31 May 2011, Eureka.cc.

271 Joachim Wille, “Atomare Zeitenwende," Berliner Zeitung, 18 May 2011, Factiva.

${ }^{272}$ Daniel Wetzel, “Ein teurer Konsens," Die Welt, 16 May 2011, Factiva.
} 
In terms of inter-party consensus immediately after Fukushima, the SPD called for a return to the 2022 nuclear phase-out agreement while the Greens suggested a phaseout by 2017, five years before the eventual CDU-FDP target. They were not pleased with the CDU-FDP's three-month suspension as they wanted an immediate return to the original 2000 phase-out plan, but they did support it. There was also some discontent within Merkel's CDU-FDP coalition about their initial reaction through the three-month moratorium. Former Chancellors, including CDU Chancellor Helmut Kohl, openly criticized Merkel's moratorium and other FDP MPs did as well. ${ }^{273}$ The FDP continued to struggle with the phase-out throughout the period of study. ${ }^{274}$ Some FDP politicians cautioned against the rapid nuclear exit as it could affect Germany's energy security and its energy-intensive industries. ${ }^{275}$ Another interview with a former CSU politician, the Bavarian equivalent of the CDU, warned Merkel against changing course on nuclear policy, as it would result in a lack of credibility for the CDU. ${ }^{276}$ Internal CDU criticism also continued to remain quite high throughout the period of study. ${ }^{277}$

\footnotetext{
273 "Atomwende der Kanzlerin; CDU-Wirtschaftsflugel meutert gegen Merkel," Süddeutsche Zeitung Online, 26 March 2011, Factiva.

${ }^{274}$ Steffen Hebestreit, P. Karl Doemens and Daniela Vates, "Die FDP hadert mit dem Atomausstieg," Berliner Zeitung, 8 June 2011, Factiva.

${ }^{275}$ Ralf Scharnitzky, "Ein bisschen Ausstieg; Wirtschaftsminister Zeil sieht bei einem raschen Abschalten der Atomkraftwerke den Industriestandort gefährdet," Süddeutsche Zeitung, 1 April 2011, Factiva; Peter Blechschmidt, "Kritik aus der zweiten Reihe; In der FDP regt sich Unmut uber die Stilllegung," Süddeutsche Zeitung, 16 March 2011, Factiva.

${ }^{276}$ Oliver Das Gupta, "Atomwende; Ex-CSU-Chef Huber warnt Kanzlerin vor Zickzackkurs," Süddeutsche Zeitung Online, 15 March 2011, Factiva.

${ }^{277}$ Gunther Lachmann, "Deutliche Kritik am System Merkel," Die Welt, 21 May 2011, Factiva; Daniela Vates, "Aussteigen und hoffen - Die Union tut sich schwer mit ihrem neuen Anti-Atom-Kurs," Berliner Zeitung, 3 May 2011, Factiva.
} 
While the CSU government in nuclear-friendly Bavaria initially dismissed Merkel's decision to take the oldest reactors offline for three months as a political maneuver that did not reflect plant safety, most of the other states were fairly supportive of this federal initiative. ${ }^{278}$ However, the later decommissioning of Isar I marked the end of the nuclear age in the traditionally nuclear-friendly Bavaria. ${ }^{279}$ Horst Seehofer, head of the CSU, later shifted his party's course to advocate for a nuclear exit and silenced his internal party critics on this point, leading to a unified CDU/CSU official position on nuclear energy. ${ }^{280}$ There was news that North Rhine-Westphalia wanted to bring in a motion to lead to the withdrawal of the life extension of nuclear power plants as well as the shutdown of old nuclear power plants; a proposal that other SPD-led governments were likely to support. ${ }^{281}$ Furthermore, Baden-Württemberg Premier Stefan Mappus announced that Neckarwestheim 1 was to be permanently shut down, perhaps as a lastminute election move. ${ }^{282}$

\footnotetext{
278 “Atomkraft spaltet Parteien; Stilllegung von Isar 1: CSU und SPD beziehen gegensătzliche Positionen," Süddeutsche Zeitung, 16 March 2011, Factiva.

${ }^{279}$ Christian Sebald and Mike Szymanski, "Christliche Salto-Union; Die CSU wirft uber Nacht ihre Atompolitik uber Bord: Isar 1 wird abgeschaltet - kein Problem, sagt der Betreiber Eon, es gebe genugend andere Kraftwerke," Süddeutsche Zeitung, 16 March 2011, Factiva.

${ }^{280}$ Mike Szymanski, "Seehofer legt den Schalter um; Mit aller Kraft zwingt der CSU-Vorsitzende seine Partei auf den neuen Atomkurs - die Kritiker werden abgekanzelt," Süddeutsche Zeitung, 30 March 2011, Factiva; “ „Japan verăndert alles"; Umweltminister Markus Sðder plädiert nach dem Atomunfall in Fukushima für einen schnelleren Umstieg auf Öko-Energie," Süddeutsche Zeitung, 14 March 2011, Factiva; "Sø̋der: Schneller zur erneuerbaren Energie," Süddeutsche Zeitung, 14 March 2011, Factiva.

${ }^{281}$ Susanne Holl, "Angriff in aller Pietăt; SPD und Grune attackieren den Atomkurs der Regierung wegen der vielen Opfer in Japan aber nicht allzu harsch," Süddeutsche Zeitung, 15 March 2011, Factiva.

${ }^{282}$ Michael Bauchmuller, "Sieben deutsche Reaktoren werden abgeschaltet; Bund und Lănder legen alte Atomkraftwerke vorubergehend still / Neckarwestheim 1 geht endgultig vom Netz," Süddeutsche Zeitung, 16 March 2011, Factiva.
} 
In terms of the elite consensus leading up to the key state elections and the nuclear phase-out, the Greens were particularly active in trying to differentiate themselves from the growing anti-nuclear elite consensus as the 'original' anti-nuclear party. The Greens tried to direct public discontent into action on Saturday, $26 \mathrm{March}^{283}$ According to organizers, more than 200,000 protesters marched throughout Germany, including 100,000 in Berlin. ${ }^{284}$ They also organized lecture series and other events on nuclear energy, particularly to commemorate the $25^{\text {th }}$ anniversary of Chernobyl. ${ }^{285}$ This benefited the Greens, as the Greens in Bavaria reported a sharp increase in membership (from about three new members to 25 or 30 members on a daily basis). In contrast, the Bavarian CSU and FDP reported declining membership over the same period. ${ }^{286}$ SPD campaigners were equally thrilled in the change of fortunes of the CDU and FDP. ${ }^{287}$ However, in other parts of the country, both the CDU and SPD's membership declined. ${ }^{288}$ Curiously, some articles noted that Merkel may have been looking for a new coalition partner in the Greens and that this was part of the reason for the CDU's shift in nuclear

\footnotetext{
${ }^{283}$ Frédéric Lemaître, "Allemagne : mobilisation anti-nucléaire avant un scrutin clé pour Merkel," LeMonde.fr, 26 March 2011, Eureka.cc.

284 "L'Allemagne anti-nucléaire Samedi," LeMonde.fr , 28 March 2011, Eureka.cc; "Protest gegen Atomkraft; "Fukushima mahnt"," Süddeutsche Zeitung Online, 26 March 2011, Factiva.

285 “Garching," Süddeutsche Zeitung, 19 March 2011, Factiva.

${ }^{286}$ Stefan Mayr, "Atomdebatte beschert Grunen großen Zulauf; Die Partei registriert tăglich 25 bis 30 neue Mitglieder, auch der schwäbische JU-Bezirkschef wechselt die Seiten," Süddeutsche Zeitung, 24 March 2011, Factiva.

${ }^{287}$ Michael König, "Baden-Württemberg im Wahlkampf; Manöver auf den letzten Metern," Süddeutsche Zeitung Online, 26 March 2011, Factiva.

288 "Politische Marken im Wandel der Zeiten - Politische Landschaft - Union Und SPD Verlieren Massiv Mitglieder Und Ihren Status Als Organisationen Für Alle Schichten. Alle Umfragen Sehen Die Grunen Im Aufschwung, Die Wollen Aber Nicht Volks- Sondern Lieber Gestaltungspartei Sein." Berliner Zeitung, 10 June 2011, Factiva.
} 
policy. ${ }^{289}$ However, CSU General Secretary Alexander Dobrindt denied this and insisted it would be a grave error. ${ }^{290}$ This speculation certainly added to internal CDU-FDP discontent about the coalition's phase-out decision.

Federal-state consensus appeared strong on the phase-out and the process appeared to be amicable. It was agreed early on that no further action would be taken to accelerate the development of renewable energies until a meeting on 15 April between Merkel and all state leaders. ${ }^{291}$ Federal and state governments also agreed to speed up their advisory period so that new legislation could be voted on by mid-June to phase-out nuclear energy. ${ }^{292}$ Prior to the government making the nuclear exit decision, environment ministers from federal and state governments agreed that the seven oldest nuclear plants would not go back online. ${ }^{293}$ The Greens were actually in a difficult political position after the nuclear exit was announced. If they did not support this proposal, they provided the CDU and FDP with ammunition for their anti-Green campaign. Yet their environmental supporters already thought the 2000 SPD-Green phase-out was not rapid enough. ${ }^{294}$ Merkel further challenged the opposition, especially the Green Party, not to

${ }^{289}$ Torsten Krauel, "Die CDU und ihre Grunen," Die Welt, 10 June 2011, Factiva. Patrick Saint-Paul, "Le flirt de Merkel avec les Verts agace ses alliés libéraux," Le Figaro, 16 June 2011, Factiva.

${ }^{290}$ Thomas Vitzthum, "Mit den Grunen? Niemals!" Die Welt, 12 April 2011, Factiva.

291 "Krisengipfel in Berlin; Töpfer wird oberster Atom-Weiser," Süddeutsche Zeitung Online, 22 March 2011, Factiva.

${ }^{292}$ Nico Fried, "Atomausstieg im Schnellverfahren; Merkel und die Ministerprăsidenten verkurzen Fristen, um Gesetz bereits im Juni verabschieden zu können," Süddeutsche Zeitung, 16 April 2011, Factiva.

293 "Debatte um Atomausstieg; Umweltminister wollen alte Meiler endgultig stilllegen," Süddeutsche Zeitung Online, 27 May 2011, Factiva.

${ }^{294}$ Michael Bauchmüller and Susanne Höll, "Dafur ist genauso schwer wie dagegen; Rot-Grün wollte das Ende der Kernkraft selbst schon lange durchsetzen - deshalb zogert die skeptische Opposition jetzt damit, einen Konfrontationskurs einzuschlagen," Süddeutsche Zeitung, 31 May 2011, Factiva; Karl 
oppose measures to increase Germany's share of renewable energy such as wind farm construction or the modernization of the power grid. ${ }^{295}$

From this summary, it can be seen that every major German political party was moving to an anti-nuclear platform as part of their official approach. However, this official party policy did not reflect the strong divisions that remained within the CDUFDP coalition as well as their individual parties throughout this paper's period of study. In contrast, while state governments were initially divided about the three-month moratorium, most state governments, including the most stalwart nuclear proponent state of Bavaria, would reach a fairly strong consensus with the CDU federal government by the end of the period of study. In short, it could be said that Fukushima prompted the emergence of an official elite consensus in Germany as well as an official nuclear policy change.

\subsubsection{Changing Perspectives of the French and German Political Elite}

Inspired by Kolb's quantitative analysis, this paper suggested that the more political elites are divided on the issue of nuclear energy, the greater the impact of antinuclear sentiment in achieving a policy change. As discussed, the initial Fukushima response was broad French support of the nuclear industry while the German SPDGreens called for a return to the nuclear phase-out and the CDU-FDP tried to call for calm while the safety of plants was being assessed during the three-month moratorium. However, the Fukushima crisis also prompted a reversal in elite consensus trends.

Doemens, "Grune wollen fur Merkels Atomgesetz stimmen - Der Leitantrag zum grunen Sonderparteitag löst Kritik an der Basis und bei Umweltverbånden aus," Berliner Zeitung, 18 June 201 1, Factiva.

${ }^{295}$ LeMonde.fr with Agence France-Presse (AFP), "Berlin va accélérer le passage aux énergies renouvelables,” LeMonde.fr, 18 March 2011, Eureka.cc. 
From the beginning of the Fukushima disaster to the announcement of the German exit, the political consensus in both countries began to change. This can be seen through the example of the titular Fessenheim. While almost fifty German municipalities advocated the closing of Fessenheim, only three French mayors did so at the beginning of the crisis. ${ }^{296}$ Perhaps as a sign of growing skepticism and change in French political culture, Haut-Rhin requested postponing authorization of Fessenheim's ten-year extension (located on its territory) on 15 April until the safety assessment results were released. ${ }^{297}$ More strongly, Strasbourg's city council formally requested the closure of Fessenheim, becoming the first Alsatian community to adopt such a motion. ${ }^{298}$ From such shifts, it can be seen that, while an anti-nuclear framing was not present in France to take initial advantage of the Fukushima crisis, this framing did begin to emerge in France as a result of the disaster to take advantage of future political opportunities such as the 2012 presidential election.

In summary, the initially strong French consensus contained anti-nuclear sentiment, while a fractured German political elite meant that public hostility to nuclear energy could prompt the pro-nuclear CDU-FDP coalition to institute a nuclear phase-out. Ironically, such an anti-nuclear consensus exists in Germany now that pro-nuclear sentiment would have difficulty convincing Germany to reinvest in nuclear energy.

\footnotetext{
${ }^{296}$ LeMonde.fr with Agence France-Presse (AFP), “Après Fukushima, l'Autorité de sûreté nucléaire évoque un moratoire," 1 April 2011; LeMonde.fr with Agence France-Presse (AFP), "ASN : l'audit concernera aussi les centrales nucléaires en construction," LeMonde.fr, 2 April 2011, Eureka.cc.

${ }^{297}$ LeMonde.fr with Reuters, "En Alsace, le sort de la centrale de Fessenheim mobilise les élus," LeMonde.fr, 16 April 2011, Eureka.cc.

${ }^{298}$ LeMonde.fr with Agence France-Presse (AFP), "Le conseil municipal de Strasbourg pour la fermeture de la centrale de Fessenheim," LeMonde.fr, 13 April 2011, Eureka.cc.
} 
Furthermore, while not part of the survey period, this role of elite consensus in encouraging policy change continued to hold true in the French case as the growing unease of the PS party with nuclear energy prompted a coalition deal with the EELV before the 2012 parliamentary and presidential elections. This PS-EELV coalition promised to reduce the share of nuclear energy in France's electricity mix to $50 \%$ by 2025, amounting to the closure of 24 nuclear reactors. ${ }^{299}$ The titular Fessenheim was the first to be identified for decommissioning upon the electoral success of the coalition.

While not directly related to this paper's argument, French and German commentary on the other country's reaction to the Fukushima disaster does provide some insight into how the public and political elite saw their own country's reaction as well as contextualizes each country's reaction. This commentary will be explored now.

\subsection{Fukushima Divides: France, Germany, and European Reactions}

This section will discuss France's perceptions of the German anti-nuclear decision, Germany's perception of the French nuclear debate, and their interaction within the context of EU dialogue. Interestingly, while both countries' media commented on the other's Fukushima reaction, more articles were focused on the German anti-nuclear debate in the French media coverage as opposed to the other way around, and only French political figures commented extensively on the German reaction with no prominent example of German politicians commenting on France. This is perhaps to be expected, as the German policy change was far more dramatic than the French status quo.

\footnotetext{
${ }^{299}$ Angelique Chrisafis, "Nuclear row splits French government," The Guardian, 28 August 2012. Retrieved from http://www.guardian.co.uk/world/2012/aug/28/nuclear-row-splits-french-government on 12 March 2013.
} 


\subsubsection{French Media and Political Commentary on Germany's Fukushima}

\section{Response}

One Süddeutsche Zeitung article provided a French journalist's perspective on the German nuclear debate. The article noted that the French never experienced the antinuclear movement the way that Germany did and instead focused their dissent elsewhere. She chuckled when she considered her naiveté in accepting the French government's assertion that Chernobyl's radioactive cloud would simply stop at the French border, and remembers how the French made fun of the German 'Angst' and 'culture of disaster,' which in the eighties seemed to have its new calling 40 years after the war - the 'resistance to the atom'. She thought that Germans must think the French to be terribly foolish, blinded by the illusionary infallibility of modern technology to try to compensate for their military loss half a century earlier with notions of energy independence. While the French can be brought to the streets to advocate for their pensions, nuclear energy had minimal mobilization. ${ }^{300}$

The French government's response to the German nuclear phase-out was extensively explored in the French case study, but to reiterate, French government officials were quite vocal in their condemnation of the German decision and emphasized its environmental and price impacts. In response to the German nuclear exit, Areva's CEO, Anne Lauvergeon, condemned the German decision to close its last nuclear reactor in 2022 as purely political as there was no referendum or formal assessments of public

${ }^{300}$ Hugues, "Die Strahlung, die am Rhein anhielt," 5 April 2011. 
opinion. ${ }^{301}$ This backlash could have been due to the fact that Areva lost more than $4 \%$ on the 30 May Paris Stock Exchange likely in response to Germany's announcement. ${ }^{302}$ While France presented Germany's exit as both electioneering and hypocritical, according to some articles, these two arguments do not stand up to rational analysis. Bouzou argues that, while nuclear energy seemingly provides cheap electricity, the public is not presented with the full cost of a nuclear accident as, while the probability of such an accident may be low, its widespread effects over such a long period of time makes the cost very high. ${ }^{303}$ Laponche explains that, in 2008 , Germany's electricity consumption per capita was $6,000 \mathrm{kWh}$ per year, while France's was significantly more at 7,000 kWh. While German industry is more energy-intensive than French industry, residential consumption per capita in Germany remains less than $20 \%$ to $30 \%$ of France's consumption. Germany also has more solar energy capacity despite France's greater solar potential. ${ }^{304} \mathrm{He}$ further debunks the myth that Germany relies mainly on oil and electricity imports, as France imports more electricity from Germany than Germany does from France (during the period of study). Therefore, France imports electricity, the production of which generates $\mathrm{CO}_{2}$ emissions, but these emissions are not counted in France. France also actually consumes a little more oil than Germany. Finally, Laponche

\footnotetext{
${ }^{301}$ LeMonde.fr with Agence France-Presse (AFP), "Pour Anne Lauvergeon, l'arrêt du nucléaire allemand est "politique"," LeMonde.fr, 30 May 2011, Eureka.cc.

${ }^{302}$ LeMonde.fr with Agence France-Presse (AFP), "Sortie du nucléaire : la décision allemande provoque espoir et inquiétudes en France," LeMonde.fr, 31 May 2011, Eureka.cc; Baïetto, "Allemagne : une sortie du nucléaire progressive," 31 May 2011, Eureka.cc.

${ }^{303}$ Bouzou, "Comme en Allemagne," 16 June 2011.

${ }^{304}$ Chat with Bernard Laponche moderated by Grégoire Allix et Emmanuelle Chevallereau, "Tous les prétextes ont été bons pour limiter le développement des énergies renouvelables", LeMonde.fr, 6 April 2011, Eureka.cc.
} 
argued that it seemed that Germany is on a trajectory towards greater energy efficiency and renewable energy as the share of renewables in electricity production in Germany was $4 \%$ in $1991,18 \%$ in 2011 , and the 2020 target is $35 \%$. This target is larger than the current share of nuclear energy production of $30 \%$. In contrast, $11 \%$ of France's electricity generation came from renewable sources in 1991, but this proportion was only $14 \%$ in $2011 .^{305}$

Also interesting was the degree to which Le Figaro followed German politics, including internal party relations and broader federal-state relations. ${ }^{306}$ The newspaper also covered the German regional elections quite extensively. ${ }^{307}$ However, much of Le Figaro's coverage focused on Germany's phase-out plans as well as the Franco-German relationship. ${ }^{308}$ One article lamented the lack of Franco-German dialogue as, while the Elysée Treaty of 1963 provides for at least two annual bilateral executive meetings, Sarkozy and Merkel had not met in seven months. It went on to argue that this bilateral meeting would have defused tensions caused by the German nuclear exit without French consultation. $^{309}$ Why Germany should have consulted France is unclear. However, one

${ }^{305}$ Chat with Bernard Laponche, "Tous les prétextes ont êté bons," 6 April 2011.

${ }^{306}$ Patrick Saint-Paul, "Nucléaire : les Lănder font de la résistance," Le Figaro, 2 June 2011, Factiva; Patrick Saint-Paul, "Énergie nucléaire : le virage de Merkel irrite ses allies," Le Figaro, 5 May 2011, Factiva; Patrick Saint-Paul, "L'Allemagne se convertit à l'écologie," Le Figaro, 20 April 2011, Factiva; Patrick Saint-Paul, "Les Verts en tête des sondages en Allemagne," Le Figaro, 8 April 2011, Factiva.

${ }^{307}$ Patrick Saint-Paul, "En Allemagne, la vague verte balaye les conservateurs," Le Figaro, 24 May 2011, Factiva; Patrick Saint-Paul, "Les Verts infligent un camouflet à Angela Merkel," Le Figaro, 28 March 2011, Factiva.

${ }^{308}$ Anne-Marie Le Gloannec, "L'Allemagne voit plus loin que l'Europe," Le Figaro, 25 March 2011, Factiva.

${ }^{309}$ Patrick Saint-Paul, "L'indispensable proximité franco-allemande," Le Figaro, 18 June 2011, Factiva; Alain-Gérard Slama, "Le cout de la non-Europe," Le Figaro, 8 June 2011, Factiva. 
article stated that the German nuclear choices are their own and, since the first oil crisis, energy policy has never been a strong field of Franco-German cooperation anyway so it should not matter for the relationship. ${ }^{310}$ Le Figaro's coverage also focused on concern about the impact of the German exit on the European energy supply. ${ }^{311}$

When taken in combination with the French government's reaction to the German nuclear exit discussed earlier in the paper, it can be seen that the German decision prompted a great deal of discussion within the public and political spheres. For the public, it seemed like the German decision represented an example to emulate (albeit over a longer term in order to preserve energy security) while the political discussion generally aimed at disarming this example by focusing on the impacts of the decision on energy prices and security.

\subsubsection{German Media and Political Commentary on France's Continued Nuclear}

\section{Path}

The German media did not comment as extensively on the French reaction as the French media did on the German reaction. For most German commentators, the most worrying part of the French nuclear program was that two of its most controversial reactors were located right on the German border. ${ }^{312}$ These problems were compounded by the fact that France shares many parallels with Japan, notably a lack of transparency

\footnotetext{
${ }^{310}$ Henrik Uterwedde, "Allemagne : le pari de l'après-nucléaire," Le Figaro, 3 June 2011, Factiva; Patrick Saint-Paul, "La « neutralité » allemande irrite les allies," Le Figaro, 14 April 2011, Factiva.

${ }^{311}$ Frédéric De Monicault, "La fin du nucléaire en Allemagne dérègle le marché européen de l'électricité," Le Figaro, 31 May 2011, Factiva; Fabrice Nodé-Langlois, "Nucléaire : Merkel avance à 2015 les prochaines fermetures," Le Figaro, 7 June 2011, Factiva.

${ }^{312}$ Michael Kläsgen, "Japan ist ganz nah; Auch Frankreich verharmlost die Gefahren," Süddeutsche Zeitung, 16 March 2011 , Factiva.
} 
about the effectiveness of security measures, the risks involved in nuclear energy, and the extent of incidents. ${ }^{313}$ One article also suggested that, as the industry is partially supported by the government, the industry can boast of transparency while covering up or minimizing problems. ${ }^{314}$ Adding to the problem, according to this article, is that the French media was either powerless or submissive, resulting in the French public not being well-informed. ${ }^{315}$ This is perhaps unfair as other journalists' assessments were that all major French newspapers provided major coverage on the Fukushima disaster with readers fueling this interest. ${ }^{316}$ The article also demanded that Germany have a right to information on border reactors, particularly Fessenheim, which is one of the oldest and most controversial.

In commenting on reasons behind France's decision, one German journalist indicated a cultural identity explanation that France's position is a result of feeling confident that man can tame nature while another defends 'German Angst' as a more accurate understanding of the risks involved. ${ }^{317}$ However, there was German recognition that the Germans were currently more fearful than the Japanese. ${ }^{318}$

${ }^{313}$ Klasgen, "Japan ist ganz nah," 16 March 2011.

${ }^{314}$ Ibid., 16 March 2011.

${ }^{315}$ Ibid., 16 March 2011.

${ }^{316}$ Hugues, "Die Strahlung, die am Rhein anhielt," 5 April 2011.

${ }^{317}$ Stefan Ulrich, "Wankendes Dogma; Kernkraftwerke waren bisher Frankreichs ganzer Stolz - jetzt regen sich emste Zweifel an der Nuklearwirtschaft," Süddeutsche Zeitung, 18 March 2011, Factiva; "Außenansicht; Politik in Zeiten der Furcht; Atomkrise und Libyen-Krieg: Wieder einmal spotten Nachbarn in Europa uber die „German Angst“ - zu Unrecht," Süddeutsche Zeitung, 31 March 2011, Factiva.

${ }^{318}$ Arno Widmann, "Fürchtet euch! - Die "German Angst" ist wieder da. Sie mag ein lächerliches Gefuhl sein, doch selten war sie nutzlicher als heute," Berliner Zeitung, 19 March 2011, Factiva. 
French and German perceptions of the other's nuclear policy reaction after Fukushima were perhaps personified in the joint press conference between Sarkozy and Merkel on 17 June in Berlin. At this press conference, Sarkozy reiterated that France respected Germany's position but that France would continue its nuclear program with the highest of safety standards. However, he acknowledged that there was no safety without transparency and that Germany should expect transparency about Fessenheim and any other nuclear power plant. ${ }^{319}$ This statement captured the French commitment to the present course while also referencing the themes in German media coverage concerning France's lack of transparency on the nuclear issue. As per the trend in the German media commentary, Merkel made no comment about France's nuclear stance.

\subsubsection{Fukushima Reactions in the EU Theatre}

French and German direct commentary on each other is however supplemented by their participation in a wider European reaction to the Fukushima disaster. On 15 March, the EU announced that it wanted to check the safety of Europe's nuclear plants immediately. ${ }^{320}$ The European Commission however is only partially responsible for nuclear power plants as, while a 2009 EU directive establishes minimum safety requirements, the majority of responsibility remains with national governments. ${ }^{321}$ Upon assuming the EU Energy Commissioner position a year prior, Günther Oettinger pledged

\footnotetext{
${ }^{319}$ Visit to Germany - Statements by Nicolas Sarkozy, President of the Republic, at his joint press conference with Angela Merkel, Chancellor of Germany (excerpts), 17 June 2011. Retrieved from http://www.ambafrance-uk.org/President-Sarkozy-s-press, 19170 on 18 March 2013.

${ }^{320}$ Cerstin Gammelin and Michael Frank, "Stresstest fur Europas Meiler; Brussel will die Sicherheit der Atomkraftwerke uberprufen lassen / Österreich fuhlt sich besonders bedroht," Süddeutsche Zeitung , 15 March 2011. Factiva.

${ }^{32 !}$ Gammelin and Frank, "Stresstest fur Europas Meiler," 15 March 2011.
} 
to make energy policymaking more 'European.' Oettinger also warned that energy costs would be considerably more expensive in the coming years and that there was a risk of 'energy poverty' in Europe. ${ }^{322}$ However, his policy tools were few as the common European policy framework operates on the principle that member states agree on a common goal, but each state has the flexibility to choose how they accomplish it; this framework resulted in a situation in which France produces four-fifths of its electricity with nuclear power, while Germany is now shifting away from nuclear energy. ${ }^{323}$ Problems in achieving a European response lay not only in trying to find consensus between member states but also in the legal framework found in the Euratom Treaty. Some media coverage advocated the reform of this treaty to establish mandatory safety standards, but realistically acknowledged a common approach to nuclear policy in Europe will not exist in the long run. Instead, they suggested Europe should focus on a common understanding and regulation of risk as they represent a community that shares the risk. ${ }^{324}$

On 23 May, the director of the International Energy Agency, Nobuo Tanaka, criticized Merkel's nuclear withdrawal as threatening Europe's overall nuclear security. ${ }^{325}$ On 24 March, heads of state met in Brussels to address the issue of European nuclear safety, as requested by German Chancellor Angela Merkel and Austrian leader

\footnotetext{
${ }^{322}$ Michael Konig, “Atomausstieg: Strompreise; Kampf den Horrorszenarien," Süddeutsche Zeitung Online, 26 May 2011, Factiva.

${ }^{323}$ Cerstin Gammelin, "Europa; Gespaltene Gemeinschaft; Energiekommissar Gunther Oettinger hat große Ziele, die Umsetzung aber bereitet große Probleme," Süddeutsche Zeitung, 13 April 2011, Factiva.

324 "Außenansicht; Deutschlands Alleingang; Nach Fukushima: Ein europaweiter Atomausstieg bleibt eine politische Illusion," Süddeutsche Zeitung, 17 May 2011, Factiva.

325 "IEA warns Merkel on nuclear decision," United Press International. Retrieved from http://www.upi.com/Business News/Energy-Resources/2011/05/23/1EA-warns-Merkel-on-nucleardecision/UPI-11251306169748/ on 14 January 2013; "Atomausstieg; Energieagentur warnt vor deutschem Alleingang," Süddeutsche Zeitung Online, 23 May 2011, Factiva.
} 
Werner Faymann. ${ }^{326}$ However, Sarkozy was suspicious of their intentions. The French government was already on guard from the 'Apocalypse' comments made by Commissioner Oettinger at the height of the Fukushima disaster. Oettinger then requested stress tests on European power plants, which was echoed by Merkel and Faymann. France had already committed to safety assessments of its plants but planned to defend the right of national safety authorities to conduct these assessments. ${ }^{327} \mathrm{EU}$ countries therefore disagreed on a common course of action with some of the EU's 27 energy ministers criticizing Germany's direction as well as Oettinger's 'meddling.' They also argued that it was pointless to ask for nuclear stress tests if there was no consensus on safety criteria. ${ }^{328}$ On $25 \mathrm{March}$, the 27 leaders agreed to examine and, if necessary, improve their plants' safety. Merkel and Faymann's full plan was not accepted, but they did receive the safety assessments with standardized criteria that they requested. The UK wanted these assessments to be 'recommended' and not mandatory. Other leaders were divided on the consequences of the tests, but Merkel and Sarkozy both promised that any plants that failed would be closed. ${ }^{329}$

One of the largest public upsets in early May was the revelation that safety tests for European nuclear power plants would be significantly weaker than previously

\footnotetext{
${ }^{326}$ Stefanie Bolzen, "Europa bei AKW-Stresstests gespalten," Die Welt, 20 May 2011, Factiva. Faymann was concerned with aging reactors located in neighbouring countries as Austria had abandoned nuclear energy in 1970s.

${ }^{327}$ Philippe Ricard, "L'UE débat de la sûreté de ses centrales nucléaires," LeMonde.fr, 25 March 2011, Eureka.cc.

${ }^{328}$ Cerstin Gammelin, “Atompolitik spaltet Europa; EU-Lånder können sich nicht auf gemeinsame Sicherheitsprufung aller Meiler einigen,” Süddeutsche Zeitung , 22 March 2011, Factiva.

${ }^{329}$ Cerstin Gammelin, "Stresstests ohne Stress; Überprufung der Atommeiler in der EU bleibt freiwillig," Süddeutsche Zeitung , 26 March 2011, Factiva.
} 
announced. An association of nuclear power operators proposed that nuclear reactors only be checked to see if they can withstand natural disasters and severe temperature changes. ${ }^{330}$ Operators even suggested that they simply prepare a written report to the European Commission, without the presence of independent European experts during the assessments. ${ }^{331}$ Merkel's government was rumoured to be significantly disgruntled by this dilution, particularly that no uniform safety criteria would be set as risks do not stop at borders and standards for German plants should be used for neighbouring facilities. ${ }^{332}$ In contrast, France and Britain were apparently leading the calls for relaxed criteria for these tests. ${ }^{333}$ The inclusion of testing resistance to terrorism attacks was particularly contentious as French Prime Minister Fillon argued that integrating an attack scenario would be too dangerous considering the EU's obligation to make the findings public. ${ }^{334}$

On 24 May, EU Members came to an agreement on the parameters of the nuclear stress tests that were endorsed by Commissioner Oettinger. It was apparently a compromise that includes testing on natural disasters as well as the consequences of any

\footnotetext{
${ }^{330}$ Cerstin Gammelin, "EU verzichtet auf strenge Reaktor-Tests; Mbgliche Folgen von Flugzeugabstürzen oder von menschlichem Versagen sollen nicht untersucht werden," Süddeutsche Zeitung, 4 May 2011, Factiva.

${ }^{331}$ LeMonde.fr with Agence France-Presse (AFP), "Centrales nucléaires : des tests de sécurité moins ambitieux," LeMonde.fr , 4 May 2011, Eureka.cc.

332 "EU verzichtet auf strenge Reaktor-Tests; Berlin empört sich uber Brussel," Süddeutsche Zeitung Online, 4 May 2011, Factiva.

${ }^{333}$ LeMonde.fr with Agence France-Presse (AFP), "Centrales nucléaires,” 4 May 2011.

${ }^{334}$ Jean-Pierre Stroobants, "Désaccord européen sur les stress tests nucléaires," LeMonde.fr , 12 May 2013, Eureka.cc.
} 
natural or manmade accidents, but did not deal with security against terrorism. ${ }^{335}$ More controversial was the Swiss suggestion on 7 June at an international conference in France that data on reactor safety should be exchanged between countries (i.e. Germany could see French data and vice versa). While Germany supported the proposal, they wanted to consult operators before proceeding. ${ }^{336}$

In terms of France and Germany's participation in other broader Fukushima discussions, an official G8 Summit was held in Deauville, France, on 26 and 27 May. In anticipation of this summit, approximately 4,000 protesters gathered in Le Havre on 21 May with anti-nuclear and environmental groups being some of the 35 NGOs present. ${ }^{337}$ Le Havre was chosen as an alternative gathering place for those denied access to the summit, but the large majority of activists were French with little international presence. The agenda for this summit had already been established months prior to the Fukushima disaster, but there was a working lunch on the situation in Japan on 26 May along with a session in the afternoon on climate change. However, while nuclear safety was given some lip service, the majority of the lunch session's focus was on aiding Japan to recover economically. The overall summit's focus was on supporting freedom and democracy in relation to the Arab Spring.

Upon the announcement of the German nuclear exit on 30 May, Europe and the world were divided. British Energy Secretary Chris Huhne said Britain would stick to its

\footnotetext{
${ }^{335}$ LeMonde.fr with Agence France-Presse (AFP), "L'UE parvient à un accord sur les "stress test" des centrales nucléaires," LeMonde.fr, 25 May 2011, Eureka.cc.

${ }^{336}$ Markus Balser, Michael Kläsgen and Gunnar Herrmann, "Angst um die Rendite; Die Atomkonzerne beklagen sich bei der Bundesregierung," Süddeutsche Zeitung, 8 June 2011, Factiva.). Factiva.

${ }^{337}$ Elodie Auffray, "Les altermondialistes en petite délégation au Havre," Libération, 23 May 2011,
} 
nuclear future, and criticized Berlin for its approach. ${ }^{338}$ Similarly, the post-communist countries continued to advocate the use of nuclear energy so Eastern Europe also disregarded Fukushima. ${ }^{339}$ The Scandinavians continued to build new plants despite Fukushima and it was not an issue in the Finnish election campaign in April. ${ }^{340}$ On the other hand, China decided to put its numerous nuclear power plant projects on hold. ${ }^{341}$ Italy decided to postpone its re-entry into nuclear energy after Fukushima, holding a referendum on the issue. ${ }^{342}$ Turkey ironically wanted to build nuclear power plants through business with TEPCO, whose representatives were in Ankara at the time of the Fukushima disaster. ${ }^{343}$ India also desired to build new nuclear power plants with foreign assistance. ${ }^{344}$ In short, there was no universal Fukushima reaction.

\subsubsection{Contextualizing Fukushima Reactions}

From these reactions, it can be seen that there was not a European consensus on nuclear energy and France was one of many countries that criticized Germany's approach. This makes Germany's nuclear exit even more striking and adds some weight

${ }^{338}$ Andreas Oldag, “Ärger mit Angela; Großbritanniens Energieminister Chris Huhne verteidigt seine Pro-Atom-Linie - und will sich weder von Berlin noch von Brüssel etwas vorschreiben lassen,"

Süddeutsche Zeitung, 18 March 2011, Factiva.

${ }^{339}$ Klaus Brill, "Weiterbauen! Osteuropa setzt auf Atomenergie - der Super-GAU in Fukushima hat daran wenig geăndert," Süddeutsche Zeitung, 17 March 2011, Factiva.

${ }^{340}$ Gunnar Herrmann, "Sorglose Skandinavier; Nordeuropăer bauen trotz Ungluck in Japan neue Meiler," Süddeutsche Zeitung, 15 March 2011, Factiva.

341 "Peking bremst," Süddeutsche Zeitung, 17 March 2011, Factiva.

${ }^{342}$ Marcus Heithecker and Tina Kaiser, "Nur Italien teilt die deutschen Ängste," Die Welt, 27 May 2011, Factiva; Eric Jozsef, “L'Italie ne veut pas reprendre de l'atome,” Libération, 14 June 2011, Factiva.

${ }^{343}$ Kai Strittmatter, "Es kommt noch besser; Die Turkei will sich Atomkraftwerke bauen lassen. Von den Japanem. Ausgerechnet die Firma Tepco ist gerade in Ankara, um das Geschăft rund zu machen," Süddeutsche Zeitung , 17 March 2011, Factiva.

344 Tobias Matern, "Fester Glaube; Indiens Energiehunger ist groß, das Land will mit ausländischer Hilfe etliche neue Kernkraftwerke bauen," Süddeutsche Zeitung, 18 March 2011, Factiva. 
to this paper's argument concerning the necessity of the presence of both anti-nuclear framing and political opportunities to achieve policy change. Europe was in the midst of a nuclear renaissance at the time of the Fukushima disaster, making ready anti-nuclear frames unlikely. Furthermore, the extent of the German electoral opportunities during 2011 made the potential expression of this framing unparalleled in Europe at the time. While this section does not directly relate to this paper's argument, it is useful in providing a glimpse of the broader European reaction to the Fukushima nuclear disaster and contextualizing France and Germany's individual reactions. 


\section{Chapter: Explaining Diverging Reactions to the Fukushima Disaster}

From this limited thematic media analysis, this paper has argued that there must be both a framing of the issue as well as a political opportunity for the issue to become manifest in policy. This paper has also supported previous literature's conclusions about the importance of historical experience, political opportunities, public opinion, and elite consensus in producing political change on nuclear policy. Germany's previous history with anti-nuclear mobilizations provided a ready framing of the nuclear energy issue that was able to influence change in response to the Fukushima political opportunity due to the precarious electoral position of the coalition between the Christian Democrats (CDU) and the Free Democratic Party (FDP). In France, the historical eradication of the French anti-nuclear movement around 1981 meant that a framing of the issue was not ready to take advantage of such a major political opportunity and a comparable electoral opportunity was more than a year away as France's centralized structure meant that only presidential elections would have presented such an opportunity.

Yet the Fukushima disaster did have an impact on France's nuclear direction through inspiring a new anti-nuclear framing. When considering the greater discussion in the French media of concerns about the transparency and democracy aspects of nuclear energy as well as the relationship between government and industry, it can be seen that the French public and media was trying to articulate problems and provide solutions, which are the first two tasks in the framing process. This is significant, as the framing was taking place at a time where the French political elite held a strong pro-nuclear consensus. France's extensive investments in its civilian nuclear program and the perpetual storage costs of nuclear waste meant that it was difficult for any French 
government with a chance at governing to commit to a change in course. Furthermore, France's 'closed' institutional structure meant that the government could continue to dismiss criticism of its nuclear program. It tried to use well-established packages such as 'energy independence' and 'progress' as well as new 'low-carbon alternative' and 'cheap electricity' packages in defence of its nuclear program but the French public's skepticism towards nuclear energy continued to grow, which was reflected in the new anti-nuclear framing process. This framing may have had an effect in producing a Parti socialiste (PS) coalition deal with the Écologie - Les Verts (EELV) before the 2012 parliamentary and presidential elections. This successful PS-EELV coalition under President François Hollande promised to reduce the share of nuclear energy in France's electricity mix to $50 \%$ by 2025 , amounting to the closure of 24 nuclear reactors. ${ }^{\prime}$ Needless to say, the full political outcomes of the Fukushima nuclear disaster in France are still becoming known.

As Germany already had a shared understanding of the problems of nuclear energy in place, anti-nuclear proponents could take advantage of the many political opportunities afforded to them in early 2011 and there were many. Fukushima was the major mobilizing political opportunity but this political opportunity intersected with others in a 'perfect storm' of systemic political opportunities. As mentioned, Germany was in the midst of a 'super' election year but there were also several other political opportunities that appeared during this time, namely arising from Germany's relationship with Japan, the anniversaries of previous nuclear disasters, and its history of previous anti-nuclear mobilizations. The importance of elections as a political opportunity cannot

\footnotetext{
'Angelique Chrisafis, "Nuclear row splits French government," The Guardian, 28 August 2012. Retrieved from http://www.guardian.co.uk/world/2012/aug/28/nuclear-row-splits-french-government on 12 March 2013.
} 
be overestimated. Unlike France, which was approximately a year away from its 2012 parliamentary and presidential elections, Germany faced elections in almost a third of its states with four in the immediate aftermath of Fukushima, making it far more vulnerable to calls for action on nuclear energy. However, it is this 'perfect storm' of political opportunities that encourages caution in applying this paper's conclusions to other cases.

While the necessity of framing and political opportunities is likely to be validated through the examination of other cases, the extreme policy change of Germany is due to the extent of the German electoral opportunities during 2011, which made the potential expression of this framing unparalleled in Europe and the world at the time. This contextualization of Germany's reaction can be seen through the overall maintaining of the status quo globally following the Fukushima disaster. Thus, in a sense, this case study offers an 'overexplained' outcome; as the German case was resplendent in explanatory variables and so many of these variables differed between France and Germany, it is difficult for this paper to confidently identify which factors were critical in the German case.

Nevertheless, this paper has sought to make a contribution to the field in its application of previously supported theories to the new case study of the Fukushima nuclear disaster. However, there are still many avenues for further study, particularly as more time passes and a fuller picture emerges of post-Fukushima outcomes. For example, the 2012 election of François Hollande as president of a PS-EELV cabinet promised that nuclear energy would be reduced as part of France's energy mix and that Fessenheim would be decommissioned. However, as recently as August 2012, doubts emerged about 
this direction. ${ }^{2}$ In the future, this topic would benefit from more quantitative assessments of the themes identified within this paper, possibly through a survey of public opinion through future Eurobarometer datasets or a Kolb-style analysis to European nuclear program deviation post-Fukushima. Another area of possible study would be considering the degree to which the German decision influenced the framing discussion and outcomes in France. This paper demonstrated how avidly the German political climate and nuclear exit was covered by the French media so it would be interesting to try to assess how (or if) this interest manifested itself in changes to the French nuclear discourse or policies.

Such future study should be encouraged as this field of study is valuable because nuclear policy as applied to civilian nuclear programs is an often overlooked area of government policy that exemplifies traditional challenges such as the relationship between government and industry as well as balancing security considerations with transparency in a democratic context. Furthermore, the evocative nature of nuclear energy as a single issue (i.e. that a single issue could prompt the closure of an industry) allows scholars to more easily trace how citizens can manifest changes to the political environment within a complex policy arena.

\footnotetext{
${ }^{2}$ Angelique Chrisafis, "Nuclear row splits French government," The Guardian, 28 August 2012.
} 


\section{Bibliography}

\section{Primary Sources}

"25 Jahre nach dem Super-GAU; Ex-Tschernobyl-Direktor warnt vor neuer Katastrophe," Süddeutsche Zeitung Online, 8 April 2011, Factiva.

"25 Stunden für die Rettung der Welt; Die Großen Acht haben so viele Themen auf dem Konferenztisch, dass manchem davon schon vorher ganz schwindelig ist," Süddeutsche Zeitung, 26 May 2011, Factiva.

ABB. Germany: Energy Efficency Report, last update in January 2011. Retrieved from http://www05.abb.com/global/scot/scot316.nsf/veritydisplay $/ 5793753 \mathrm{~d} 3056 \mathrm{bfb} 4 \mathrm{c}$ $12578640051183 \mathrm{f} /$ Sfile/Germany.pdf on 16 April 2013.

"Abschalten! Sofort! Die plötzliche Kehrtwende in der deutschen Atompolitik macht ihre Protagonisten völlig unglaubwürdig," Süddeutsche Zeitung, 19 March 2011, Factiva.

“„Absoluter Schwerpunkt“; Die Sondersendungen im Fernsehen zur Katastrophe in Japan," Süddeutsche Zeitung, 14 March 2011, Factiva.

"Accident nucléaire au Japon : les autorités françaises se veulent rassurantes," LeMonde.fr, 13 March, Eureka.cc.

Ackerman, Galia. "Fukushima : si on tirait des leçons de Tchernobyl ?" Libération, 25 April 2011, Factiva.

Alemagna, Lilian. "En quête d'atomes crochus avec le PS," Libération, 3 June 2011, Factiva.

Alexander, Robin. "CDU: Kernkraft ist schuld an Niederlage," Die Welt, 29 March 2011, Factiva.

"Anti-AKW-Demo im Ländle; "Abschaldä statt schwätza"," Süddeutsche Zeitung Online, 12 March 2011, Factiva.

Appert, Olivier. "Pour un débat serein et global sur l'énergie," Le Figaro, 30 May 2011, Factiva.

"Après Fukushima : "l'écologie est la plus grande des nécessités dans nos démocraties"," LeMonde.fr, 5 April 2011, Eureka.cc.

Armanet, Max. "Le futur impensé," Libération, 29 April 2011, Factiva. 
Arnaud, Régis. "Au Japon, l'image de la France se rétablit," Le Figaro, 4 April 2011, Factiva.

"Atomausstieg; Energieagentur warnt vor deutschem Alleingang," Süddeutsche Zeitung Online, 23 May 2011, Factiva.

"Atomausstieg stresst das Stromnetz," Die Welt, 3 June 2011, Factiva.

"Atomdebatte in Deutschland; 60.000 Atomkraftgegner protestieren in Stuttgart," Süddeutsche Zeitung Online, 12 March 2011, Factiva.

“Atomkonzern EnBW will grün warden," Die Welt, 20 April 2011, Factiva.

"Atomkraft spaltet Parteien; Stilllegung von Isar 1: CSU und SPD beziehen gegensätzliche Positionen," Süddeutsche Zeitung, 16 March 2011, Factiva.

"Atomkraftwerke in Deutschland; SPD setzt Regierung bei Atompolitik unter Druck," Süddeutsche Zeitung Online, 14 March 2011, Factiva.

"Atompolitik: Konsequenz aus Japan-Katastrophe; Regierung erwägt Aussetzung der Laufzeitverlängerung," Süddeutsche Zeitung Online, 14 March 2011, Factiva.

"Audit public des réacteurs français François Fillon a ordonné hier l'inspection des 58 réacteurs nucléaires français par l'Autorité de sûreté nucléaire," LeMonde.fr , 25 March 2011, Eureka.cc.

Auer, Katja. "Mitregieren bringt keine Bonuspunkte; Während sich die CSU wachsenden Zuspruchs erfreut, schwinden die Sympathien der Bürger im Freistaat für die FDP," Süddeutsche Zeitung, 22 March 2011, Factiva.

Auffray, Elodie. "Les altermondialistes en petite délégation au Havre," Libération, 23 May 2011, Factiva.

“Ausland; Manifest gegen Sarkozy," Süddeutsche Zeitung, 6 April 2011, Factiva.

"Außenansicht; Die Bürger als Zuschauer; Demokratie wird allzu oft als Regieren für das Volk verstanden, nicht als Regieren durch das Volk," Süddeutsche Zeitung, 27 April 2011, Factiva.

"Außenansicht; Politik in Zeiten der Furcht; Atomkrise und Libyen-Krieg: Wieder einmal spotten Nachbarn in Europa über die „German Angst" - zu Unrecht," Süddeutsche Zeitung, 31 March 2011, Factiva.

Baborka, Christoph. "Krank und fatalistisch; Wie die Poinger Gomelhilfe die Opfer von Tschernobyl erlebt," Süddeutsche Zeitung, 15 March 2011, Factiva. 
Baïetto, Thomas. "Allemagne : une sortie du nucléaire progressive," LeMonde.fr, 31 May 2011, Eureka.cc.

Baietto, Thomas. "Nucléaire français : les propos de M. Besson passés au crible," LeMonde.fr, 1 June 2011, Eureka.cc.

Balser, Markus. "Ausstieg aus dem Kuschelkurs; Eon-Chef Johannes Teyssen geht in der Atomdebatte auf Konfrontationskurs zu Bundeskanzlerin Angela Merkel," Süddeutsche Zeitung, 6 May 2011, Factiva.

Balser, Markus. "Chef-Etage abgeschaltet; Die Energiebranche fürchtet nach dem Ende für die Kernkraft in Deutschland Milliarden-Ausfälle. Der Streit mit der Politik eskaliert," Süddeutsche Zeitung, 31 May 2011, Factiva.

Balser, Markus. "Es geht doch; Konzerne erwarten keinen Engpass bei Stromversorgung," Süddeutsche Zeitung, 16 March 2011, Factiva.

Balser, Markus. "Falsch gepolt; Mit den Unfällen in Japan schwindet auch die Macht der einst gefürchteten deutschen Energiebosse. Dem Votum der Regierung haben sie nichts entgegenzusetzen," Süddeutsche Zeitung, 16 March 2011, Factiva.

Balser, Markus. "Katastrophe in Japan: Politik und Wirtschaft debattieren über die Zukunft deutscher Kernkraftwerke; „Stilllegen ist möglich“; Atom-Lobbyist Ralf Güldner über Sorgen der Branche," Süddeutsche Zeitung, 15 March 2011, Factiva.

Balser, Markus. "Kommentare; Kurzschluss; Im Atomstreit manövrieren sich die Energiekonzerne ins Abseits," Süddeutsche Zeitung, 8 June 2011, Factiva.

Balser, Markus, Michael Kläsgen and Gunnar Herrmann. "Angst um die Rendite; Die Atomkonzerne beklagen sich bei der Bundesregierung," Süddeutsche Zeitung, 8 June 2011, Factiva.

Barotte, Nicolas. "Au PS, la « sortie du nucléaire » en débat," Le Figaro, 8 April 2011, Factiva.

Barotte, Nicolas. "Socialistes et écologistes se donnent du temps pour négocier," Le Figaro, 3 May 2011, Factiva.

Bauchmüller, M., B. Dörries and D. Brössler. "Atomunfall in Japan: In Deutschland flammt die Debatte über die Kernenergie wieder auf; Ein neues altes Problem; Erst war Umweltminister Norbert Röttgen gegen die Laufzeit-Verlängerungen von Atomkraftwerken, dann dafur - jetzt holt ihn die Diskussion ein," Süddeutsche Zeitung, 14 March 2011, Factiva. 
Bauchmüller, Michael. "Das Preisrätsel; Wie teuer der Strom wird, zählt zu den Unbekannten des Atomausstiegs. Jetzt geben die Stadtwerke überraschend Entwarnung," Süddeutsche Zeitung, 11 May 2011, Factiva.

Bauchmüller, Michael. "Eine Frage der Auslegung; Erdbeben, Hochwasser, Terrorangriffe: Der Prüfbericht zur Sicherheit deutscher Kernkraftwerke ist in vielen Punkten vage," Süddeutsche Zeitung, 18 May 2011, Factiva.

Bauchmüller, Michael. "Energiewende; Ethikkommission empfiehlt Ausstieg binnen zehn Jahren," Süddeutsche Zeitung Online, 28 May 2011, Factiva.

Bauchmüller, Michael. "Kommentar; Rosenkrieg um Reaktoren; Die Regierung lässt die Stromkonzerne fallen. Die Folgen reichen weit," Süddeutsche Zeitung, 14 June 2011, Factiva.

Bauchmüller, Michael. "Mehr Klimaschutz im Baurecht; Pläne der Bundesregierung: Kommunen sollen zusätzliche Flächen für Windräder und Solaranlagen ausweisen," Süddeutsche Zeitung, 16 May 2011, Factiva.

Bauchmüller, Michael. "Reaktorexperten präsentieren Gutachten; Schlechte Noten für sieben Atomkraftwerke; Alte Meiler bei einem Flugzeugabsturz nicht sicher / Röttgen: Insgesamt sind die deutschen Anlagen aber „robust“,”Süddeutsche Zeitung, 18 May 2011, Factiva.

Bauchmüller, Michael. "Sieben deutsche Reaktoren werden abgeschaltet; Bund und Länder legen alte Atomkraftwerke vorübergehend still / Neckarwestheim 1 geht endgültig vom Netz," Süddeutsche Zeitung, 16 March 2011, Factiva.

Bauchmüller, Michael. "Von diesem Wochenende an; Mehr Ökostrom als Atomenergie; Weitere Meiler zur Wartung abgeschaltet / Jetzt sind nur noch vier der 17 Kernkraftwerke am Netz," Süddeutsche Zeitung, 21 May 2011, Factiva.

Bauchmüller, Michael. "Von Spätzündern und Frühaufstehern; Die CDU redet ihr Ergebnis schön, die Liberalen sprechen sich Mut zu, die SPD schaut nach vorne nur die Grünen freuen sich im Hier und Jetzt," Süddeutsche Zeitung, 21 March 2011, Factiva.

Bauchmüller, Michael. "Zweifel an Atomaufsicht; Umweltschützer und Grüne fordern unabhängige Prüfung," Süddeutsche Zeitung, 22 March 2011, Factiva.

Bauchmüller, Michael and Stefan Braun. "Merkel sucht neuen Atomkonsens; Kommission aus Bischöfen, Wissenschaftlern und ehemaligen Ministern soll Streit uber Kernenergie schlichten,” Süddeutsche Zeitung, 23 March 2011, Factiva. 
Bauchmüller, Michael and Susanne Höll. "Bischöfe gegen Atomstrom; Kirchen fordem rascheren Ausstieg, SPD bietet neuen Energiekonsens an," Süddeutsche Zeitung, 21 March 2011, Factiva.

Bauchmüller, Michael and Susanne Höll. "Dafür ist genauso schwer wie dagegen; RotGrün wollte das Ende der Kernkraft selbst schon lange durchsetzen - deshalb zögert die skeptische Opposition jetzt damit, einen Konfrontationskurs einzuschlagen," Süddeutsche Zeitung, 31 May 2011, Factiva.

Beck, Ulrich. "C'est le mythe du progrès et de la sécurité qui est en train de s'effondrer," LeMonde.fr, 25 March 2011, Eureka.cc.

Becker, Peter. "Hamsterkäufe in Supermärkten; Nach der Reaktorkatastrophe in Tschernobyl vor 25 Jahren kaufen die Bürger nur noch Konserven und verzichten auf Frischgemüse," Süddeutsche Zeitung, 11 April 2011, Factiva.

Bennahmias, Jean-Luc, François de Rugy, Guy Hascoët, and Yannick Jadot. "L'humanité a droit à la vérité sur le nucléaire," LeMonde.fr, 25 March 2011, Eureka.cc.

Bensimon, Corinne. "Chocs de chiffres," Libération, 27 April 2011, Factiva.

Berr, Christina Maria. "Japan: Boom der Nachrichtensendungen; Super-GAU als TVHighlight," Süddeutsche Zeitung Online, 17 March 2011, Factiva.

Berr, Christina Maria."TV-Programm zum Erdbeben in Japan; Großes Interesse an Sondersendungen," Süddeutsche Zeitung Online, 13 March 2011, Factiva.

Berth, Felix. "Jung, sprunghaft, grün; Die Atomdebatte hat viele Nichtwähler mobilisiert," Süddeutsche Zeitung, 29 March 2011, Factiva.

Bezat, Jean-Michel. "Electricité : la nouvelle loi va-t-elle entraîner une hausse des prix ?" LeMonde.fr, 19 May 2011, Eureka.cc.

Bezat, Jean-Michel. "Fukushima "ne remet pas en cause le nucléaire", selon le patron d'EDF," LeMonde.fr, 25 May 2011, Eureka.cc.

Biberian, Jean-Paul. "L'énergie nucléaire est-elle nécessaire ?" LeMonde.fr, 1 April 2011, Eureka.cc.

Bigot, Bernard. "Pourquoi la France a besoin de l'atome," Le Figaro, 3 June 2011, Factiva.

"Bilder des Erdbebens; Gefangen im braunem Schlamm," Süddeutsche Zeitung Online, 11 March 2011, Factiva. 
Blechschmidt, Peter. "Kritik aus der zweiten Reihe; In der FDP regt sich Unmut über die Stilllegung," Süddeutsche Zeitung, 16 March 2011, Factiva.

Bohsem, Guido. "Schäuble kürzt den Wehretat; Die Regierung plant Haushalt mit Steuer auf Atom-Elemente. Die Neuverschuldung soll bis 2015 auf 13,3 Milliarden Euro sinken," Süddeutsche Zeitung, 15 March 2011, Factiva.

Bolzen, Stefanie. "Europa bei AKW-Stresstests gespalten," Die Welt, 20 May 2011, Factiva.

Bourmaud, François-Xavier. "Hulot ne veut plus du nucléaire," Le Figaro, 26 April 2011, Factiva.

Bouthier, Antoine. "La crise nucléaire, une épreuve difficile pour la diplomatie française au Japon," LeMonde.fr, 2 April 2011, Eureka.cc.

Bouthier, Antoine. "Nucléaire : le Japon avait été alerté d'irrégularités à Fukushima," LeMonde.fr, 23 March 2011, Eureka.cc.

Bouzou, Nicolas. "Comme en Allemagne, ouvrons le débat sur le nucléaire," LeMonde.fr, 16 June 2011, Eureka.cc.

Brautlecht, Nicholas. "Japan und die Atomkatastrophe: Fukushima auf gleicher Stufe mit Tschernobyl - Die Not der Evakuierten - Die Folgen für die Wirtschaft Gesundheitsrisiken für die Menschen - So schlimm wie Tschernobyl," Die Welt, 13 April 2011, Factiva.

Brautlecht, Nicholas. "Tokio greift nach Tepco," Die Welt, 30 March 2011, Factiva.

Brill, Klaus. "Weiterbauen! Osteuropa setzt auf Atomenergie - der Super-GAU in Fukushima hat daran wenig geändert," Süddeutsche Zeitung, 17 March 2011, Factiva.

Brössler, Daniel. "Deutschland streitet wieder über Kernenergie; SPD-Chef Gabriel: Das Atomzeitalter ist zu Ende / Bundesregierung gegen neue Debatte über Laufzeiten," Süddeutsche Zeitung, 14 March 2011, Factiva.

"Bundesweite Proteste gegen Atomkraft; "AKW? Neee!"," Süddeutsche Zeitung Online, 28 May 2011, Factiva.

Büschemann, Karl-Heinz. "Kommentar; Atom ist totalitär; Kernkraft hat in Demokratien und Marktwirtschaften keine Zukunft," Süddeutsche Zeitung, 16 June 2011, Factiva. 
Büschemann, Karl-Heinz. "Kommentar; Raumschiff Berlin; Regierung und Wirtschaft misstrauen einander - das ist gefährlich," Süddeutsche Zeitung, 31 May 2011, Factiva.

Caresche, Christophe, Jean-Paul Chanteguet, Aurélie Filippetti, MPs (PS), and Géraud Guibert, PS Ecological Division Leader. "Sortons du nucléaire," LeMonde.fr , 8 April 2011, Eureka.cc.

Chat with Bernard Laponche moderated by Grégoire Allix et Emmanuelle Chevallereau."Tous les prétextes ont été bons pour limiter le développement des énergies renouvelables," LeMonde.fr, 6 April 2011, Eureka.cc.

Chat with Noël Mamère moderated by Eric Nunès."Sarkozy "un VRP d'Areva qui voulait vendre une centrale nucléaire à Kadhafi"," LeMonde.fr, 17 March 2011, Eureka.cc.

Chat with Pierre Le Hir moderated by François Béguin. "Fukushima est-il un nouveau Tchernobyl ?" Le Monde, 17 March 2011, Eureka.cc.

Chrisafis, Angelique. "Nuclear row splits French government." The Guardian, 28 August 2012. Retrieved from http://www.guardian.co.uk/world/2012/aug/28/nuclear-rowsplits-french-government on 12 March 2013.

Collen, Vincent."Le Commissariat à l'énergie atomique élargit son champ aux énergies alternatives," LesEchos.fr, 15 December 2009. Retrieved from http://www.lesechos.fr/15/12/2009/LesEchos/20573-13-ECH le-commissariat-a1-energie-atomique-elargit-son-champ-aux-energies-alternatives.htm on 13 February 2013.

Conférence de presse conjointe de M. Nicolas Sarkozy et Mme Angela Merkel, à Berlin. 17 June 2011. Retrieved from http://www.elysee.fr/president/les-actualites/ conferences-de-presse $/ 2011 /$ conference-de-presse-conjointe-de-m-nicolas. 11589.html? search=Fukushima\&xtmc=fukushima\&xcr=8 on 21 January 2012.

Courtois, Claudia."La centrale nucléaire s'impose dans la campagne électorale en Gironde," LeMonde.fr, 22 March 2011, Eureka.cc.

Crossland, David. "Guttenberg Fallout: Merkel Loses Heavyweight Minister, Gains Power," Spiegel Online, 1 March 2011. Retrieved from http://www.spiegel.de/international/germany/guttenberg-fallout-merkel-losesheavyweight-minister-gains-power-a-748422.html on 12 March 2013.

Das Gupta, Oliver. "Atomwende; Ex-CSU-Chef Huber warnt Kanzlerin vor Zickzackkurs," Süddeutsche Zeitung Online, 15 March 2011, Factiva. 
Dauphin, François. "Faut-il assurer le nucléaire ?"," LeMonde.fr, 6 April 2011, Eureka.cc.

de Beaupuy, Francois. "Areva's Lauvergeon Denied Third Term as France Names Oursel as New Chief," Bloomberg, 17 June 2011. Retrieved from http://www.bloomberg.com/news/2011-06-17/areva-s-lauvergeon-denied-thirdterm.html on 23 January 2013.

De Monicault, Frédéric. "L'EPR de Flamanville devra tirer les leçons de Fukushima," Le Figaro, 1 April 2011, Factiva.

De Monicault, Frédéric. "La fin du nucléaire en Allemagne dérègle le marché européen de l'électricité," Le Figaro, 31 May 2011, Factiva.

De Monicault, Frédéric. "Prix de l'électricité : GDF Suez très mécontent," Le Figaro, 20 April 2011, Factiva.

De Monicault, Frédéric. "Prix de l'énergie : l'État décrète une pause," Le Figaro, 6 April 2011, Factiva.

"Debatte um Atomausstieg; Umweltminister wollen alte Meiler endgültig stilllegen," Süddeutsche Zeitung Online, 27 May 2011, Factiva.

Deininger, Roman. "Gegen den Sog der Ereignisse; In Baden-Württemberg kommt der Atom-Befürworter Stefan Mappus in Bedrängnis," Süddeutsche Zeitung, 14 March 2011, Factiva.

Deininger, Roman and Holger Gertz. "German Angst; Hans Söllner singt, 60000 demonstrieren, und Guido Westerwelle spricht viel über die Hundestaffel: Das Wochenende von Japan bescherte Deutschland eine Reise zurück in die 1980er Jahre," Süddeutsche Zeitung, 14 March 2011, Factiva.

Delfour, Jean-Jacques. "Nucléaire et jouissance technologique," LeMonde.fr, 12 April 2011, Eureka.cc.

"Demonstration und Mahnwache; SPD und Grüne rufen zu Aktionen gegen Atomkraft in Bruck auf," Süddeutsche Zeitung, 18 March 2011, Factiva.

Denkler, Thorsten. "Analyse - Folgen der Bremen-Wahl; Etappensieger auf dem Weg nach Berlin," Süddeutsche Zeitung Online, 23 May 2011, Factiva.

Denkler, Thorsten. "Bundesregierung ändert Atomkurs; Merkel will Laufzeitverlängerung aussetzen," Süddeutsche Zeitung Online, 14 March 2011, Factiva. 
Denkler, Thorsten. "Expertenbericht zur Reaktorsicherheit; Röttgens Wunschergebnis," Süddeutsche Zeitung, 17 May 2011, Factiva.

Denkler, Thorsten. "Zweifel am Atomkurs der Koalition; "Atomkraft, nein danke" Danke, nein!," Süddeutsche Zeitung Online, 8 April 2011, Factiva.

Denkler, Thorsten, Oliver Das Gupta and Jens Schneider. "Japan und die Folgen: Bundesregierung ändert Kurs; Merkel setzt Laufzeitverlängerung aus," Süddeutsche Zeitung Online, 14 March 2011, Factiva.

"Des experts américains redoutent un Tchernobyl au Japon," LeMonde.fr, 13 March 2011, Eureka.cc.

Deutscher Bundestag. Entwurf eines Dreizehnten Gesetzes zur Änderung des Atomgesetzes. Drucksache 17/6070. 6 June 2011. Retrieved from http://dipbt. bundestag.de/dip21/btd/17/060/1706070.pdf on 20 January 2012.

Diermann, Ralph. "Mehr Sonne im Strom; Der Anteil der Photovoltaik am Strommix in Deutschland soll sich bis 2020 fast vervierfachen. Forscher und Unternehmen lehnen Deckelung des Anlagen-Zubaus ab," Süddeutsche Zeitung, 6 June 2011, Factiva.

Diermann, Ralph. "Sonnenkraft für übermorgen; Deutsche Forschungsinstitute sind weltweit fuhrend bei der Weiterentwicklung der Solarenergie," Süddeutsche Zeitung, 4 June 2011, Factiva. .

"Direct : les côtes japonaises frappées par un tsunami," Le Monde.fr, 11 March 2011, Eureka.cc.

Doemens, Karl. "Grüne wollen für Merkels Atomgesetz stimmen - Der Leitantrag zum grünen Sonderparteitag löst Kritik an der Basis und bei Umweltverbänden aus," Berliner Zeitung, 18 June 2011, Factiva.

"Dokumentation; Die weltweit schwersten Erdbeben," Süddeutsche Zeitung Online, 11 March 2011, Factiva.

"Drohender Atom-GAU in Japan; Wie sicher sind die deutschen AKWs?" Süddeutsche Zeitung Online, 12 March 2011, Factiva.

Ehrenstein, Claudia. "25 Glockenschläge zum Gedenken an Tschernobyl-Opfer," Die Welt, 27 April 2011, Factiva

Ehrenstein, Claudia. "'Nur der Ausstieg schafft Sicherheit"," Die Welt, 11 May 2011, Factiva. 
"Eins auf die Mütze; CDU und FDP lernen nun auch dort, wo sie seit jeher auf Siege abonniert waren, was eine herbe Niederlage ist," Süddeutsche Zeitung, 28 March 2011, Factiva.

Engelhardt, Marc. "UN verzweifeln an Japans Atomchaos - Chef der Umweltbehörde Steiner mahnt bessere Informationspolitik der Regierung an Merkel bietet deutsche Hilfe an / EU setzt Strahlengrenzwerte für Lebensmittel herauf," Berliner Zeitung, 31 March 2011, Factiva.

"Erdbeben in Japan; AKW nur noch mit Batterie gekühlt," Süddeutsche Zeitung Online, 11 March 2011, Factiva.

"Erdbeben in Japan; Sorge um Japans Wirtschaft erfasst Finanzmärkte," Süddeutsche Zeitung Online, 11 March 2011, Factiva.

"Ethikkommission zur Atompolitik; "Ein biblisches Gebot"," Süddeutsche Zeitung Online, 4 April 2011, Factiva.

"EU verzichtet auf strenge Reaktor-Tests; Berlin empört sich über Brüssel," Süddeutsche Zeitung Online, 4 May 2011, Factiva.

"Eva Joly demande un audit sur les centrales françaises par un pays tiers," LeMonde.fr, 19 April 2011, Eureka.cc.

Federal Foreign Office of Germany. "Germany and Japan: 150 Years of Friendship," Federal Foreign Office Website (last updated on 20 January 2011). Retrieved from http://www.auswaertiges-amt.de/EN/ Aussenpolitik/RegionaleSchwerpunkte /Asien/AktuelleArtikel/110119-150J-Dt-Japan node.html on 25 February 2013.

Féraud, Jean-Christophe. "Sécurité, EPR, otages ... du pain sur la planche chez Areva," Libération, 18 June 2011, Factiva.

Fischer, Joschka. "Außenansicht; Geliebte Bombe; Warum die Atomwaffenmächte auch nach Fukushima keinen Ausstieg aus der Nuklearenergie wollen," Süddeutsche Zeitung, 10 May 2011, Factiva.

François, Géal. "Il faut sortir de la religion de l'atome," LeMonde.fr, 18 March 2011, Eureka.cc.

Fras, Damir. "Der Wandel der Kanzlerin - In Offenburg versucht Angela Merkel, ihren Kurswechsel zu erklären - Katastrophe in Japan," Berliner Zeitung, 17 March 2011 , Factiva.

Fried, Nico. "Angela Merkel und die Atomkraft; Die Stimmungskanzlerin," Süddeutsche Zeitung Online, 16 March 2011, Factiva. 
Fried, Nico. "Atomausstieg im Schnellverfahren; Merkel und die Ministerpräsidenten verkürzen Fristen, um Gesetz bereits im Juni verabschieden zu können," Süddeutsche Zeitung, 16 April 2011, Factiva.

Fried, Nico. "Merkels Restrisiko," Süddeutsche Zeitung, 14 March 2011, Factiva.

Fried, Nico, Peter Blechschmidt, Stefan Braun and Daniel Brössler. "Wir sind doch nicht blöd; Union und FDP weigern sich, eine Sache zu verteidigen, die in Deutschland keine Zukunft hat: Wie sich die Koalition in Berlin plötzlich von der Kernenergie verabschiedet," Süddeutsche Zeitung, 15 March 2011, Factiva.

Frigelj, Kristian. "Die CDU traut sich nicht mehr," Die Welt, 18 May 2011, Factiva.

Fuchs, Christian. "Energiewende und German Angst; Nach dem Atomausstieg fürchten manche den Niedergang des Hochtechnologie-Standorts Deutschland - andere sind froh, dass neue Wege aufgezeigt warden," Süddeutsche Zeitung, 3 June 2011, Factiva.

Fuchs, Florian."Protest hat Konjunktur; Wegen Fukushima haben die Ostermärsche Zulauf," Süddeutsche Zeitung, 23 April 2011, Factiva.

"Fukushima, verweht; Von Heribert Prantl," Süddeutsche Zeitung, 11 April 2011, Factiva.

Gamillscheg, Hannes, P. Frank Herold, Thorsten KnufP, and Axel Veiel. "Nachbarn bauen weiter auf Atomenergie - Die EU beschließt Sicherheitschecks in allen Kraftwerken, aber einige Länder sehen keine Notwendigkeit zum Umdenken," Berliner Zeitung, 16 March 2011, Factiva.

Gammelin, Cerstin. "Atompolitik spaltet Europa; EU-Länder können sich nicht auf gemeinsame Sicherheitsprüfung aller Meiler einigen," Süddeutsche Zeitung, 22 March 2011, Factiva.

Gammelin, Cerstin."EU verzichtet auf strenge Reaktor-Tests; Mögliche Folgen von Flugzeugabstürzen oder von menschlichem Versagen sollen nicht untersucht werden," Süddeutsche Zeitung, 4 May 2011, Factiva.

Gammelin, Cerstin. "Europa; Gespaltene Gemeinschaft; Energiekommissar Günther Oettinger hat große Ziele, die Umsetzung aber bereitet große Probleme," Süddeutsche Zeitung, 13 April 2011, Factiva.

Gammelin, Cerstin. "Stresstests ohne Stress; Überprüfung der Atommeiler in der EU bleibt freiwillig," Süddeutsche Zeitung, 26 March 2011, Factiva. 
Gammelin, Cerstin and Michael Frank. "Stresstest für Europas Meiler; Brüssel will die Sicherheit der Atomkraftwerke überprüfen lassen / Österreich fühlt sich besonders bedroht," Süddeutsche Zeitung, 15 March 2011, Factiva.

“Garching," Süddeutsche Zeitung, 19 March 2011, Factiva.

Geisler, Rodolphe. "Nucléaire : les écolos accentuent la pression sur le PS," Le Figaro, 10 June 2011, Factiva.

Geyer, Steven. "Bundesregierung - Umsteuern mit leichter Verspätung," Berliner Zeitung, 9 May 2011, Factiva.

Geyer, Steven and Jacob Schlandt. "Sieben Atommeiler auf einen Streich Umweltminister Röttgen will nach Stresstest die ältesten Kraftwerke vom Netz nehmen - Sie sind nicht gegen Flugzeugabstürze gesichert / Genereller Sofortausstieg abgelehnt," Berliner Zeitung, 18 May 2011, Factiva.

Gläßer, Daniel. "Rückenwind für Windkraft; Erstmals befürworten die beiden Dachauer Landtagsabgeordneten öffentlich das umstrittene Vorhaben bei Odelzhausen," Süddeutsche Zeitung, 16 March 2011, Factiva.

Gnauck, Gerhard. "Polen will die Unabhängigkeit, " Die Welt, 26 March 2011, Factiva.

"Gundremmingen; Mit Totenköpfen und Ballons gegen Atomkraft," Süddeutsche Zeitung, 14 May 2011, Factiva.

Hägler, Max."Anti-Atom-Demo am AKW Isar 1; "Jetzt reicht's!"' Süddeutsche Zeitung Online, 14 March 2011, Factiva.

Hebestreit, Steffen. "Angst vor der grünen Zukunft - Die FDP führt in Stuttgart und Mainz Wahlkampf gegen einen neuen Gegner: Restrisiko und AKW-Laufzeiten," Berliner Zeitung, 22 March 2011, Factiva.

Hebestreit, Steffen, P. Karl Doemens and Daniela Vates. "Die FDP hadert mit dem Atomausstieg," Berliner Zeitung, 8 June 2011, Factiva.

Heithecker, Marcus and Tina Kaiser. "Nur Italien teilt die deutschen Ängste," Die Welt, 27 May 2011, Factiva.

Helbig, Felix. "Auf der anderen Seite - Seit dem Unglück von Fukushima sind in Deutschland viele für einen schnellen Ausstieg aus der Atomenergie. Einige der anfälligsten Meiler Europas stehen allerdings dicht hinter der Grenze in Nachbarländern. - Das führt zu Konflikten, immer wieder. Doch die AKWGegner vor Ort sind zähe Kämpfer," Berliner Zeitung, 14 April 2011, Factiva.

Held, Gerd. "Dem Atom eine Chance," Die Welt, 17 May 2011, Factiva. 
Held, Gerd. "Der große Ausstieg," Die Welt, 3 June 2011, Factiva.

Herrmann, Gunnar. "Sorglose Skandinavier; Nordeuropäer bauen trotz Unglück in Japan neue Meiler," Süddeutsche Zeitung, 15 March 2011, Factiva.

Hervé, Eric and Pascal Tréhet. "Pour une gestion supranationale de la sûreté nucléaire," LeMonde.fr, 6 April 2011, Eureka.cc.

Hildebrand, Jan, Thorsten Jungholt, and Daniel Friedrich Sturm. "Für das Protokoll: Das Atom-Moratorium ist (kein) Wahlkampf," Die Welt, 25 March 2011, Factiva.

Höll, Susanne. "Angriff in aller Pietät; SPD und Grüne attackieren den Atomkurs der Regierung - wegen der vielen Opfer in Japan aber nicht allzu harsch," Süddeutsche Zeitung, 15 March 2011, Factiva.

Hollinger, Peggy. "Areva and EDF spat shows nuclear tensions," Financial Times, 19 January 2010. Retrieved from http://www.ft.com/cms/s/0/6d4e 729e-052a-11dfa85e-00144feabdc0.html\#axzz2PRGs5SjZ on 14 February 2013.

Hörr, Susanne. "Die neue Protestbewegung - Mehr als 100000 Menschen demonstrierten für einen schnellen Atomausstieg. Viele Neulinge waren dabei," Berliner Zeitung, 28 March 2011, Factiva.

Huchon, Jean-Paul. "Pour sortir du nucléaire, il faut d'abord réussir la conversion énergétique," LeMonde.fr, 6 April 2011, Eureka.cc.

Huet, Sylvestre. "Fukushima. Repères," Libération, 26 May 2011, Factiva.

Hugues, Pascale."Die Strahlung, die am Rhein anhielt; Tschernobyl, na und? Warum Deutsche und Franzosen ein so unterschiedliches Verhältnis zur Atomkraft haben," Süddeutsche Zeitung, 5 April 2011, Factiva.

Humbert, Marc. "Japon : alerte verte et rouge," LeMonde.fr, 23 March 2011, Eureka.cc.

"IEA warns Merkel on nuclear decision," United Press International, 23 May 2011.

Retrieved from http://www.upi.com/Business News/Energy-

Resources/2011/05/23/IEA-warns-Merkel-on-nuclear-decision/UPI$\underline{11251306169748 / \text { on } 14 \text { January } 2013 .}$

Interview with Christian Navarre by Marion Solletty. "Devant la catastrophe au Japon, "un stress collectif mondial"," LeMonde.fr, 17 March 2011, Eureka.cc.

Interview with Jacques Repussard by Marc Mennessier. "Accident nucléaire : «Il faut imaginer l'inimaginable ", “ Le Figaro, 18 June 2011, Factiva. 
Interview with Stéphane Le Foll conducted by Alexandre Piquard. "PS : "Un référendum sur le nucléaire, c'est précipité"," LeMonde.fr, 15 March 2011, Eureka.cc.

Jaigu, Charles. "À Tokyo, Sarkozy réaffirme son choix du nucléaire," Le Figaro, 1 April 2011, Factiva.

Jakat, Lena and Oliver Das Gupta. "Brüderle, das Moratorium und der Wahlkampf; Regierung geht in Deckung, Opposition frohlockt," Süddeutsche Zeitung Online, 24 March 2011, Factiva.

Jancovici, Jean-Claude. "La main invisible de la radioactivité," Le Figaro, 4 April 2011, Factiva.

"Japan nach dem Erdbeben; 10.000 Vermisste in einer Hafenstadt," Süddeutsche Zeitung Online, 12 March 2011, Factiva.

"Japon : plus de 1800 morts et disparus, un accident nucléaire majeur," LeMonde.fr, 13 March, Eureka.cc.

"Japon : une catastrophe nucléaire menace, le bilan humain reste incertain," LeMonde.fr, 15 March 2011, Eureka.cc.

“ „Japan verändert alles“; Umweltminister Markus Söder plädiert nach dem Atomunfall in Fukushima für einen schnelleren Umstieg auf Öko-Energie," Süddeutsche Zeitung, 14 March 2011, Factiva.

Jozsef, Eric. "L'Italie ne veut pas reprendre de l'atome," Libération, 14 June 2011, Factiva.

Kastner, Bernd."Alles wieder Wut; Lange haben sich die Atomkraftgegner wie einsame Rufer in der Wüste gefühlt - nun blicken sie fassungslos nach Japan," Süddeutsche Zeitung, 15 March 2011, Factiva.

Kechemair, Didier. "Quelles leçons tirer de l'accident de Fukushima?" LeMonde.fr, 25 March 2011, Eureka.cc.

Kepplinger, Mathias. "Phantomangst Atomangst," Die Welt, 11 April 2011, Factiva.

Kirienko, Sergei. "La sûreté nucléaire est notre défi commun," Le Figaro, 26 May 2011, Factiva.

Kister, Kurt. “Atomarer Glaubenskrieg," Süddeutsche Zeitung, 19 March 2011, Factiva.

Kläsgen, Michael. "Atomic-Anne muss gehen; Frankreichs Präsident hat schon oft signalisiert, Areva-Chefin Lauvergeon ablösen zu wollen. Nun ist seine Entscheidung gefallen," Süddeutsche Zeitung, 17 June 2011, Factiva. 
Kläsgen, Michael.“In Frankreich wächst der Zweifel," Süddeutsche Zeitung, 7 April 2011, Factiva.

Kläsgen, Michael. "Japan ist ganz nah; Auch Frankreich verharmlost die Gefahren," Süddeutsche Zeitung, 16 March 2011, Factiva.

Kläsgen, Michael. "Streitende Franzosen; Die Regierung in Paris verteidigt die Atomkraft," Süddeutsche Zeitung, 15 March 2011, Factiva.

Kläsgen, Michael. "Zweifelnde Franzosen; Die Mehrheit würde gern aus der Atomkraft aussteigen. Wenn sie nur nicht so billig ware," Süddeutsche Zeitung, 16 April 2011, Factiva.

"Koalitionsgipfel im Kanzleramt; Regierung plant Atomausstieg bis spätestens 2022," Süddeutsche Zeitung Online, 29 May 2011, Factiva.

Kolb, Matthias. "Kritik an Ausstiegsbeschluss; "Die Hintertürchen sind riesige Tore für die Atomkonzerne"," Süddeutsche Zeitung Online, 30 May 2011, Factiva.

König, Michael. "Atomausstieg: Strompreise; Kampf den Horrorszenarien," Süddeutsche Zeitung Online, 26 May 2011, Factiva.

König, Michael. "Atompolitik: Schwarz-gelbe Kehrtwende; Wo geht's denn hier zum Engpass?" Süddeutsche Zeitung Online, 16 March 2011, Factiva.

König, Michael. "Baden-Württemberg im Wahlkampf; Manöver auf den letzten Metern," Süddeutsche Zeitung Online, 26 March 2011, Factiva.

König, Michael. "Erdbeben in Japan: AKW beschädigt; "Tschernobyl ist die richtige Assoziation"," Süddeutsche Zeitung Online, 11 March 2011, Factiva.

Kotynek, Martin. "Eingebaute Mängel; Die Technik der Alt-Meiler ist überholt und fehleranfallig," Süddeutsche Zeitung, 16 March 2011, Factiva.

Krauel, Torsten. "Die CDU und ihre Grünen," Die Welt, 10 June 2011, Factiva.

"Krisengipfel in Berlin; Töpfer wird oberster Atom-Weiser," Süddeutsche Zeitung Online, 22 March 2011, Factiva.

Krupp, Kerstin and Nicolas Garz. "Berlin. Lässt sich die Atomkatastrophe in Japan noch abwenden? Nach Ansicht von...," Berliner Zeitung, 18 March 2011, Factiva.

Kuhn, Johannes. "Japan: Die Katastrophe und das Web; Vernetzt in Trauer und Furcht," Süddeutsche Zeitung Online, 14 March 2011, Factiva. 
Kulish, Nicholas. "Greens Gain in Germany, and the World Takes Notice," New York Times, 1 September 2011. Retrieved from http://www.nytimes.com/2011/09/02/ world/europe/02greens.html? r=2\&pagewanted=all\& on 20 February 2013.

"L'Allemagne anti-nucléaire Samedi," LeMonde.fr , 28 March 2011, Eureka.cc.

"L'ASN classe l'accident nucléaire de Fukushima au niveau 6," LeMonde.fr, 16 March 2011, Eureka.cc.

Lachmann, Günther. "Deutliche Kritik am System Merkel," Die Welt, 21 May 2011, Factiva

Lagadec, Patrick. "Comment piloter le monde à l'heure des "mégarisques" et "mégacrises"?" LeMonde.fr, 9 May 2011, Eureka.cc.

Laponche, Bernard. "Accident nucléaire : une certitude statistique," Libération, 3 June 2011, Factiva.

Laurent, Samuel. "Comment Hollande, Aubry, Royal et Montebourg se positionnent sur le nucléaire," LeMonde.fr, 2 June 2011, Eureka.cc.

Laurent, Samuel. "Le "lobby nucléaire" existe à gauche comme à droite," LeMonde.fr , 16 March 2011, Eureka.cc.

Lawrence, Samuel. "L'environnement, nouvelle étape de l'opération réconciliation de Nicolas Sarkozy," LeMonde.fr, 23 April 2011, Eureka.cc.

Le Gloannec, Anne-Marie. "L'Allemagne voit plus loin que l'Europe," Le Figaro, 25 March 2011, Factiva.

Lemaître, Frédéric. "Allemagne : mobilisation anti-nucléaire avant un scrutin clé pour Merkel," LeMonde.fr, 26 March 2011, Eureka.cc.

Lemaître, Frédéric. "La chancelière Angela Merkel renonce au dégel du nucléaire allemande," LeMonde.fr, 15 March 2011, Eureka.cc.

Lemaître, Frédéric. "Séisme au Japon: les conséquences politiques et économiques," Le Monde, 15 March 2011, Eureka.cc.

LeMonde.fr with Agence France-Presse (AFP). "Allemagne : EON souligne le risque d'un black-out," LeMonde.fr, 22 March 2011, Eureka.cc.

LeMonde.fr with Agence France-Presse (AFP). "Allemagne : percée des Verts et défaite historique de la CDU dans son propre fief," LeMonde.fr, 28 March 2011, Eureka.cc. 
LeMonde.fr with Agence France-Presse (AFP). "Angoisse pour une deuxième centrale nucléaire au Japon," LeMonde.fr, 13 March 2011, Eureka.cc.

LeMonde.fr with Agence France-Presse (AFP). "Anne Lauvergeon prend la défense du nucléaire français," LeMonde.fr, 15 June 2011, Eureka.cc.

LeMonde.fr with Agence France-Presse (AFP). "Après Fukushima, l'Autorité de sûreté nucléaire évoque un moratoire sur l'EPR de Flamanville," LeMonde.fr, 1 April 2011, Eureka.cc.

LeMonde.fr with Agence France-Presse (AFP). "Areva appelle à une "refondation" de sa relation avec EDF," LeMonde.fr, 22 March 2011, Eureka.cc.

LeMonde.fr with Agence France-Presse (AFP). "Areva aurait demandé à l'Etat d'agir dans son conflit avec EDF," LeMonde.fr, 22 March 2011, Eureka.cc.

LeMonde.fr with Agence France-Presse (AFP). "Areva : l'Etat "essaie" de réaliser l'augmentation de capital d'ici fin 2010," LeMonde.fr , 22 March 2011, Eureka.cc.

LeMonde.fr with Agence France-Presse (AFP). "ASN : l'audit concernera aussi les centrales nucléaires en construction," LeMonde.fr, 2 April 2011, Eureka.cc.

LeMonde.fr with Agence France-Presse (AFP). "Berlin adopte le projet de loi d'abandon du nucléaire," LeMonde.fr , 7 June 2011, Eureka.cc.

LeMonde.fr with Agence France-Presse (AFP). "Berlin prêt à abandonner une taxe sur le combustible nucléaire," LeMonde.fr, 27 May 2011, Eureka.cc.

LeMonde.fr with Agence France-Presse (AFP). "Berlin va accélérer le passage aux énergies renouvelables," LeMonde.fr, 18 March 2011, Eureka.cc.

LeMonde.fr with Agence France-Presse (AFP). "Centrales nucléaires : des tests de sécurité moins ambitieux," LeMonde.fr, 4 May 2011, Eureka.cc.

LeMonde.fr with Agence France-Presse (AFP). "Crise nucléaire au Japon : Obama réitère son soutien et compte envoyer des robots," LeMonde.fr, 30 March 2011, Eureka.cc.

LeMonde.fr with Agence France-Presse (AFP). "Des milliers de manifestants demandent l'arrêt de la centrale de Fessenheim," LeMonde.fr, 11 April 2011, Eureka.cc.

LeMonde.fr with Agence France-Presse (AFP). "Guido Westerwelle quitte la tête du Parti libéral," LeMonde.fr, 4 April 2011, Eureka.cc.

LeMonde.fr with Agence France-Presse (AFP). "L'allemand RWE porte plainte contre l'arrêt d'un de ses réacteurs par Berlin," LeMonde.fr, 1 April 2011, Eureka.cc. 
LeMonde.fr with Agence France-Presse (AFP)."L'augmentation de capital d'Areva repoussée," LeMonde.fr , 22 March 2011, Eureka.cc.

LeMonde.fr with Agence France-Presse (AFP). "L'Etat arbitre en faveur d'EDF sur le prix de l'électricité," LeMonde.fr, 19 April 2011, Eureka.cc.

LeMonde.fr with Agence France-Presse (AFP). "L'usine Areva de la Hague a sousdéclaré plusieurs de ses incidents," LeMonde.fr , 20 May 2011, Eureka.cc.

LeMonde.fr with Agence France-Presse (AFP). "La Commission de régulation de l'énergie refuse d'entériner le prix de l'énergie," LeMonde.fr, 18 May 2011, Eureka.cc.

LeMonde.fr with Agence France-Presse (AFP). "Le conseil municipal de Strasbourg pour la fermeture de la centrale de Fessenheim," LeMonde.fr, 13 April 2011, Eureka.cc.

LeMonde.fr with Agence France-Presse (AFP). "Le FN contre les manipulations des "Cassandre anti-nucléaires"," LeMonde.fr, 15 March 2011, Eureka.cc.

LeMonde.fr with Agence France-Presse (AFP). "Le PS veut élargir le champ d'investigation de l'Autorité de sûreté nucléaire," LeMonde.fr, 10 April 2011, Eureka.cc.

LeMonde.fr with Agence France-Presse (AFP). "Le rapport Roussely préconise un groupement d'intérêt économique des grands acteurs du nucléaire français," LeMonde.fr, 22 March 2011, Eureka.cc.

LeMonde.fr with Agence France-Presse (AFP). "Les anti-nucléaires donnent de la voix après l'accident de Fukushima," LeMonde.fr, 14 March 2011, Eureka.cc.

LeMonde.fr with Agence France-Presse (AFP). "Les géants de l'énergie allemande contre le moratoire sur le nucléaire," LeMonde.fr, 2 April 2011, Eureka.cc.

LeMonde.fr with Agence France-Presse (AFP). "'Les heures qui viennent seront essentielles"," LeMonde.fr, 17 March 2011, Eureka.cc.

LeMonde.fr with Agence France-Presse (AFP). "L'UE parvient à un accord sur les "stress test" des centrales nucléaires," LeMonde.fr, 25 May 2011, Eureka.cc.

LeMonde.fr with Agence France-Presse (AFP). "Manifestations pour la sortie du nucléaire en France et en Allemagne," LeMonde.fr, 26 April 2011, Eureka.cc.

LeMonde.fr with Agence France-Presse (AFP). "Nicolas Hulot se rallie à la sortie du nucléaire," LeMonde.fr, 25 April 2011, Eureka.cc. 
LeMonde.fr with Agence France-Presse (AFP). "Nicolas Sarkozy égratigne la sortie du nucléaire allemande," LeMonde. fr, 8 June 2011, Eureka.cc.

LeMonde.fr with Agence France-Presse (AFP). "NKM pourrait ne pas prolonger la durée de vie des centrales nucléaires françaises," LeMonde.fr, 20 March 2011, Eureka.cc.

LeMonde.fr with Agence France-Presse (AFP). "Nucléaire : pour Eric Besson, la France "n'est pas isolée"," LeMonde.fr, 31 May 2011, Eureka.cc.

LeMonde.fr with Agence France-Presse (AFP). "Pour Anne Lauvergeon, l'arrêt du nucléaire allemand est "politique"," LeMonde.fr, 30 May 2011, Eureka.cc.

LeMonde.fr with Agence France-Presse (AFP). "Pour le président d'EDF, les centrales nucléaires françaises sont en bon état," LeMonde.fr, 18 April 2011, Eureka.cc.

LeMonde.fr with Agence France-Presse (AFP). "Prix de l'électricité : EDF voudrait des hausses de plus de $5 \%$ par an sur cinq ans," LeMonde.fr, 23 March 2011, Eureka.cc.

Le Monde.fr with Agence France-Presse (AFP). "Ségolène Royal fait de la résistance sur le photovoltaïque," Le Monde.fr, 11 March 2011, Eureka.cc.

LeMonde.fr with Agence France-Presse (AFP), "Six Français sur 10 souhaitent sortir du nucléaire," LeMonde.fr, 5 June 2011, Eureka.cc.

LeMonde.fr with Agence France-Presse (AFP). "Sortie du nucléaire : la décision allemande provoque espoir et inquiétudes en France," LeMonde.fr , 31 May 2011, Eureka.cc.

LeMonde.fr with Agence France-Presse (AFP). "Tchernobyl : la cour d'appel examine un arrêt de l'enquête en France," LeMonde.fr, 31 March 2011, Eureka.cc.

LeMonde.fr with Agence France-Presse (AFP) and Reuters."A Tokyo, Sarkozy plaide pour des normes internationales de sécurité nucléaire," LeMonde.fr, 1 April 2011, Eureka.cc.

LeMonde.fr with Agence France-Presse (AFP) and Reuters. "Areva prêt à réfléchir à une introduction en Bourse," LeMonde.fr, 22 March 2011, Eureka.cc.

LeMonde.fr with Agence France-Presse (AFP) and Reuters. "En direct : nouvelle explosion à l'usine de Fukushima," LeMonde.fr, 14 March 2011, Eureka.cc.

LeMonde.fr with Agence France-Presse (AFP) and Reuters. "Japon : des radiations "extrêmement fortes" à Fukushima," LeMonde.fr, 17 March 2011, Eureka.cc. 
LeMonde.fr with Agence France-Presse (AFP) and Reuters. "Japon : désolation à Fukushima, inquiétude à Tokyo," LeMonde.fr, 16 March 2011, Eureka.cc.

LeMonde.fr with Agence France-Presse (AFP) and Reuters. "Japon : scènes de désolation au lendemain du séisme," LeMonde.fr, 12 March, Eureka.cc.

LeMonde.fr with Agence France-Presse (AFP) and Reuters. "Nucléaire, pouvoir d'achat... Sarkozy critique le programme du PS," LeMonde.fr, 8 April 2011, Eureka.cc.

LeMonde.fr with Agence France-Presse (AFP) and Reuters. "Sarkozy accepte un audit sur le "coût réel" du nucléaire en France," LeMonde.fr, 3 May 2011, Eureka.cc.

LeMonde.fr with Agence France-Presse (AFP) and Reuters. "Sarkozy en visite à Tokyo pour exprimer sa "solidarité"," LeMonde.fr, 31 March 2011, Eureka.cc.

LeMonde.fr with Agence France-Presse (AFP) and Reuters. "Sarkozy promet de fermer les centrales nucléaires qui échoueraient aux tests," LeMonde.fr, 26 March 2011, Eureka.cc.

LeMonde.fr with Reuters. "Anne Lauvergeon serait remplacée par Luc Oursel à la tête d'Areva," LeMonde.fr, 17 June 2011, Eureka.cc.

LeMonde.fr with Reuters. "En Alsace, le sort de la centrale de Fessenheim mobilise les élus," LeMonde.fr, 16 April 2011, Eureka.cc.

LeMonde.fr with Reuters and Agence France-Presse (AFP). "Le gouvernement promet un tarif d'électricité regale," LeMonde.fr, 20 April 2011, Eureka.cc.

Leparmentier, Arnaud. "La crise nucléaire japonaise relance le débat sur l'atome en France," Le Monde, 15 March 2011, Eureka.cc.

"Les anti-nucléaires défilent," LeMonde.fr, 26 April 2011, Eureka.cc.

"Les côtes japonaises frappées par un tsunami," Le Monde.fr, 12 March 2011, Eureka.cc.

Lhomme, Stéphane. "Crise nucléaire : le gouvernement français victime du « syndrome MAM," Le Monde, 15 March 2011, Eureka.cc.

Lossau, Norbert. "Nichts ist unmöglich," Die Welt, 8 April 2011, Factiva.

"Machtwechsel in Baden-Württemberg; Ein Grüner wird Ministerpräsident; Winfried Kretschmann will Koalition mit der SPD bilden / Wahlverlierer Mappus: Bitterer Tag für die CDU," Süddeutsche Zeitung, 28 March 2011, Factiva. 
Mamère, Noël. "Est-ce indécent de demander un débat public sur la sortie du nucléaire?" LeMonde.fr, 23 March 2011, Eureka.cc.

“Mängel in US-Reaktoren,” Süddeutsche Zeitung, 14 May 2011, Factiva.

Mary, Catherine. "Confisquer le débat sur les enjeux de la science, c'est affaiblir la démocratie," LeMonde.fr , 9 June 2011, Eureka.cc.

Matern, Tobias. "Fester Glaube; Indiens Energiehunger ist groß, das Land will mit ausländischer Hilfe etliche neue Kernkraftwerke bauen," Süddeutsche Zeitung, 18 March 2011, Factiva.

Maurisse, Marie. "En Suisse, la sortie de l'atome alourdira la facture d'électricité," Le Figaro, 30 May 2011, Factiva.

Mayr, Stefan. "Atomdebatte beschert Grünen großen Zulauf; Die Partei registriert täglich 25 bis 30 neue Mitglieder, auch der schwäbische JU-Bezirkschef wechselt die Seiten," Süddeutsche Zeitung, 24 March 2011, Factiva.

Mennessier, Marc. "Fukushima : la situation serait plus grave que prévu," Le Figaro, 18 May 2011, Factiva.

"Merkel zur Katastrophe in Japan; "Nicht zur Tagesordnung übergehen"," Süddeutsche Zeitung Online, 12 March 2011, Factiva.

Meunier, Castelain Christine and Francis Miller, "Combattre la dette écologique pour s'affranchir des technologies à haut risqué," LeMonde.fr, 31 March 2011, Eureka.cc.

Meyer, Michael G. ""Wir sind alle gesund" - So wie heute die Verantwortlichen in Fukushima verschleierten vor 25 Jahren die Behörden das Ausmaß der Kernschmelze in Tschernobyl," Berliner Zeitung, 26 April 2011, Factiva.

Mignard, Jean-Pierre, Raphael Romi, Sébastien Mabile, and Michel Mabile. "Le nucléaire est un bien public mondial," LeMonde.fr, 18 March 2011, Eureka.cc.

Montebourg, Arnaud. ""Le nucléaire est dépassable"," LeMonde.fr, 14 April 2011, Eureka.cc.

Morin, Hervé. "Menace nucléaire au Japon : Les caractéristiques du réacteur de Fukushima no 1," Le Monde, 14 March 2011, Eureka.cc.

"Nachlese: Landtagswahl in Sachsen-Anhalt; CDU und SPD umgarnen sich," Süddeutsche Zeitung Online, 20 March 2011, Factiva. 
"Naturkatastrophe; Tsunami an Japans Küste," Süddeutsche Zeitung Online, 11 March 2011, Factiva.

Nodé-Langlois, Fabrice. "L'avenir du nucléaire civil en suspens," Le Figaro, 28 March 2011, Factiva.

Nodé-Langlois, Fabrice. "Nucléaire : Merkel avance à 2015 les prochaines fermetures," Le Figaro, 7 June 2011, Factiva.

“Nucléaire : rétablissons quelques verities," LeMonde.fr, 6 May 2011, Eureka.cc.

Oldag, Andreas. "Ärger mit Angela; Großbritanniens Energieminister Chris Huhne verteidigt seine Pro-Atom-Linie - und will sich weder von Berlin noch von Brüssel etwas vorschreiben lassen," Süddeutsche Zeitung, 18 March 2011, Factiva.

Orphelin, Matthieu. "Pour une tarification écologique et solidaire de l'énergie," LeMonde.fr, 31 March 2011, Eureka.cc.

"Ostermarsch am Karsamstag; Atomenergie im Mittelpunkt: „Kein Tschernobyl vor unserer Haustür","Süddeutsche Zeitung , 23 April 2011, Factiva.

“Papier de verre," LeMonde.fr, 16 March 2011, Eureka.cc.

“Papier de verre," LeMonde.fr, 17 March 2011, Eureka.cc.

Parkin, Brian and Nicholas Comfort. "Merkel Proposes 12-Year Nuclear Reactor Extension," Bloomberg, 6 September 2010. Retrieved from http://www.bloomberg.com/news/2010-09-05/merkel-coalition-proposes-12-yearnuclear-reactor-extension-for-germany.html on 23 January 2013.

“Peking bremst," Süddeutsche Zeitung, 17 March 2011, Factiva.

Pfanner, Eric. "Gloves Off in German Media Scramble," 13 March 2011, New York Times. Retrieved from http://www.nytimes.com/2011/03/14/business/global/ 14bild.html?pagewanted=all on 12 March 2013

Piquard, Alexandre. "Hamon (PS) : "On ne peut pas sortir du nucléaire du jour au lendemain,"' LeMonde.fr, 15 March 2011, Eureka.cc.

Piquard, Alexandre. "Japon : comment le discours du gouvernement français a évolué," LeMonde.fr, 15 March 2011, Eureka.cc.

Pouchard, Alexandre. "Nicolas Hulot, du petit écran à la candidature," LeMonde.fr, 13 April 2011, Eureka.cc. 
Prantl, Heribert. "Klingeling, hier kommt die Kanzlerin; Glaubwürdigkeits-Katastrophe: Warum der CDU-Wahlkampf an die alemannische Fastnacht erinnert," Süddeutsche Zeitung, 25 March 2011, Factiva.

Pressekonferenz zum Energiekonzept der Bundesregierung mit Bundeskanzlerin Merkel, BM Rösler, BM Röttgen und BM Ramsauer. 30 May 2011. Retrieved from http://www.bundeskanzlerin.de/Content/DE/Mitschrift/Pressekonferenzen/2011/0 5/2011-05-30-pk-bk-bm-energiekonzept.html on 21 January 2012.

"Protest gegen Atomkraft; "Fukushima mahnt"," Süddeutsche Zeitung Online, 26 March 2011, Factiva.

"Protokoll; "Das Schlimmste, was ich je erlebt habe"," Süddeutsche Zeitung Online, 11 March 2011, Factiva.

"'Quand on vit près d'une centrale nucléaire, on vit avec le risque"," LeMonde.fr, 16 March 2011, Eureka.cc.

“Quel rôle pour Areva dans le sauvetage de Fukushima ?" LeMonde.fr, 30 March 2011, Eureka.cc.

Ramelsberger, Annette. "Kommentar; Atom-Paulus, Öko-Saulus," Süddeutsche Zeitung, 18 March 2011, Factiva.

"Reaktionen nach der Wahl; "Schwarz-Gelb ist abgewählt"," Süddeutsche Zeitung Online, 27 March 2011, Factiva.

"Regierung setzt Laufzeitverlängerung aus; Kehrtwende in der deutschen Atompolitik; Die Kernkraftwerke Isar 1, Biblis A und Neckarwestheim I könnten demnächst abgeschaltet warden," Süddeutsche Zeitung, 15 March 2011, Factiva.

"Renaissance der Ostermärsche - Demonstranten wenden sich gegen Atomkraft, Militäreinsätze und Rüstung," Berliner Zeitung, 26 April 2011, Factiva.

Ricard, Philippe. "L'UE débat de la sûreté de ses centrales nucléaires," LeMonde.fr, 25 March 2011, Eureka.cc.

Riehl, Katharina. "Erdbeben und Internet; Hilfe, Japan, melde dich," Süddeutsche Zeitung Online, 11 March 2011, Factiva.

"Risikofaktor Mensch; Probleme der Atomnutzung sind auch durch bessere Technik nicht zu lösen," Süddeutsche Zeitung, 13 May 2011, Factiva.

Rubner, Jeanne. "Angst vor Westwind; Im französischen Fessenheim, direkt an der Grenze, steht eine altersschwache Atomanlage. Aber weder dort noch im Rest des 
Landes zweifeln die Menschen an der Kernkraft," Süddeutsche Zeitung, 31 March 2011, Factiva.

Rubner, Jeanne. "Außer Kontrolle; Die Verflechtung zwischen Behörden und Atomfirmen trägt zu der bedrohlichen Lage in Japan bei," Süddeutsche Zeitung, 29 March 2011, Factiva.

Rubner, Jeanne. "Überflüssige Brückentechnik; Offener Brief von Wissenschaftlern," Süddeutsche Zeitung, 1 April 2011, Factiva.

Saint-Paul, Patrick. "En Allemagne, la vague verte balaye les conservateurs," Le Figaro, 24 May 2011, Factiva.

Saint-Paul, Patrick. "Énergie nucléaire : le virage de Merkel irrite ses allies," Le Figaro, 5 May 2011, Factiva.

Saint-Paul, Patrick. "L'Allemagne a fait faux bond à l'ONU pour des raisons électorales," Le Figaro, 19 March 2011, Factiva.

Saint-Paul, Patrick. "L'Allemagne se convertit à l'écologie," Le Figaro, 20 April 2011, Factiva.

Saint-Paul, Patrick. "L'indispensable proximité franco-allemande," Le Figaro, 18 June 2011, Factiva.

Saint-Paul, Patrick. "La " neutralité » allemande irrite les allies," Le Figaro, 14 April 2011, Factiva.

Saint-Paul, Patrick. "Le flirt de Merkel avec les Verts agace ses alliés libéraux," Le Figaro, 16 June 2011, Factiva.

Saint-Paul, Patrick. "Les Verts en tête des sondages en Allemagne," Le Figaro, 8 April 2011, Factiva.

Saint-Paul, Patrick. "Les Verts infligent un camouflet à Angela Merkel," Le Figaro, 28 March 2011, Factiva.

Saint-Paul, Patrick. "Nucléaire : les Länder font de la résistance," Le Figaro, 2 June 2011, Factiva.

"Sarkozy : la France restera nucléaire Le chef de l'Etat a dit hier qu'il n'était "évidemment pas question de sortir du nucléaire" pour la France, qui a le parc " le plus sécurisé" et le plus important de l'UE, avec," LeMonde.fr, 15 March 2011, Eureka.cc.

"Sarkozy : sortir du nucléaire reviendrait à "se couper un bras"," LeMonde.fr, 23 April 2011, Eureka.cc. 
"Sarkozy als Stromverkäufer," Süddeutsche Zeitung, 8 June 2011, Factiva.

"Sarkozy convaincu de la "pertinence" du nucléaire pour la France," LeMonde.fr, 17 March 2011, Eureka.cc.

Scharnitzky, Ralf. "Ein bisschen Ausstieg; Wirtschaftsminister Zeil sieht bei einem raschen Abschalten der Atomkraftwerke den Industriestandort gefährdet," Süddeutsche Zeitung, 1 April 2011, Factiva.

Schlandt, Jakob. "Deutschland fast atomstromfrei - Nur sechs von 17 Meilern am Netz und es gibt kein Problem," Berliner Zeitung, 5 May 2011, Factiva.

Schlandt, Jakob. "Konzernumbau - Die Ökopartei kontrolliert jetzt den Atom-Dinosaurier EnBW," Berliner Zeitung, 29 March 2011, Factiva.

Schlandt, Jakob. "Kosten - "Die Konzerne Müssen Bezahlen" - Atomausstieg - Bis zum Jahr 2022 sollen alle Deutschen Kernkraftwerke vom Netz gehen. - 17 Kontaminierte Großanlagen müssen verschwinden. Es wird das Teuerste Abrissprogramm der Deutschen Geschichte," Berliner Zeitung, 14 June 2011, Factiva.

Schlandt, Jakob. "Studie - Wind- und Wasserkraft am billigsten," Berliner Zeitung, 18 April 2011, Factiva.

Schmid, Thomas. "Ausnahmezustand, nein danke," Die Welt, 5 April 2011, Factiva.

Schmid, Thomas. "So wird die deutsche Demokratie ruiniert," Die Welt, 31 May 2011, Factiva.

Schmid, Thomas. "Tollkühner Ausstieg," Die Welt, 6 June 2011, Factiva.

Schrader, Christopher. "Fukushima bleibt auf Monate gefährlich; Rettungskräfte können Strahlungslecks nicht stopfen / Merkel wirbt für breiten Konsens bei Energiewende," Süddeutsche Zeitung, 4 April 2011, Factiva.

Schrader, Christopher. "Kurzschlüsse, Blitze und Flugzeugabstürze; Von den 17 verbleibenden Reaktoren in Deutschland haben die acht ältesten eine schlechtere Pannenstatistik und geringere Sicherheitsreserven," Süddeutsche Zeitung, 14 March 2011, Factiva.

Schrader, Christopher. "Super-GAU im AKW Fukushima; "Die Kernschmelze ist nicht mehr zu stoppen, wenn ..." Süddeutsche Zeitung Online, 12 March 2011, Factiva.

Schwartzbrod, Alexandra. "Le nucléaire français à l'ère du soupcon," Libération, 11 May 2011, Factiva. 
Sebald, Christian. "Draußen vor dem Tor; Die Schauspielerin Mira Neumeier organisiert seit September wöchentliche Mahnwachen vor Isar 1- die Resonanz ist groß," Süddeutsche Zeitung, 21 March 2011, Factiva.

Sebald, Christian and Mike Szymanski. "Christliche Salto-Union; Die CSU wirft über Nacht ihre Atompolitik über Bord: Isar 1 wird abgeschaltet - kein Problem, sagt der Betreiber Eon, es gebe genügend andere Kraftwerke," Süddeutsche Zeitung, 16 March 2011, Factiva.

Sievers, Markus. "Merkel will Atom-Konzerne schonen - Kanzleramt plant, Brennelementesteue $r$ für AKW-Betreiber zu streichen / Widerspruch aus der FDP / Umweltbundesamt: Ausstieg bis 2017 möglich / EU einig über Sicherheitstests," Berliner Zeitung, 26 May 2011, Factiva.

Sievers, Markus and Jakob Schlandt. "Eon klagt gegen Brennelemente-Steuer - Länder fordern Änderungen am Atom-Kompromiss," Berliner Zeitung, 1 June 2011, Factiva.

Slama, Alain-Gérard. "Le coût de la non-Europe," Le Figaro, 8 June 2011, Factiva.

Slavik, Angelika. "Flucht in Wind und Sonne; Deutsche entdecken ihre große Liebe zum Ökostrom," Süddeutsche Zeitung, 17 March 2011, Factiva.

"Söder: Schneller zur erneuerbaren Energie," Süddeutsche Zeitung, 14 March 2011, Factiva.

Solletty, Marion. "Le pire des scénarios : des rejets comparables à Tchernobyl," LeMonde.fr, 17 March 2011, Eureka.cc.

Sommer, Rupert. "TV-Kritik: Anne Will; "Möglichst rascher Ausstieg"," Süddeutsche Zeitung Online, 14 March 2011, Factiva. .

Special Eurobarometer 262: Energy Technologies: Knowledge, Perception, Measures. Published January 2007, with fieldwork May - June 2006. Retrieved from http://ec.europa.eu/public opinion/archives/ebs/ebs 262 en.pdf on 12 February 2013.

Special Eurobarometer 271:Europeans and Nuclear Safety. Published February 2007, October - November 2006. Retrieved from http://ec.europa.eu/public opinion larchives/ebs/ebs 271 en.pdf on 12 February 2013.

Special Eurobarometer 324: Europeans And Nuclear Safety. Published March 2010, with fieldwork September - October 2009. Retrieved from http://ec.europa.ew/energy/ nuclear/safety/doc/2010 eurobarometer safety.pdf on 12 February 2013. 
Strittmatter, Kai. "Es kommt noch besser; Die Türkei will sich Atomkraftwerke bauen lassen. Von den Japanern. Ausgerechnet die Firma Tepco ist gerade in Ankara, um das Geschäft rund zu machen," Süddeutsche Zeitung ,17 March 2011, Factiva.

Stroobants, Jean-Pierre."Désaccord européen sur les stress tests nucléaires," LeMonde.fr , 12 May 2013, Eureka.cc.

Stürmer, Michael. "Keine Vision, nirgends," Die Welt, 11 April 2011, Factiva.

"Sur mesure," LeMonde.fr, 21 March 2011, Eureka.cc.

Szymanski, Mike. "Seehofer legt den Schalter um; Mit aller Kraft zwingt der CSUVorsitzende seine Partei auf den neuen Atomkurs - die Kritiker werden abgekanzelt," Süddeutsche Zeitung, 30 March 2011, Factiva.

Tassel, Stéphane. "Nous devons reconquérir ce qui nous a fait choisir le service public..." LeMonde.fr, 5 May 2011, Eureka.cc.

“Tausende protestieren gegen Kernkraft," Die Welt, 26 April 2011, Factiva.

Tichomirowa, Katja. "Jeder Kreis schützt sich selbst - Der Bund hat im Fall eines Atomunfalls gar nichts zu melden. Die Länder sind allein zuständig," Berliner Zeitung, 2 April 2011, Factiva.

Torry, Harriet. "Another German Minister Felled by Plagiarism Claims," Wall Street Journal Blogs, 11 February 2013. Retrieved from http://blogs.wsj.com/eurocrisis/ 2013/02/11/another-german-minister-felled-by-plagiarism-claims/ on $12 \mathrm{March}$ 2013.

"Tsunami für die Atomlobby; Die Nuklearkatastrophe in Japan wirkt tief auf das Bewusstsein der Menschen in Deutschland - viele wünschen sich einen Ausstieg aus der Kernkraft," Süddeutsche Zeitung, 17 March 2011, Factiva.

"Tsunami-Vorhersage; Kartographie der Katastrophe," Süddeutsche Zeitung Online, 11 March 2011, Factiva.

Ulrich, Stefan. "Die grüne Eminenz tritt an; Der Fernsehstar und Umweltaktivist Nicolas Hulot will in Frankreich für die Präsidentschaft kandidieren," Süddeutsche Zeitung, 9 April 2011, Factiva.

Ulrich, Stefan. "Wankendes Dogma; Kernkraftwerke waren bisher Frankreichs ganzer Stolz - jetzt regen sich ernste Zweifel an der Nuklearwirtschaft," Süddeutsche Zeitung, 18 March 2011, Factiva.

UMP, NC, PS and PC MPs. "Ne pas démanteler Areva," LeMonde.fr, 6 June 2011, Eureka.cc. 
"Unsichtbar und tückisch; Wie Strahlung auf Menschen wirkt," Süddeutsche Zeitung, 14 March 2011, Factiva.

Uterwedde, Henrik. "Allemagne : le pari de l'après-nucléaire," Le Figaro, 3 June 2011, Factiva.

Vates, Daniela. "Aussteigen und hoffen - Die Union tut sich schwer mit ihrem neuen Anti-Atom-Kurs," Berliner Zeitung, 3 May 2011, Factiva.

Vates, Daniela, Markus Sievers, and Damir Fras. "Brüderle wird zum Restrisiko Minister soll AKW-Moratorium mit Wahlkampftaktik begründet haben / Dementi im Parlament / CSU: Glaubwürdigkeit der Union untergraben / Zwist in der Koalition," Berliner Zeitung, 25 March 2011, Factiva.

Visit to Germany - Statements by Nicolas Sarkozy, President of the Republic, at his joint press conference with Angela Merkel, Chancellor of Germany (excerpts), 17 June 2011. Retrieved from http://www.ambafrance-uk.org/President-Sarkozy-spress, 19170 on 18 March 2013.

Vogel, Matthias. "Unter Stromverbrauchern; Eon-Vorstand Johannes Teyssen referiert beim Empfang der Kreishandwerker über seine Sicht der Energiepolitik," Süddeutsche Zeitung, 14 March 2011, Factiva. .

"Vor Koalitionsgipfel; Zehntausende demonstrieren gegen Atomkraft," Süddeutsche Zeitung Online, 28 May 2011, Factiva.

Weiss, Marlene. "Gegen alle Regeln; Japans Atomkraftwerke müssen seit der Katastrophe von Kobe viel aushalten können, aber für ein Erdbeben der Stärke 8,9 waren auch sie nicht gerüstet," Süddeutsche Zeitung, 12 March 2011, Factiva.

Wetzel, Daniel. “AKW-Betreiber wehren sich,” Die Welt, 8 June 2011, Factiva.

Wetzel, Daniel. "Ein teurer Konsens," Die Welt, 16 May 2011, Factiva.

Wetzel, Daniel. “Glücksspiel statt Sicherheit,” Die Welt, 23 May 2011, Factiva.

Wetzel, Daniel. "Kampf gegen den Blackout,” Die Welt, 20 May 2011, Factiva.

Wetzel, Daniel. "Netzbetreiber warnen vor Blackout im Winter," Die Welt, 23 May 2011, Factiva.

Wetzel, Daniel and Carsten Dierig, "Deutschland braucht Atom-Hilfe," Die Welt, 5 April 2011, Factiva. 
Widmann, Amo. "Fürchtet euch! - Die "German Angst" ist wieder da. Sie mag ein lächerliches Gefühl sein, doch selten war sie nützlicher als heute," Berliner Zeitung, 19 March 2011, Factiva.

Wild, Beate. "Anti-Atomkraft-Demo in München; "Abschalten! Abschalten!"," Süddeutsche Zeitung Online, 15 March 2011, Factiva.

Wille, Joachim. "Atomare Zeitenwende," Berliner Zeitung, 18 May 2011, Factiva.

Wille, Joachim. “Atomausstieg im Schleichgang," Berliner Zeitung, 31 May 2011, Factiva.

Wille, Joachim. “Zurück zum Atom-Ausstieg!” Berliner Zeitung, 14 March 2011, Factiva.

Wolff, Verena. "Atomkatastrophe in Japan: Die Kosten; Wer soll das alles zahlen?" Süddeutsche Zeitung Online, 16 March 2011, Factiva.

Yanukovych, Viktor. "Nucléaire : un seul monde, une seule sécurité," Le Figaro, 19 April 2011, Factiva.

"Zehntausende protestieren gegen Atomkraft; Anti-AKW-Bewegung und Friedensaktivisten zeigen ihren Unmut über die Bundesregierung / Kirchen fordern solidarischen Lebensstil," Süddeutsche Zeitung, 26 April 2011, Factiva.

"Zitate zur Atomdebatte; Hoch lebe die Kernkraft, die Kernkraft muss weg!" Süddeutsche Zeitung Online, 16 March 2011, Factiva.

Zöllner, Reinhard. “Apokalypse jetzt!,” Die Welt, 28 March 2011, Factiva.

Secondary Sources

Allen, Christopher S. and Wade Jacoby. "Germany." In Introduction to Comparative Politics: Political Challenges and Changing Agendas, Sixth Edition, ed. Mark Kesselman, Joel Krieger, and William A. Joseph, 138-187. Wadsworth: Cengage Learning, 2013.

Benford, Robert D. and David A. Snow. "Framing Processes and Social Movements: An Overview and Assessment." Annual Review of Sociology, 26 (2000), 61 1-639.

Elliot, David. Fukushima: Impacts and Implications. Palgrave Macmillian, 2012.

Gamson, William A. and Andre Modigliani. "Media Discourse and Public Opinion on Nuclear Power: A Constructionist Approach." American Journal of Sociology 95, no. 1 (Jul., 1989), 1-37. 
Hecht, Gabrielle. Radiance of France : Nuclear Power and National Identity after World War II. Cambridge, MA: MIT Press, 2009.

Jasper, James M. Nuclear Politics: Energy and the State in the United States, Sweden, and France. Princeton: Princeton University Press, 1990.

Joppke, Christian. "Social Movements during Cycles of Issue Attention: The Decline of the Anti-Nuclear Energy Movements in West Germany and the USA." British Journal of Sociology 42, no. 1 (Mar., 1991), 43-60.

Kesselman, Mark. "France." In Introduction to Comparative Politics: Political Challenges and Changing Agendas, Sixth Edition, ed. Mark Kesselman, Joel Krieger, and William A. Joseph, 90-137. Wadsworth: Cengage Learning, 2013.

Kolb, Felix. Protest and Opportunities: The Political Outcomes of Social Movements. Chicago: University of Chicago Press, 2007.

Koopmans, Ruud and Jan Willem Duyvendak. "The Political Construction of the Nuclear Energy Issue and Its Impact on the Mobilization of Anti-Nuclear Movements in Western Europe." Social Problems 42, no. 2 (May 1995), 235-251.

Nelkin, Dorothy and Michael Pollak. The Atom Besieged: Extraparliamentary Dissent in France and Germany. Cambridge, Massachusetts: MIT Press, 1981.

Nelkin, Dorothy and Michael Pollak. "Political Parties and the Nuclear Energy Debate in France and Germany." Comparative Politics 12, no. 2 (January 1980), 127-141.

Thomas, S.D. The Realities of Nuclear Power: International Economic and Regulatory Experience. Cambridge: Cambridge University Press, 2009.

Wagner, Peter. "Contesting Policies and Redefining the State: Energy Policy-making and the Anti-nuclear Movement in West Germany." In States and Anti-Nuclear Movements, ed. Helena Flam, 264-295. Edinburgh: Edinburgh University Press, 1994.

Wittneben, B.B.F. "The impact of the Fukushima nuclear accident on European energy policy." Environmental Science \& Policy 15 (2012), 1-3. 